Florida International University FIU Digital Commons

$11-12-2009$

\title{
Estimation of Ravine Sediment Production and Sediment Dynamics in the Lower Le Sueur River Watershed, Minnesota
}

Luam A. Azmera

Florida International University, lazme001@fiu.edu

DOI: $10.25148 /$ etd.FI09121605

Follow this and additional works at: https://digitalcommons.fiu.edu/etd

\section{Recommended Citation}

Azmera, Luam A., "Estimation of Ravine Sediment Production and Sediment Dynamics in the Lower Le Sueur River Watershed, Minnesota" (2009). FIU Electronic Theses and Dissertations. 142.

https://digitalcommons.fiu.edu/etd/142 


\section{FLORIDA INTERNATIONAL UNIVERSITY}

Miami, Florida

ESTIMATION OF RAVINE SEDIMENT PRODUCTION AND SEDIMENT

DYNAMICS IN THE LOWER LE SUEUR RIVER WATERSHED, MINNESOTA

A thesis submitted in partial fulfillment of the

requirements for the degree of

MASTER OF SCIENCE

in

CIVIL ENGINEERING

by

Luam Amir Azmera

2009 
To: Dean Amir Mirmiran

College of Engineering and Computing

This thesis, written by Luam Amir Azmera, and entitled Estimation of Ravine Sediment production and Sediment Dynamics, in the lower Le Sueur River watershed, Minnesota, having been approved in respect to style and intellectual content, is referred to you for judgment.

We have read this thesis and recommend that it be approved.

Hector R. Fuentes

Assefa M. Melesse, Co-Major Profesor

Fernando R. Miralles-Wilhelm , Co-Major Professor

Date of Defense: November 12, 2009

The thesis of Luam Amir Azmera is approved.

Dean Amir Mirmiran

College of Engineering and Computing

Dean George Walker

University Graduate School 


\section{ACKNOWLEDGMENTS}

I wish here to express my sincere appreciation to my major advisor Dr. Fernando R. Miralles-Wilhelm, at Department of Civil \& Environmental Engineering for his guidance, generous support, and the time he took to shape me into a better engineer during the past two years. I would also like to recognize the other members of my committee, Dr. Hector R. Fuentes and my co-advisor Dr. Assefa M. Melesse for their constructive ideas that shaped my thesis into structured research. My special thanks go to Dr. Reinaldo Garcia without the endless guidance and knowledge he had offered me, my thesis wouldn't had got into fruition. I would like to acknowledge the Le Sueur River research team especially Dr. Patrick Belmont for his valuable comments in my research and Dr. Carrie Jennings and Ashley Thomas who worked together with me to collect data in the field. I am also grateful to Scott Mateson, Dr. John Thomas and Dr. Dino Torri for providing me the data and information required for my thesis.

I also would like to acknowledge the National Center for Earth-Surface Dynamics (NCED) for funding my field research in summer 2008, and St. Anthony Falls Lab at the University of Minnesota for providing me work space. I would like to thank my fellow officemates and graduate students at the Hydrologic Modeling Lab at Florida International University for their friendship and for making my stay memorable. I can't thank enough my family whose prayers, love and support for me never seized. Finally, I wish to thank Yohannes for loving me unconditionally, encouraging me and giving me the strength when I need it most during the past two years. 


\author{
ABSTRACT OF THE THESIS \\ ESTIMATION OF RAVINE SEDIMENT PRODUCTION AND SEDIMENT \\ DYNAMICS IN THE LOWER LE SUEUR RIVER WATERSHED, MINNESOTA
}

by

Luam Amir Azmera

Florida International University, 2009

Miami, Florida

\title{
Professor Fernando R. Miralles-Wilhelm, Co-Major Professor \\ Professor Assefa M. Melesse, Co-Major Professor
}

This study focuses on quantifying explicitly the sediment budget of deeply incised ravines in the lower Le Sueur River watershed, in southern Minnesota. High-rate-gullyerosion equations along with the Universal Soil Loss Equation (USLE) were implemented in a numerical modeling approach that is based on a time-integration of the sediment balance equations. The model estimates the rates of ravine width and depth change and the amount of sediment periodically flushing from the ravines. Components of the sediment budget of the ravines were simulated with the model and results suggest that the ravine walls are the major sediment source in the ravines. A sensitivity analysis revealed that the erodibility coefficients of the gully bed and wall, the local slope angle and the Manning's coefficient are the key parameters controlling the rate of sediment production. Recommendations to guide further monitoring efforts in the watershed and increased detail modeling approaches are highlighted as a result of this modeling effort. 


\section{TABLE OF CONTENTS}

CHAPTER

PAGE

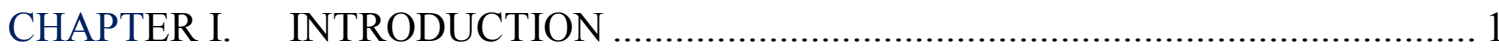

Background: Erosion Problems in the Le Sueur River Watershed........................ 1

Research Questions .................................................................... 8

Specific Objectives and Scope of Research ................................................ 8

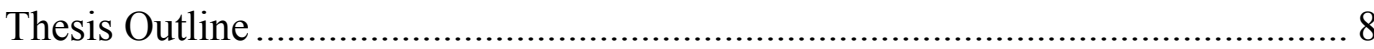

CHAPTER II. LITERATURE REVIEW .......................................................... 10

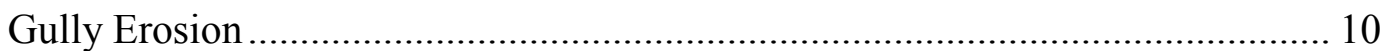

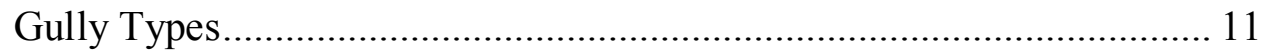

Gully Development ................................................................ 12

Controlling Factors .................................................................. 13

Techniques of Measuring Gully Erosion .......................................................... 13

Gully Erosion and Sediment Transport Models................................................. 15

CHAPTER III. RESEARCH METHODOLOGY .................................................... 20

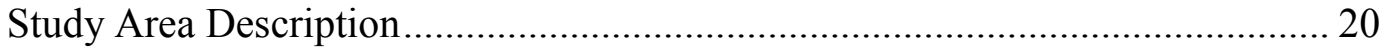

Le Sueur River Watershed Characteristics ............................................. 20

Ravine Characteristics .......................................................................... 21

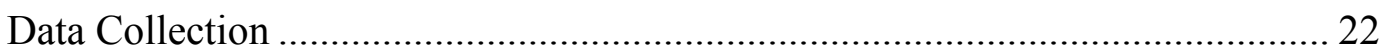

Field Topographic Observations .................................................... 23

Ravine Geometry Estimations ....................................................... 34

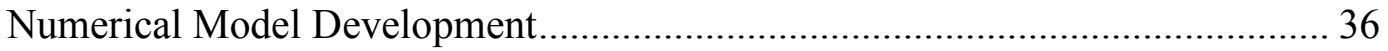

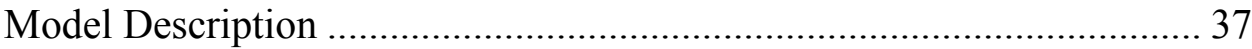

The Universal Soil Loss Equation - USLE .............................................. 40

Governing Equations of Gully Erosion Rate ...................................... 43

Model Assumptions and Limitations ............................................. 49

Characterization of Coefficient of Soil Erodibility.............................. 49 


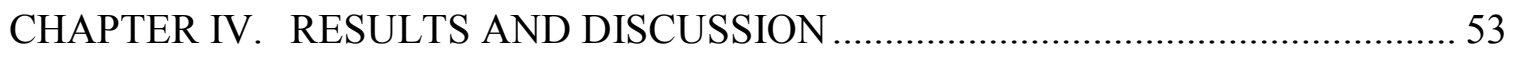

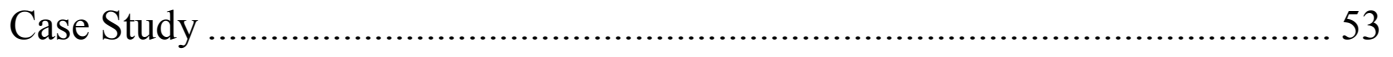

Model Estimations for Study Ravines ......................................................... 58

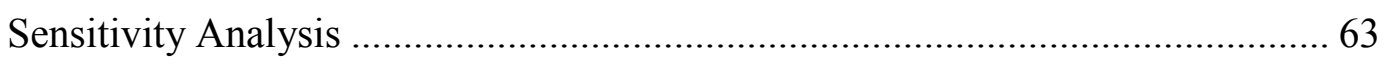

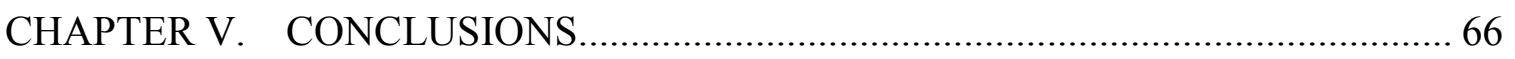

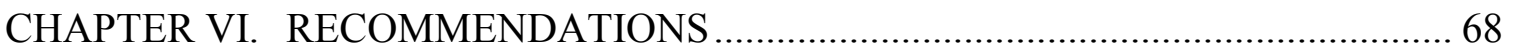

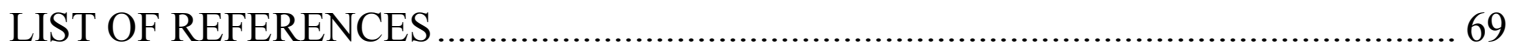

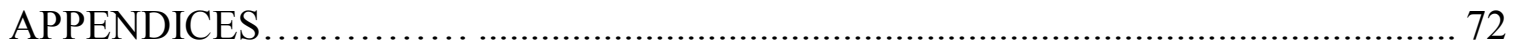




\section{LIST OF TABLES}

TABLE

PAGE

Table 1. Process represented in the models reviewed after Merritt et al. (2003) ............ 16

Table 2. Summary of Ravine morphometric parameters. ............................................ 35

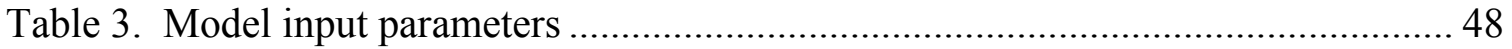

Table 4. Summary of Sediment loading and sediment contribution of sources inside ravines.

Table 5. Parameterization of the erosion model and sensitivity analysis of its parameters. 


\section{LIST OF FIGURES}

FIGURE

PAGE

Figure 1. Geographic location of the Le Sueur River watershed.................................. 4

Figure 2. Sediment sources in lower Le Sueur valley- LiDAR .................................... 5

Figure 3. Illustration landscape features in the lower knick zone of the Le Sueur......... 6

Figure 4. Geographic Location of Study Ravines in the Lower Le Sueur ......

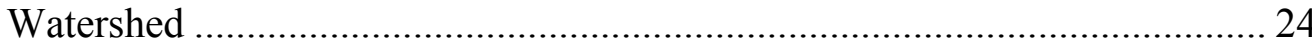

Figure 5. Comparison of TSS measurements in 2008 of the upper and lower

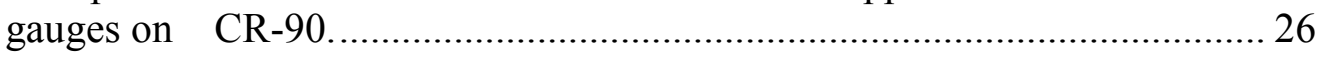

Figure 6. Bluff along the main stem of ravine CR-90. (About 6 meter high) ............. 27

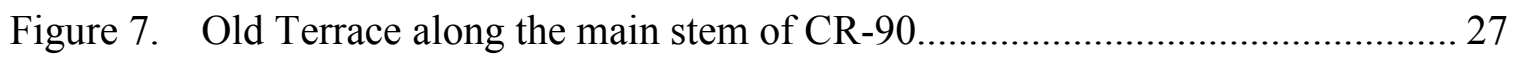

Figure 8. Type of failure of the ravine walls and headcut...................................... 29

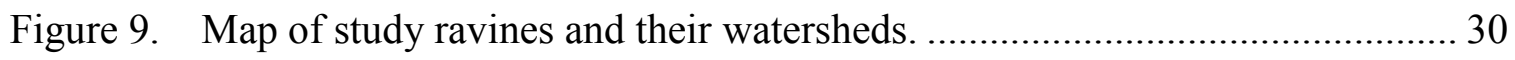

Figure 10. Map of bluffs, terraces, and entry points of concentrated flow.

The concentrated flow comes from overland flow from the agricultural fields and the tile drainage into the ravine............................................... 31

Figure 11. Drainage tiles at the head of a tributary of Ravine CR-90 .......................... 34

Figure 12. Sketch of gully cross-section with sediment sources. ............................... 38

Figure 13. Efficiency coefficient as a function of the ration between channel width and water flow depth based on Chow ( 1973).......................................... 45

Figure 14. Ravine bed sediment load calculation. Using Torri and Borcelli's unit stream power and Meyer-Peters and Muller equations............................. 50

Figure 15. Comparison of the fits of the two equations for estimating sediment load from gully bed....

Figure 16. Comparison of modeled and observed (a) gully width, (b) gully depth and (c) bank slope.

Figure 17. Mean gully width growth over time ................................................... 55

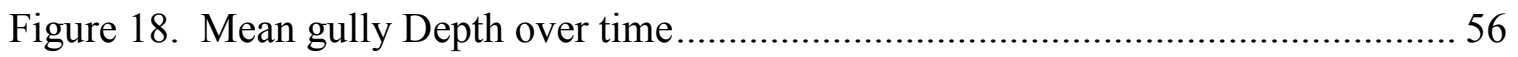




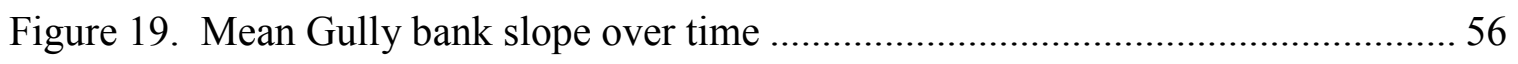

Figure 20. Volumetric growth of gully versus water discharge.................................. 57

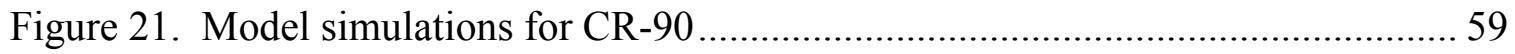

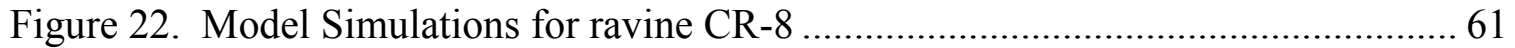




\section{LIST OF SYMBOLS}

\begin{tabular}{|c|c|}
\hline$W$ & Width of gully (m) \\
\hline$D$ & Depth of gully (m) \\
\hline$Q$ & Water flow rate $\left(\mathrm{m}^{3} \mathrm{~s}^{-1}\right)$ \\
\hline$q_{I N}$ & Sediment from upstream per unit of channel length $\left(\mathrm{kg} \mathrm{day}^{-1} \mathrm{~m}^{-1}\right)$ \\
\hline$q_{\text {OUT }}$ & Sediment discharge per unit of channel length $\left(\mathrm{kg} \mathrm{day}^{-1} \mathrm{~m}^{-1}\right)$ \\
\hline$q_{L}$ & Sediment uplands per unit of channel length $\left(\mathrm{kg} \mathrm{day}^{-1} \mathrm{~m}^{-1}\right)$ \\
\hline$q_{S}$ & Sediment from gully banks per unit of channel length $\left(\mathrm{kg} \mathrm{day}^{-1} \mathrm{~m}^{-1}\right)$ \\
\hline$q_{B}$ & Sediment from gully bed per unit of channel length $\left(\mathrm{kg} \mathrm{day}^{-1} \mathrm{~m}^{-1}\right)$ \\
\hline$q_{S E D}$ & Sediment settling in the gully bed per unit of channel length $\left(\mathrm{kg} \mathrm{day}^{-1} \mathrm{~m}^{-1}\right)$ \\
\hline$\Delta Q_{\text {STO }}$ & $\begin{array}{l}\text { Sediment leaving the volume of water } W L h \text { flowing within the gully in a } \\
\text { given time interval }\left(\mathrm{kg} \mathrm{day}^{-1}\right)\end{array}$ \\
\hline$Q_{I N}$ & Sediment from upstream inflow $\left(\mathrm{kg} \mathrm{day}^{-1}\right)$ \\
\hline$Q_{\text {OUT }}$ & Sediment leaving the gully $\left(\mathrm{kg} \mathrm{day}^{-1}\right)$ \\
\hline$Q_{L}$ & Sediment from lateral uniform inflow derived from the uplands $\left(\mathrm{kg} \mathrm{day}^{-1}\right)$ \\
\hline$Q_{S}$ & Sediment from gully banks $\left(\mathrm{kg}\right.$ day $\left.^{-1}\right)$ \\
\hline$Q_{B}$ & Sediment from gully bed $\left(\mathrm{kg} \mathrm{day}^{-1}\right)$ \\
\hline$Q_{S E D}$ & Sediment settling in the gully $\left(\mathrm{kg} \mathrm{day}^{-1}\right)$ \\
\hline$\frac{\partial q_{S T O}}{\partial t}$ & Rate of change of suspended sediment in gully $\left(\mathrm{m} \mathrm{day}^{-1}\right)$ \\
\hline$\frac{\partial W}{\partial t}$ & Rate of change of gully width over time $\left(\mathrm{m} \mathrm{day}^{-1}\right)$ \\
\hline$\frac{\partial D}{\partial t}$ & Rate of change of gully depth over time $\left(\mathrm{m} \mathrm{day}^{-1}\right)$ \\
\hline$\frac{\partial D}{\partial W}$ & Rate of change of gully depth with respect to width \\
\hline$\frac{\partial V_{S T O}}{\partial t}$ & Rate of change of stored sediment volume over time $\left(\mathrm{m}^{3}\right.$ day $\left.^{-1}\right)$ \\
\hline
\end{tabular}




$\begin{array}{ll}\rho & \text { Soil bulk density }\left(\mathrm{kg} \mathrm{m}^{-3}\right) \\ \rho_{A} & \text { Water density }\left(\mathrm{kg} \mathrm{m}^{-3}\right) \\ k_{S} & \text { Coefficient of soil erodibility of gully walls }\left(\mathrm{day}^{2} \mathrm{~m}^{-2}\right) \\ k_{B} & \text { Coefficient of soil erodibility of gully bed }\left(\mathrm{day}^{2} \mathrm{~m}^{-2}\right) \\ u_{S E D} & \text { Sedimentation velocity in a turbulent flow }\left(\mathrm{m} \mathrm{s}^{-1}\right) \\ g & \text { Gravity acceleration }\left(\mathrm{m} \mathrm{s}^{-2}\right) \\ p & \text { Flow aggressiveness } \\ p_{c r} & \text { Critical flow aggressiveness } \\ e_{f} & \text { Efficiency coefficient }- \text { the ratio between the force exerted by flow on } \\ \gamma & \text { gully banks and force exerted on the gully bed. } \\ n & \text { Local slope angle }\end{array}$




\section{LIST OF ACRONYMS}

AGNPS

ASCE

CREAMS

DEM

EPA

GIS

GPS

HSPF

LiDAR

MPCA

NSE

$\operatorname{rcbp}$

SedNet

TSS
AGricultural Non-Point Source Pollution Model

American Society of Civil Engineers

Chemicals, Runoff and Erosion from Agricultural Management

Systems

Digital Elevation Model

US Environmental Protection Agency

Geographic Information System

Global Positioning System

Hydrological Simulation Program - FORTRAN

Light Detection And Ranging

Minnesota Pollution Control Agency

Nash-Sutcliffe Efficiency

Radio Carbon Years Before Present

Sediment River Network model

Total Suspended Solids 


\section{CHAPTER I. INTRODUCTION}

\section{Background: Erosion Problems in the Le Sueur River Watershed}

Soil erosion has long been considered to accelerate over the development of human activity in history, particularly agriculture. Soil erosion caused by water has been one of the prominent processes causing reduced soil quality and reduced water-holding capacity of agricultural areas leading to decreased agricultural yield. Soil erosion also has off-site impact on larger spatial scales than the agricultural fields. Sediment yield from agricultural watersheds cause sedimentation in watercourses and reservoirs, damaging engineering structures and rapidly increase water turbidity. Sediments are also carriers of pollutants such as nutrients, pathogens and toxic substances. Increased sediment loading to watercourses and reservoirs had resulted in poor water quality in the United States. According to the U.S Environmental Protection Agency (EPA)'s most recent list, there are about 26,000 impaired water bodies in United States. Sediment and nutrients together are the major concern for approximately 11,000 of these water bodies, thus the most common impairments are sediment related. Soil conservation planning and development of effective sediment control strategies hence are the main constraints in catchment management planning.

Critical to the development of such management systems is the identification of the potentially significant sources and quantifying the sediment yield from each source. The Le Sueur River watershed in Minnesota is one example where the hydrology of the system had been artificially altered for agricultural purposes and its geomorphic characteristics continue to be naturally modified. Large amounts of sediments are being 
produced in this watershed and loading to the Le Sueur River increasing the turbidity of the watercourse. The Le Sueur River is located in the south-central part of the state, (Figure 1). Its watershed is one of the twelve major watersheds of the Minnesota River Basin. According to reports of MPCA (Minnesota Pollution Control Agency), significant stretches of the Le Sueur and Minnesota Rivers are claimed to be turbid under the Clean Water Act. Recent sediment gauging efforts indicate that the Le Sueur River is the primary sediment contributor (24-30\%) of the Minnesota River (2007). The Minnesota River is also one of the major tributaries of the upper Mississippi River, (Figure 1). The Minnesota River contributes $85-90 \%$ of suspended sediment to Lake Pepin (Kelley and Nater 2000). Lake Pepin is a natural impoundment $80 \mathrm{~km}$ downstream of the metropolitan area of Minneapolis - St. Paul along the Mississippi River. Lake Pepin is an important recreational and commercial resource for the region. However, its impaired water quality has recently become a serious concern for pollution control agencies such as MPCA. Analyses of sediment cores in Lake Pepin indicate that sediment loads in the lake have increased 10-fold since the onset of European settlement in the mid -1800 s (Engstrom et al. 1997).

In the Le Sueur and Minnesota Rivers, turbidity levels are high and call for management actions. Understanding the location and magnitude of sediment sources is essential for guiding management decision to reduce sediment loading and improve water quality. A large-scale effort is underway to study the sediment dynamics of the Le Sueur River in an effort to better define the source locations and transport processes of sediment inflowing 
to the Minnesota River. As a first step to quantifying the sediment budget of the river watershed, an effort has been carried out to define the potential sediment source locations. A study by Gran et al.(2008) shows that the major sediment sources to the Le Sueur River are upland-derived sediment, high bluffs, terraces and large permanent gullies - ravines. Figure 2 shows sediment sources on Digital Elevation Model (DEM) of lower Le Sueur valley. Figure 3 depicts the potential sources of sediments in the ravinegully system on the Le Sueur River. 


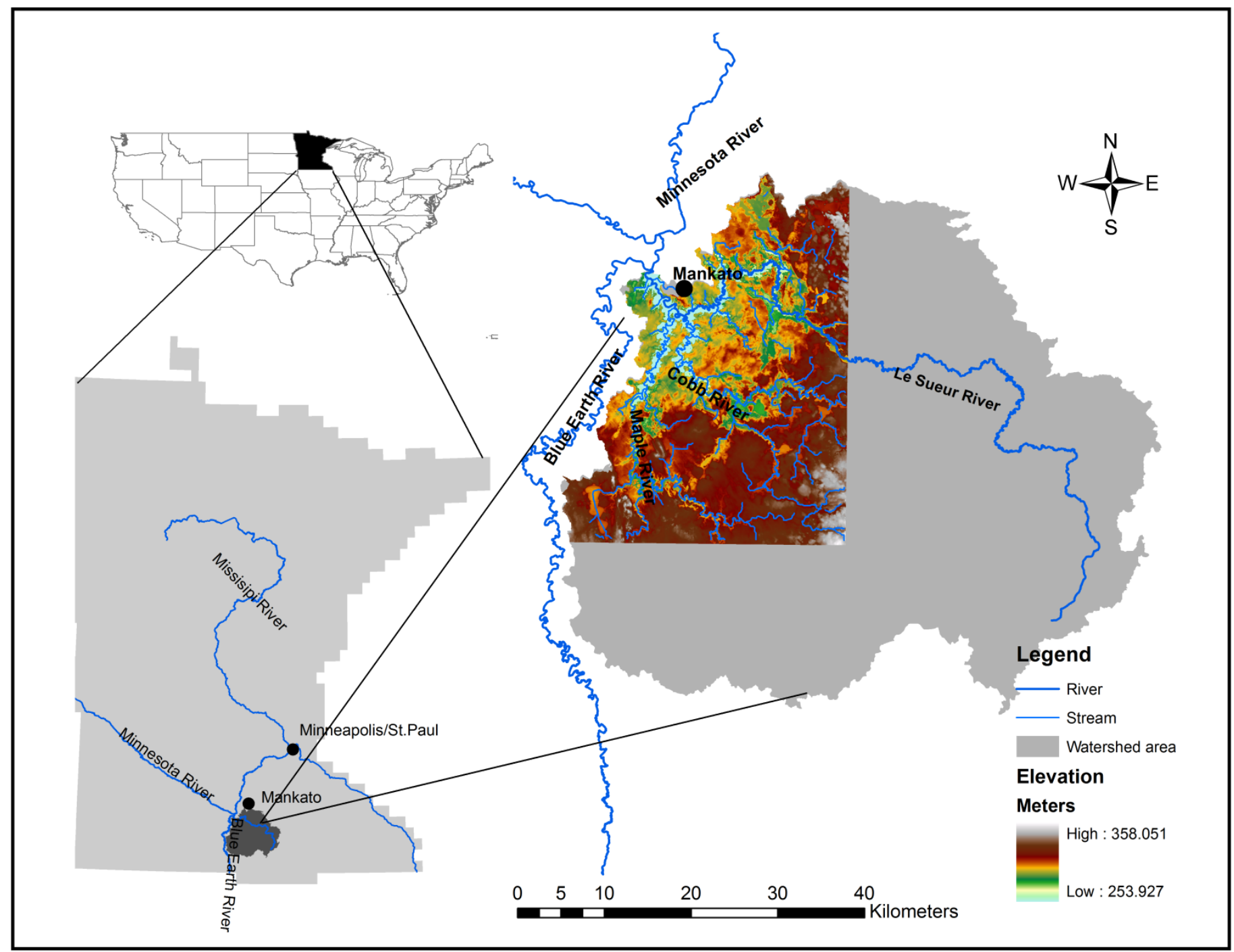

Figure 1. Geographic location of the Le Sueur River watershed 


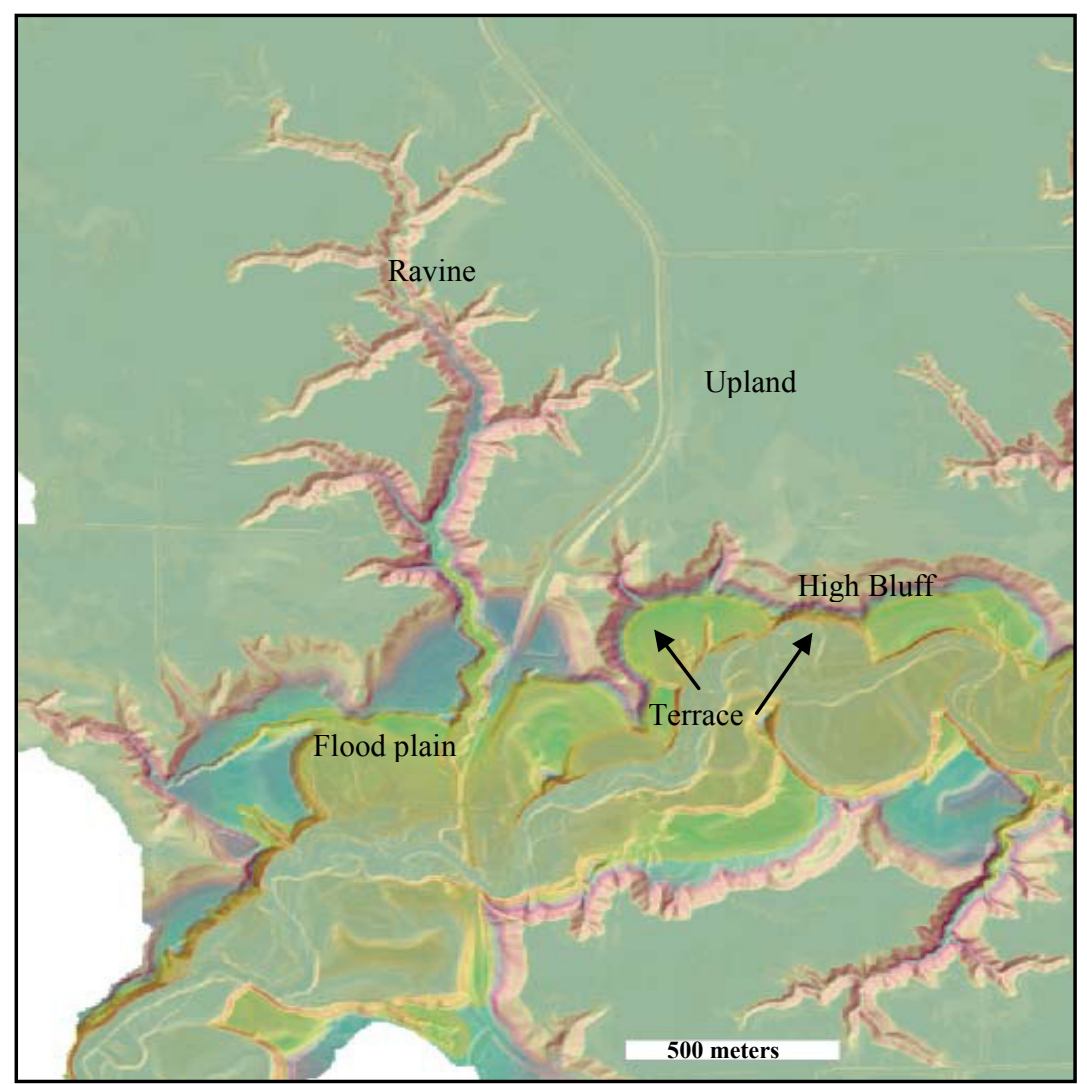

Figure 2. Sediment sources in lower Le Sueur valley LiDAR. Source: Gran et al. (2008)

The next step in understanding the sediment dynamics of the Le Sueur River would be to establish an integrated sediment budget of the river watershed. Once the sediment sources are identified and the sediment budget components are quantified, best management practices can be introduced to reduce the sediment loading. This however needs a refined estimate of sediment produced from each source. The erosion processes in the main three identified sources need to be addressed individually so that the integrated sediment budget would give a better understanding of the sediment dynamics in the watershed. 


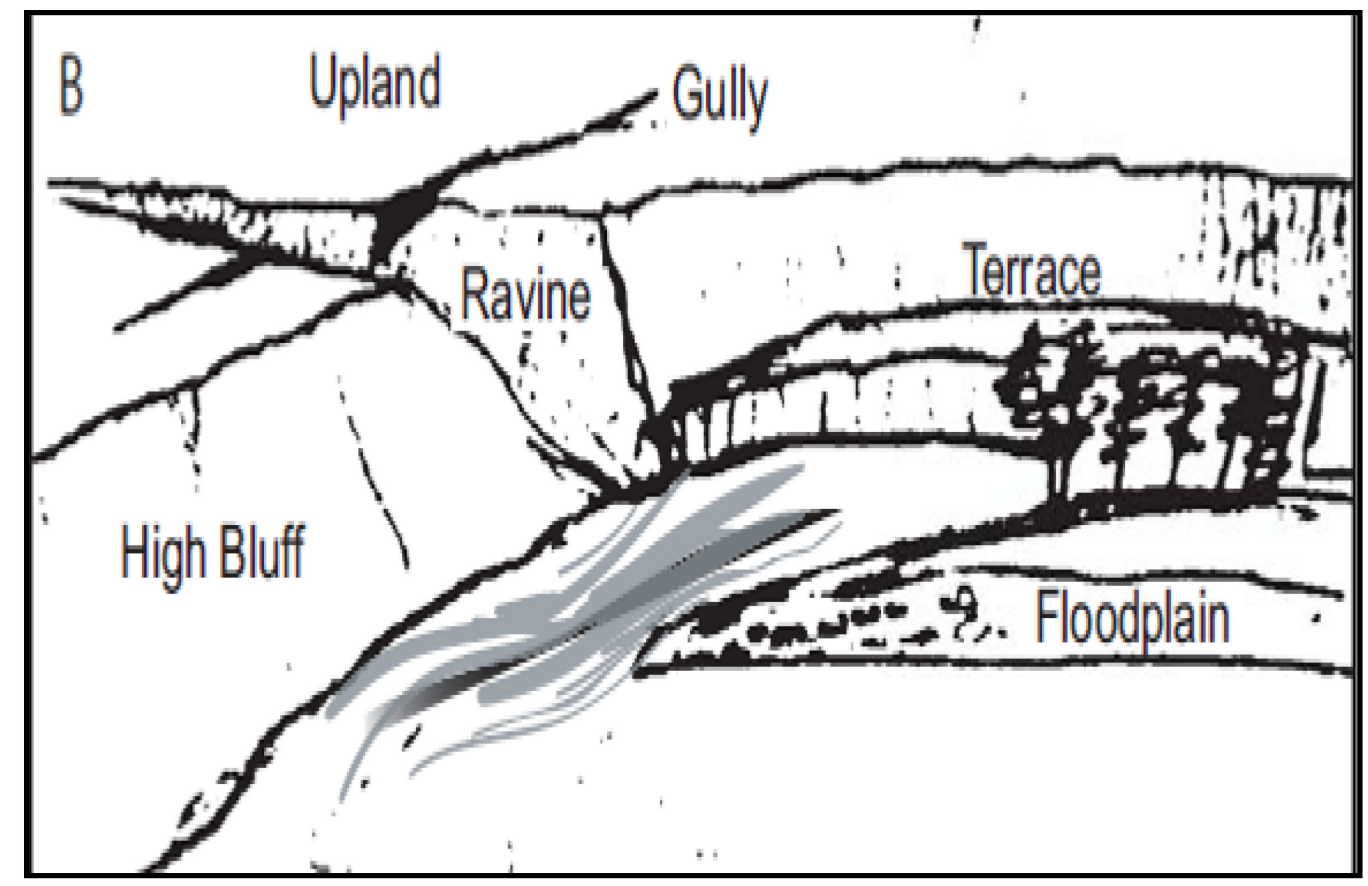

Figure 3. Illustration landscape features in the lower knick zone of the Le Sueur. These features are considered as the major sediment sources in river watershed. (Gran et al. 2008)

Ravine erosion is an important soil erosion process in the Le Sueur River valley, because deeply incised ravines are prevalent features in this part of Minnesota. Although their sediment contribution is believed to be significant, scarce quantitative research on the area of ravine erosion has been done so far in this area. Ravine erosion is not usually accounted in routines schemes for predicting soil loss from watersheds. The development stages, rate of growth and the quantification of the sediment volume produced from ravines is also an important topic in erosion research, however, limited number of erosion and sediment transport models attempt to explicitly describe these processes. This might be because many previous studies dealing with soil erosion by water had concentrated on rill and interill erosion. For this reason, it seemed relevant to undertake a new study of ravine erosion with special attention to quantifying the sediment budget of ravines. 
Permanent gullies are often defined for agricultural land in terms of channels too deep to easily ameliorate with ordinary farm tillage equipment, typically ranging from 0.5 to as much as 25-30 m depth (Soil Science Society of America 2001). Ravines the lower Le Sueur valley have similar geomorphic features as permanent gullies. But the ravines in this area seem to have a deeper and wider valley, they connect relatively larger areas in the landscape, and they have a vegetation cover of dense trees. There is also considerable erosion activity within the ravine valleys which make them a potential major sediment producing source in the Le Sueur River watershed. A more detailed description of the study ravines is given in the following sections of this thesis.

Despite their minor morphological differences, the general theory of sediment dynamics of wide and deep permanent gullies is believed to apply to ravines. Therefore, based on the review of previous studies of gully erosion, this thesis provides a study of the sediment dynamics, and the development of a numerical model to quantify the components of the sediment budget of ravines. Here in after, the term gully refers to ravine in this thesis.

The work documented in this thesis is the culmination of two years work towards a Master of Science and is expected to contribute towards the larger scale research that involves the study of sediment dynamics and development of an integrated sediment budget for the entire Le Sueur River watershed. 


\section{Research Questions}

- What are the sources triggering erosion inside ravines?

- What is the rate of sediment production inside the ravines?

- How is the ravine morphology- depth, width and length changing over time?

\section{$\underline{\text { Specific Objectives and Scope of Research }}$}

Taking into account the ravine sediment contribution, it is believed that a more accurate estimate of the sediment budget of the river watershed can be developed. The objective of this study is to first identify the main sediment sources inside ravines to help constrain the contribution of different sources. The second objective is to estimate rates of sediment production inside ravine, in an effort to quantify the contribution of ravine sediment load to the Le Sueur River. The third objective is to calculate the rate of ravine growth in terms of its rate of change in width and depth.

\section{Thesis Outline}

Sediment production and dynamics in the Le Sueur River and in the ravines in particular is the focus of this research and is explained in more detail in sections I.I. - I.II. A review

of the literature is presented in Chapter II, where a highlight of the work done on gully erosion research by other scholars is summarized. These include a summary of gully erosion measurement techniques that had evolved over time and the current state of gully erosion modeling. 
Chapter III outlines the research methodology used to achieve the objectives of this research. Data sources and field collection are described in this chapter. This chapter also presents further detail on the development of the numerical model, its theoretical basis, parameter assumptions and simplifications. It gives the highlights on the high rate gully erosion equations following the approach of Torri and Borselli (2003) and the USLE which were incorporated into a simple research model to estimate the ravine sediment budget.

Results of this research are presented in Chapter IV. A parameter sensitivity analysis conducted to test the robustness of the model and assess the key model parameters is also presented in this chapter. The chapter also discusses the results and the model output in comparison to results from literature of similar study. The strengths and limitations of the chosen approach are discussed. Finally, conclusions drawn from this study and recommendations given for further research are presented in Chapters V and VI, respectively. 


\section{CHAPTER II. LITERATURE REVIEW}

Ravine erosion is an important soil erosion process on the lower Le Sueur River valley. Although its sediment contribution is significant, scarce quantitative research on the area has been done so far. There does not exist much literature on ravine erosion but research on gully erosion on the other has had recently gained attention. Permanent gullies are often defined for agricultural land in terms of channels too deep to easily ameliorate with ordinary farm tillage equipment, typically ranging from 0.5 to as much as $25-30 \mathrm{~m}$ depth (Soil Science Society of America 2001). Ravines in the lower Le Sueur valley are similar to permanent gullies but with deeper and wider valley, connecting relatively large area in the landscape. Previous studies of gully erosion have been reviewed in the following sections.

\section{$\underline{\text { Gully Erosion }}$}

Gully development and the rate of erosion in gullies is a well documented topic in erosion research. Most previous studies dealing with soil erosion by water had concentrated on rill and interill erosion. Recent studies however have given attention to gully erosion and consider gullies as another possible substantial source of sediments. According to the review by Poesen et al. (2003) and the data collected in 56 different catchments located in different parts of the world, soil loss by gully erosion accounted from $10 \%$ to $94 \%$ of total sediment yield caused by water. Moreover, in a review of the fingerprinting method of identifying the origin of sediments within catchments to determine the relative contribution of potential sources, the contribution of gully erosion accounted $80 \%$ in Australia, 90\% - 98\% in New South Wales, 60\% - 70\% in Chinese Loess Plateau, and 70\% in an Ethiopian highland (Valentin et al. 2005). 
In addition to being a substantial sediment source, gullies also aggravate water erosion by increasing the connectivity in the landscape hence promoting redistribution of sediment within the catchment and effective delivery of sediment from uplands to low lands and water courses (Poesen et al. 2003). The eroded sediment volume also increases with the density of active gullies within a catchment. For example, to study the impact of the presence of concentrated active gullies on the specific sediment yield of a catchment, Poesen et al. (2003) used reservoir sedimentation data of 22 selected Spanish catchments and survey of gullies within a $5-\mathrm{km}$ radius of the reservoir or river channels draining to the reservoir. The study found that for catchments with no gullies, the mean specific yield was 0.74 ton $\mathrm{ha}^{-1}$ year ${ }^{-1}$, for those with numerous gullies it was 9.61 ton $\mathrm{ha}^{-1}$ year $^{-1}$ and catchments with some gullies had mean specific yield of 2.97 ton $\mathrm{ha}^{-1}$ year $^{-1}$.

\section{Gully Types}

The two main types of gullies are Ephemeral gully and Permanent or classical gullies. The Soil Science Society of America (2001) explains that the main difference between those two types of gullies is the ease to fill the channel by normal tillage. Ephemeral gullies are small channels eroded by concentrated overland flow that can be easily filled by normal tillage only to reform again in the same location by additional runoff events (Soil Science Society of America 2001). Permanent gullies on the other hand are permanent features in the landscape, and are often defined for agricultural land in terms of channels too deep to easily ameliorate with ordinary farm tillage equipment. Poesen et al. (2003) summarizes some criteria used to distinguish the rills from gullies, such as "the 
square foot criterion" Poesen (1993): a gully has a minimum cross-sectional area of 929 $\mathrm{cm}^{2}$; Brice (1966): a minimum gully depth and width criteria of 0.3 and 0.6 meters; and Imeson and Kwaad (1980): a minimum gully depth criterion of 0.5 meters. However, there is no specific clear-cut definition to the upper limit of gullies.

\section{Gully Development}

Gully development is a threshold phenomenon which is controlled by temporal changes in flow hydraulics, rainfall, soil type, land use, topography, climate and weather (Poesen et al. 2003; Valentin et al. 2005). Sidorchuck (1999) explains that the main causes of gully initiation in a landscape are anthropogenic factors: changes in land use such as clearing of native forests, tilling of fallow lands and associated change of hydrological conditions in their rainfall- runoff system. According to Sidorchuk (1999), gully development has two stages. The initial stage where the gully development rate is very rapid and the last stage is where the gully size is near stable and reaches its maximum value. In the initial stage, gully morphological characteristics are not stable, the hydraulic erosion is predominant and rapid mass movement occurs on the gully sides and gully bottom. In a second stage, the rate of gully development decreases, and the gully is assumed to be in its final morphological equilibrium. At this stage, sediment transport and sedimentation are the main erosion processes in the gully, its width increases due to lateral erosion and slow mass movement transforms the gully sides. The last stage occupies the largest part of a gully's life time where as the initial stage accounts only $5 \%$ of gully's life time. Major morphological characteristics of the gully however are formed during the initial stage (Sidorchuk 1999). 


\section{Controlling Factors}

The magnitude of gully erosion varies according to its spatial scale and temporal scale (Poesen et al. 2003). Soil loss from gullies highly depends on the size of the study area considered. For study areas ranging between 1-10 ha or more gully erosion becomes important and its contribution to sediment yield might be more than that of rill and interill erosion. Furthermore, environmental factors such as topography, soil type, land use, gully type, climate and weather also control gully erosion. The magnitude of gully erosion in a study area fluctuates depending on the time scale of the study period. The variation may be attributed to the changes in land use and other environmental factors during the study period (Poesen et al. 2003).

\section{Techniques of Measuring Gully Erosion}

Several attempts have been used in the past to estimate and monitor gully erosion. In early studies such as those in New South Wales, Australia, gully erosion rates measurements involved the use of erosion pins and ground surveys, where the study area would be surveyed in defined intervals of time (Crouch 1990). However, this method was found to be time consuming and difficult to apply to the study of large areas with high gully density over a long period of time. In more recent studies, of short-term monitoring of gully head cut or gully wall retreat, (Vandekerckhove et al. 2001a; 2001b) regularly measured the distance between the edge of the gully head or wall and benchmark pins. In an effort to study long-term growth of valley-bottom gully Thomas et al. (2004) used annual surveys of the gully perimeter over 30 years and produced a three-dimensional surface for each topographic survey to estimate the increase in gully volume. 
Photogrammetric techniques were also used in other gully erosion researches. In the studies by Betts and DeRose (1999) and Martinez-Casanovas (2003) for example, DEMs were constructed from sequential aerial photographs for measuring and monitoring the volume of sediment lost by gully erosion in a geomorphologically unstable environment. For medium - term scale, an analysis of high-altitude aerial photographs in combination with ground measurements was also used to quantify volumetric gully head retreat rates for permanent gullies in Spain (Vandekerckhove et al. 2003).

Martinez-Casanovas et al. (1998) also applied Geographic Information System (GIS) techniques to analyze DEM of $25-\mathrm{m}$ resolution derived from multi-date aerial photographs to assess erosion rates in the gully system of NE Spain. The gully system in this study is characterized by vertical sidewalls, and is $11-60 \mathrm{~m}$ deep and $75-350 \mathrm{~m}$ wide. The study quantified that linear retreat rate of gully walls and maximum rate of channel incision was in the order of meters per year, while the average sediment production rate was in the order of tones ha ${ }^{-1}$ year $^{-1}$.

In studies carried out in small catchments in Qiaogou, China, Wu and Cheng (2005) used a high accuracy Global Positioning System (GPS) to measure the morphological parameters of gullies to investigate the short-term erosion rates of hill slope gullies, slope-area relationships, and thresholds of hill slope gully initiation. 
A method based on dendrochronology was also developed as an alternative to the traditional methods mentioned above. This method makes use of trees or parts of a tree affected by gully erosion revealing information on the history of the erosion process by datable deviations of their normal growth pattern (Vandekerckhove et al. 2001a). However, the authors report that methodological problems limit the application of the dendrochronological estimation of gully erosion.

\section{$\underline{\text { Gully Erosion and Sediment Transport Models }}$}

The historical development of research in gully erosion modeling is reviewed by Bull and Kirkby (1997). In this review, an attempt has been made to trace the development of gully erosion models, from the first stochastic models in the 1970 s to the more recent approaches of process-based representations of the system for understanding the theory behind gully initiation in the 1980s (Bull and Kirkby 1997; Kirkby and Bull 2000; Merritt et al. 2003). Another overview regarding a number of existing erosion and sediment transport catchment-scale models deserving specific mention include the review by Merritt et al. (2003). The literature comprehensively reviews a range of models that have been used to simulate aspects of erosion, sediment generation and sediment transport through a landscape at a catchment scale. The models reviewed range significantly in the erosion process they represent, the manner in which these processes are described and the temporal and spatial scales of application for which they were developed (Merritt et al. 2003). Furthermore, the review points out that, if alternate erosion sources contribute significantly to the generation of sediment (e.g. permanent gullies), then such processes need to be represented explicitly in the selected model. However, most of the catchment- 
scale erosion models don't account for gully erosion as a process explicitly. Table 1 provides a summary of the reviewed catchment-scale erosion models and the processes they explicitly represent. In this summary, it can be noted that only four out of the seventeen reviewed models incorporate routines to account for gully erosion.

Table 1. Process represented in the models reviewed after Merritt et al. (2003)

\begin{tabular}{|c|c|c|c|c|c|c|c|c|c|c|}
\hline \multirow[t]{2}{*}{ Model } & \multirow[t]{2}{*}{$\begin{array}{l}\text { Rainfall- } \\
\text { runoff }\end{array}$} & \multicolumn{3}{|c|}{ Land surface sediment } & \multirow[t]{2}{*}{ Gully } & \multicolumn{3}{|c|}{ In-stream sediment } & \multicolumn{2}{|c|}{$\begin{array}{l}\text { Sediment associated water } \\
\text { quality }\end{array}$} \\
\hline & & $\mathrm{G}$ & $\mathrm{T}$ & $\mathrm{D}$ & & $\mathrm{G}$ & $\mathrm{T}$ & $\mathrm{D}$ & Land & In-stream \\
\hline AGNPS & yes & yes & no & $\mathrm{no}^{\mathrm{a}}$ & yes & yes & yes & yes & yes & yes \\
\hline ANSWERS & yes & yes & yes & yes & no & no & no & no & no & no \\
\hline CREAMS & yes & yes & yes & yes & yes & no & no & no & yes & no \\
\hline EMSS & yes & no ${ }^{\mathrm{b}}$ & no & no & no & yes & yes & yes & no & no \\
\hline GUEST & yes & yes & yes & yes & no & no & no & no & no & no \\
\hline HSPF & yes & yes & yes & yes & yes & yes & yes & yes & yes & yes \\
\hline IHACRES-WQ & yes & no & no & no & no & yes & yes & yes & yes & yes \\
\hline $\mathrm{IQQM}$ & yes & no & no & no & no & no & no & no & no & no \\
\hline LASCAM & yes & yes & no & no & no & yes & yes & yes & yes & yes \\
\hline LISEM & yes & yes & no & no & no & yes & yes & yes & no & no \\
\hline MIKE-11 & yes & yes & yes & yes & no & yes & yes & yes & yes & yes \\
\hline PERFECT & yes & yes & no & no & no & no & no & no & yes & no \\
\hline SEDNET & yes & yes & no & no $0^{\mathrm{a}}$ & yes & yes & yes & yes & yes & yes \\
\hline SWRRB & yes & no & no & no & no & yes & yes & yes & yes & yes \\
\hline TOPOG & yes & yes & yes & yes & no & no & no & no & no & no \\
\hline USLE & no & yes & no & no & no & no & no & no & no & no \\
\hline WEPP & yes & yes & yes & yes & no & yes & yes & yes & no & no \\
\hline
\end{tabular}

G, sediment generation; $T$, sediment transport; $D$, deposition.

"Requires a sediment delivery ratio (SDR) to compute sediment yield from gross erosion.

${ }^{b}$ Uses prescribed loads for a land use type.

Based on this review, four models: the AGricultural Non-Point Source Pollution model (AGNPS), the Chemicals, Runoff and Erosion from Agricultural Management Systems (CREAMS), the Hydrological Simulation Program - FORTRAN (HSPF), and the Sediment River Network model (SEDNET) were examined to assess if the gully erosion routine explicitly represents the gully sediment generation, sediment transport in gullies, gully growth rates and the sediment loading at the gully outlet. Although these four 
models are capable of estimating gully sediment yield, sediment generation and transport in the gully, the capabilities to simulate gully growth rates and change in gully dimensions over time are not included in these models. SEDNET in particular, was developed as a tool to help identify the major sources of sediment to a stream network, location of sediment entrainment and the dominant erosion process contributing sediment to the network at the catchment scale. However, its applicability to this particular study is substantially limited by the extensive data requirements, namely a grid of mean annual rainfall, soil erodibility, a grid of gully density and a description of the mean characteristics for each link (Merritt et al. 2003).

Woodward (1999) describes the Ephemeral Gully erosion Model (EGEM) which is a modification of the Agricultural Research Service Ephemeral Gully Erosion Estimate (EGEE) to meet the Natural Resources Conservation Service (NRCS) needs. The EGEM has two major components: the hydrology component which uses the NRCS curve number, drainage area, watershed flow length, average watershed slope, and 24-hr rainfall and standard NRCS temporal rainfall distributions to estimate peak discharge rates and runoff volumes. The erosion component is a combination of empirical relationships and physical process equations to compute the width and depth of the ephemeral gully. However, this model was built on the assumption that ephemeral gullies typically erode to the tillage depth, limited to 18 inch or less and further work is needed to involve the capability to simulate erosion in branching gully systems which limits its application to large permanent gullies such as the ravines in the lower Le Sueur River. 
Sidorchuck (1999) attempted to model gully erosion based on a thorough description of the physics involved in the process. He introduced the concept that the gully undergoes through two stages as it changes its morphology. The two stages are then modeled in two types of gully erosion models: the dynamic models which predict the rapid changes of gully morphology at the initial stage of gully development, and the static models which calculate the final morphometric parameters of stable gullies. In the initial stage, the morphological characteristics of the gully are far from stable. In the second stage however, when averaged for several years, the depth and width of the gully don't change significantly (Sidorchuk 1999); sediment transport and sedimentation are the main processes at the gully bottom and its width increases due to lateral erosion. The dynamic gully erosion model is based on the solutions of mass conservation and deformation equations which characterize the factors that control rate of gully incision (water flow velocity, depth, turbulence, temperature, soil texture and mechanics, and vegetation cover). The static model represents the change in the longitudinal profile of the ravine. The sediment flux in the gully is defined by the equation of mass conservation and the change in gully bottom according to the sediment budget is estimated by the equation of deformation. Both model stages are two dimensional (space-time); they attempt to represent the change in gully in time and distance. The models would well represent the sediment budget in the study ravines in the lower Le Sueur River, if sediment and water data of the ravines were measured along the ravine length in a set of time intervals. However, presently available data at the Le Sueur River has been measured at the ravine head and outlet only; hence the applicability of Sidorchuk's gully erosion model is limited at present. 
Another approach to modeling gully erosion is the high rate gully erosion equations described in the study by Torri and Borselli (2003). This study presents an approach to gully erosion based on a mass balance equation derived for a dynamically developing gully system. This model formulation attempts to estimate the sediment budget of a gully using sediment generation rates of the gully wall, gully bed and sediment being deposited in the gully. The derived equations link gully widening rate to gully deepening rate during peak discharge. The model assumes a one - dimensional flow along the centerline of the stream channel. It also assumes a prismatic channel and doesn't take into account the cross-stream variations due to variable channel cross-section features. However, the model has the advantage of compatibility with currently available data in the Le Sueur River gullies, and can provide useful insight into the relative contribution of different components of the sediment budget in gullies with limited measured data. Following the approach of Torri and Borselli (2003), a simple numerical simulation model was developed in this thesis for the study area and is described further in the model development section in Chapter III. 
CHAPTER III. RESEARCH METHODOLOGY

$\underline{\text { Study Area Description }}$

\section{Le Sueur River Watershed Characteristics}

The Le Sueur River is located in the south-central part of Minnesota. Its watershed is one of the twelve major watersheds of the Minnesota River Basin with a total area of approximately 2880 square kilometers. The Le Sueur River flows northward to its confluence with the Blue Earth River. About 5 kilometers north, the Blue Earth River then joins the Minnesota River at the city of Mankato, $\mathrm{MN}$ and flows northward to its confluence with the Mississippi River at the Twin Cities- Minneapolis/St. Paul. The drainage network of the Le Sueur River watershed is defined by the main channel of the river and its major tributaries: the Mapple River and the Big Cobb River and smaller streams. There also exists an extensive network of artificial drainage - ditches and tile drainage installed to aid water infiltration in the agricultural fields. According to the MPCA, the Le Sueur River is the primary contributor of suspended sediments to the Minnesota river (24-30\%) (Minnesota Pollution Control Agency et al. 2007).

A major part of the Le Sueur River watershed area has low-gradient to flat uplands. The study of Gran et al. (2008) shows that the lower reaches of the river and its major tributaries are currently incising, and the knick points are migrating upstream causing a high relief to the incised portion of the watershed. High bluffs border many of the outer bends along the main stem of the Le Sueur River. Deeply incised ravines are also prevalent especially towards the lower reaches of the river. 
Agriculture is the dominant land use within the watershed of the Le Sueur River (87\%) (Minnesota Pollution Control Agency et al. 2007). Corn and soy bean are the common crops. However, the poorly drained soils in the agricultural fields would make it impossible to grow crops without a better drainage mechanism. Farmers commonly use subsurface drainage tiles to minimize runoff and increase infiltration in the agricultural fields. Installation of the subsurface drainage network and surface ditches in the landscape has completely altered the hydrology of the watershed. It rapidly increased the vertical hydraulic conductivity of the agricultural fields to create optimum soil moisture for a particular crop type. It also increased the horizontal hydraulic conductivity so that water flows easily and more rapidly to ditches, ravines or the river.

Although the artificial drainage network has allowed enhanced crop production in the area, approximately $89 \%$ of the wetlands were lost through drainage. The rapid movement of water through the watershed also increased the pollutant and sediment transport and loading to the water channels. Concentrated flow from several drainage tiles is directed into the ravines. The concentrated flow from the tiles may not carry significant sediment load to the ravines when compared to surface runoff, but it possibly affects the sediment dynamics and production inside the ravine.

\section{Ravine Characteristics}

Ravines in the lower Le Sueur valley act as runoff and sediment pathways linking the uplands (agricultural fields) and the river valley bottom. The lower reaches of the Le Sueur River are currently incising, leading to migration of the knick point upstream, 
(Gran et al. 2008). In response to knick point migration, most of the ravines in the lower Le Sueur are changing their morphological characteristics (length, depth, width, area, and volume) and are periodically flushing significant sediments. Hence, through and below the major knick zones, ravines are believed to be not only a link but also an important sediment source.

Observations from field research conducted during the summer of 2008 show that most of the bluffs along the main stem of two gauged ravines are actively eroding. Also, mass wasting of the steep ravine valley walls and rapid incision of the fluvial channels within the ravine are producing sediment. Several large fill terraces are present along the main stem, towards the mouth of the ravines. Recent incision through these extensive fill terraces may be another sediment producing source. Sediment storage in the ravines also occurs, behind woody debris jams as well as in locations where local base level has been raised by the insertion of a culvert.

\section{$\underline{\text { Data Collection }}$}

To achieve the objectives of this study, a first task of this research consisted of field data collection. The collected data was mapped using GIS layers for further analysis. Following this, a numerical model to study the sediment transport was developed. These activities are described in more detail in the sections below. 


\section{Field Topographic Observations}

The main objective of the field work in summer 2008 was to observe erosion activities inside the two study ravines along the lower reaches of the Le Sueur, and collect data to help establish a more accurate estimate of the ravine sediment production. Two ravines were selected as study sites because of the availability of installed field instrumentation. The study sites are located about 6 kilometers south of the city of Mankato, MN and 2 miles west of State Route-22 (SR-22). The headcut of one of the study ravines is located south of the County Route-90 (195 ${ }^{\text {th }}$ ST, CR-90) and continues southward parallel to SR22 to join the Le Sueur River. The second ravine starts few meters west of County Route8 (Monks Ave, CR-8) continues southwards and joins the Le Sueur River. In this report the ravine on CR-90 is denoted as CR-90 and the second ravine as CR-8. The location of the study sites is depicted in Figure 4. 


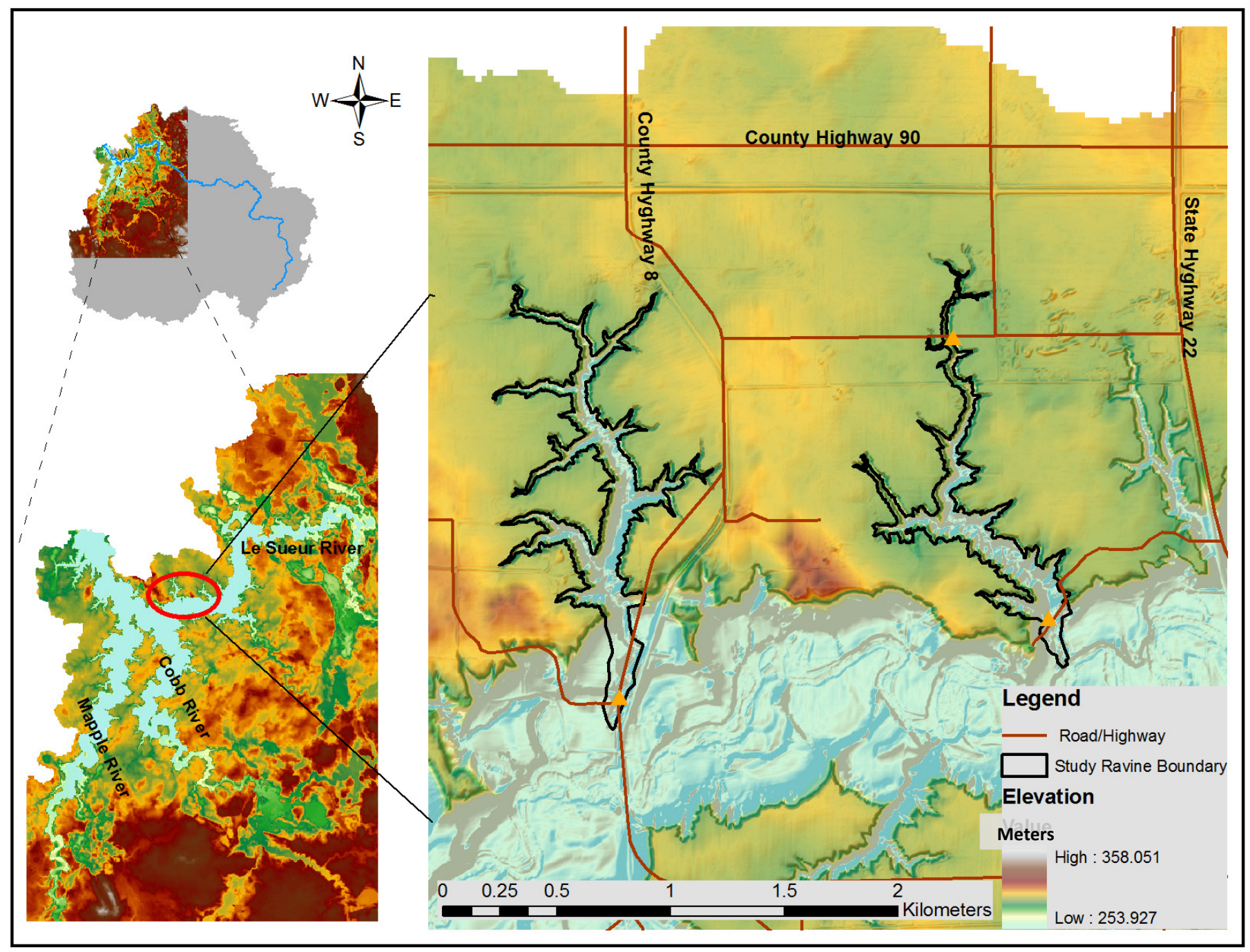

Figure 4. Geographic Location of Study Ravines in the Lower Le Sueur Watershed 
In 2007, the field research team at the National Center for Earth-Surface Dynamics (NCED), St. Anthony Falls Lab at the University of Minnesota, had started to monitor the water discharge and water quality of the two ravines. Two ISCO auto samplers were installed at the outlet of the two ravines and one at a culvert a few meters downstream of the headcut of the ravine on CR-90. The ISCO auto samplers recorded the water-level every 15 minutes and took water samples during storm events. The Water Resource Center of Minnesota State University monitors both gages. Water quality data for storm events between the months of April and August 2008 was obtained from this office. A comparison of the suspended sediment concentration measurements taken during these storm events showed that a significant amount of sediment is being flushed out of these ravines. For the ravine on CR-90 for example, Figure 5 shows a plot of the Total Suspended Solids (TSS) measurements taken during the 30 storm events show that TSS concentrations at the mouth of the ravine are one of magnitude higher than the TSS measurements taken near the ravine head. 


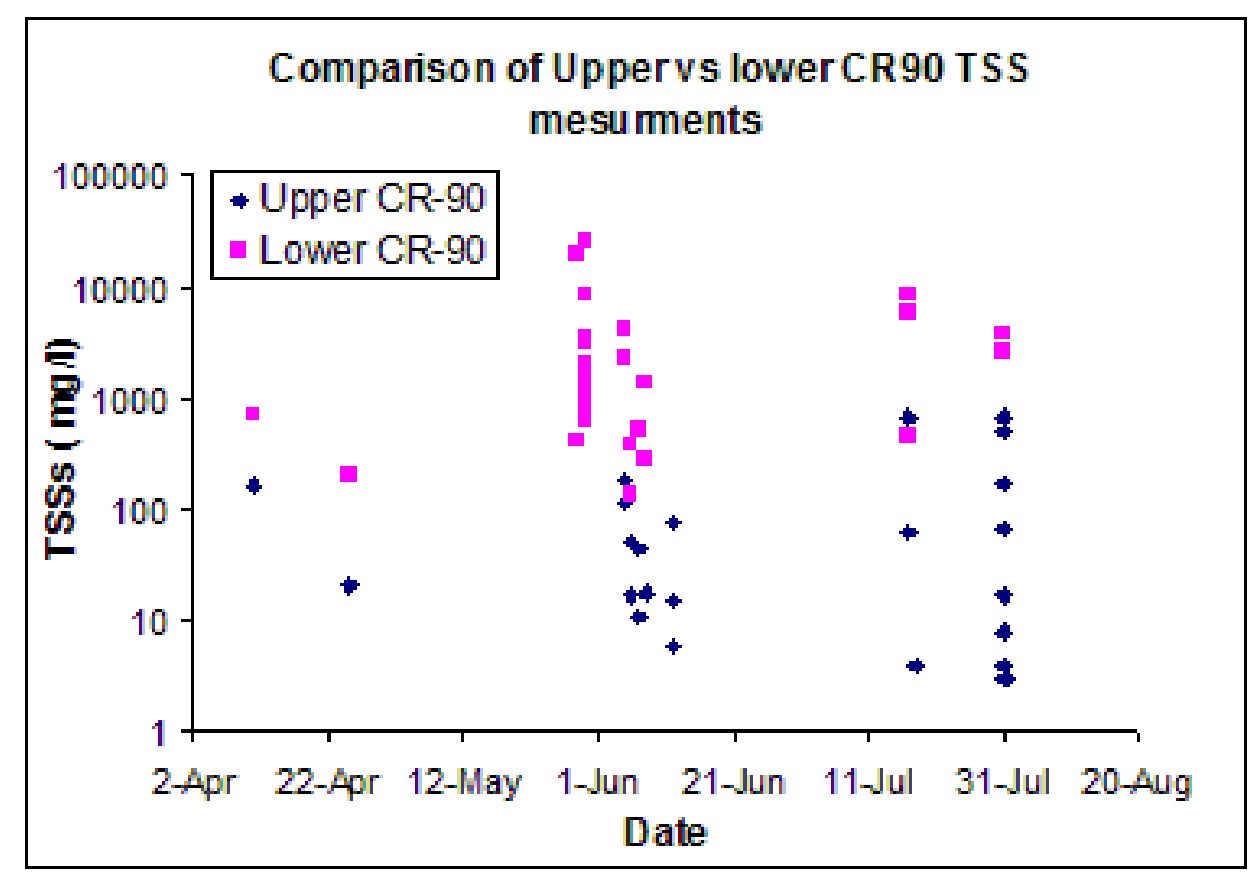

Figure 5. Comparison of TSS measurements in 2008 of the upper and lower gauges on CR-90.

\section{Bluffs and Terraces}

The second task of the field research hence was to locate the major sources of sediment inside the ravines. Inside the study ravines, most of the bluffs along the main stem are actively eroding (Figure 6). Land sliding of the steep ravine valley walls and rapid incision of the fluvial channels within the ravine are also observed. There are several large fill terraces along the main stem, especially towards the mouth of the ravines. Recent incision through these extensive fill terraces may be another sediment producing source (Figure 7). 


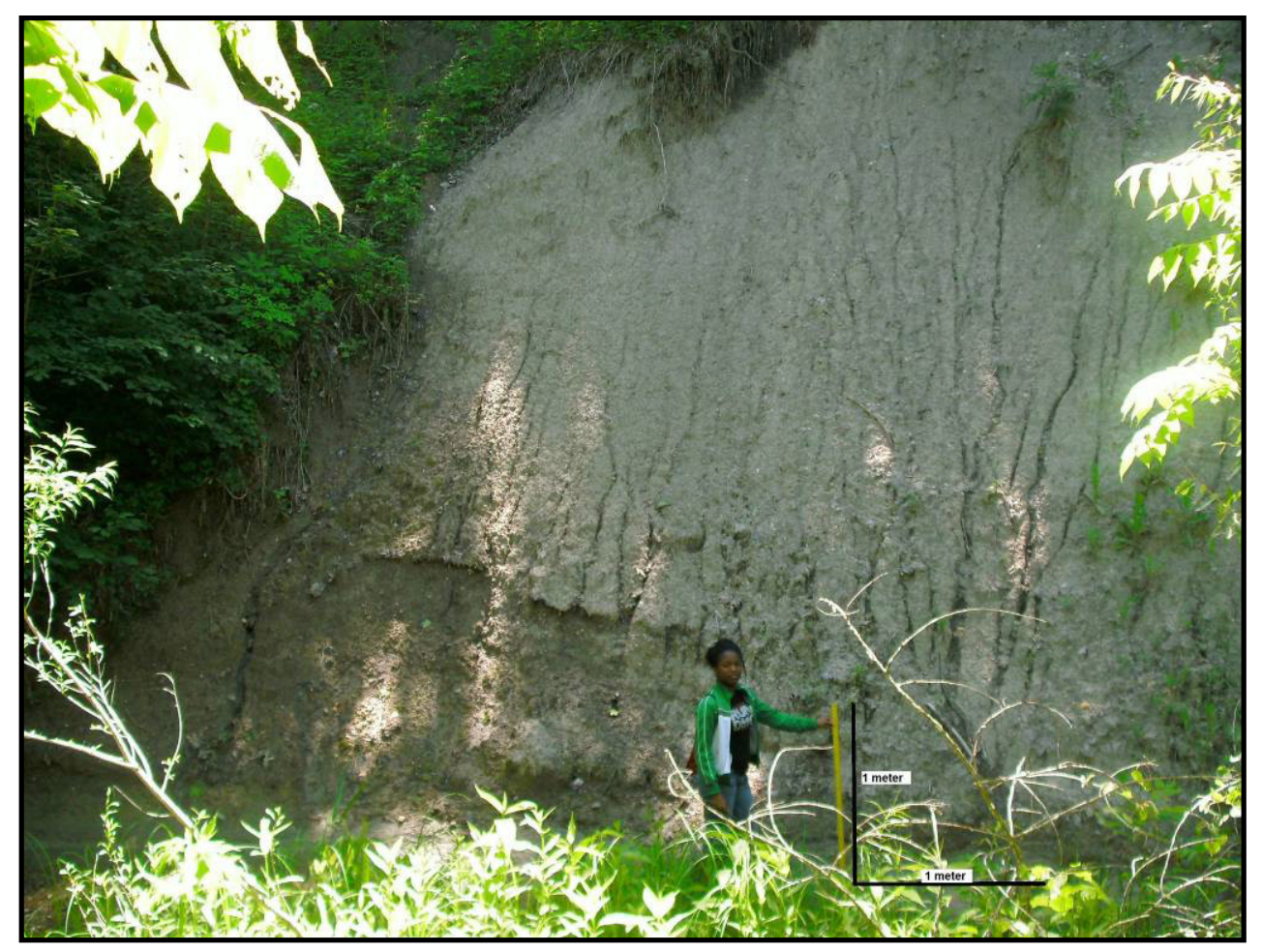

Figure 6. Bluff along the main stem of ravine CR-90. (about 6 meter high)

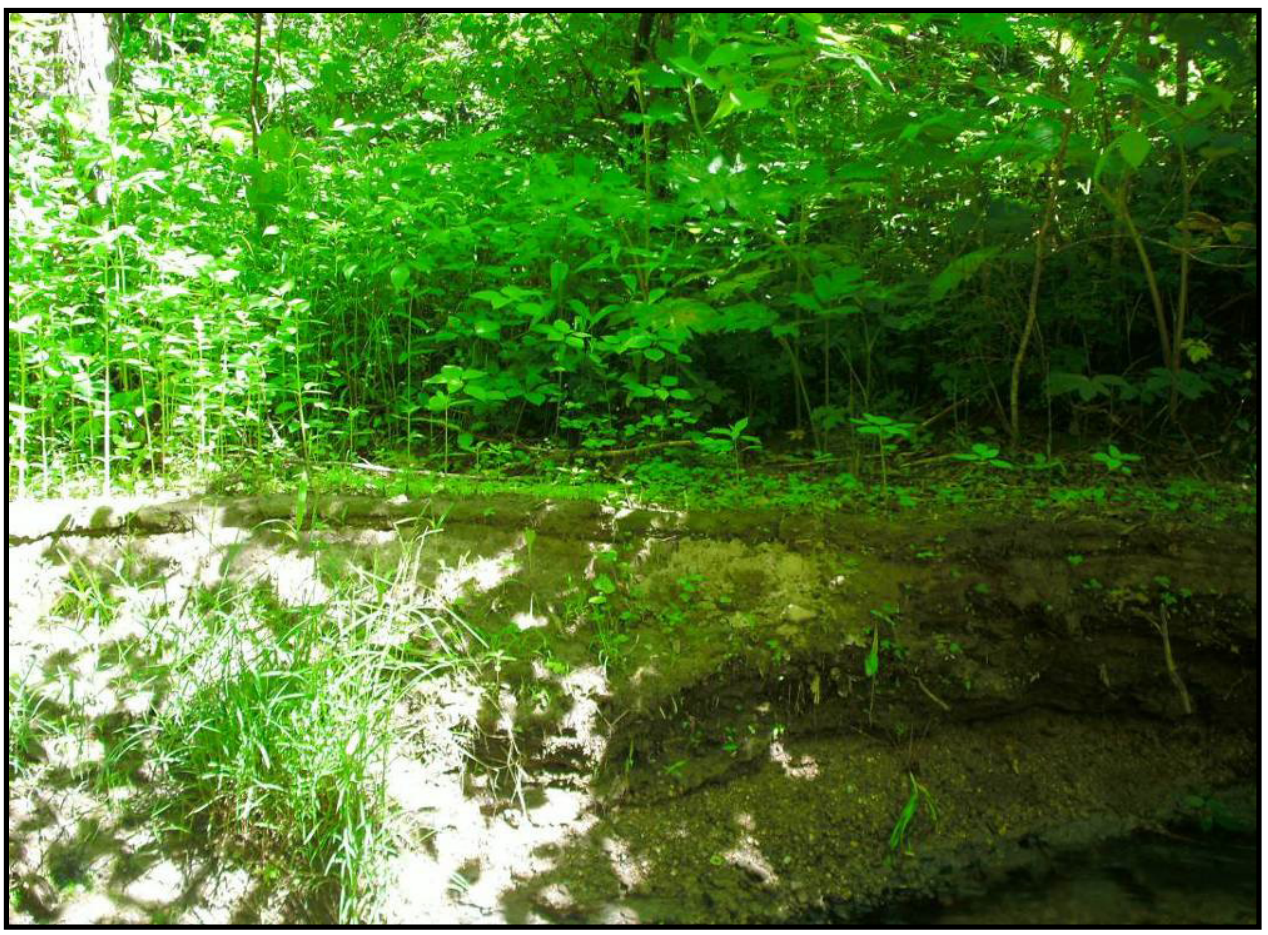

Figure 7. Old Terrace along the main stem of CR-90 
To help map the major sources of sediment inside the ravines, a GPS was used to record the longitude and latitude location of bluffs and terraces. Soil samples from some of major bluffs and major terraces were also collected to determine the grain size distribution. A comparative estimate of the geometry such as the surface area and slope of major bluffs, surface area and depth of major terraces were also recorded. There are also bluffs located inside tributaries of the ravines. The end of the tributary where it meets the main stream can be as small and narrow as 30 centimeters and lead to a 12 meter high bluff at the head. The water sources for the tributaries are either from tile drains or concentrated overland flow. The velocity and water depth of the stream in the ravines varies. At some locations, the water depth was very shallow but at others it reached up to knee high.

Along the main stem and tributaries of ravine CR-8, 17 major bluffs were located. The largest of all has a surface area about 190 square meters, with sandy deposits and some vegetation cover. Ravine CR-90 has relatively larger bluffs; the location and the geometry of 19 of these major bluffs were recorded. The largest bluff in this ravine has a height of 12 meters and surface area of 240 square meters. Most bluffs in both ravines have a very steep surface slope and are actively eroding. 


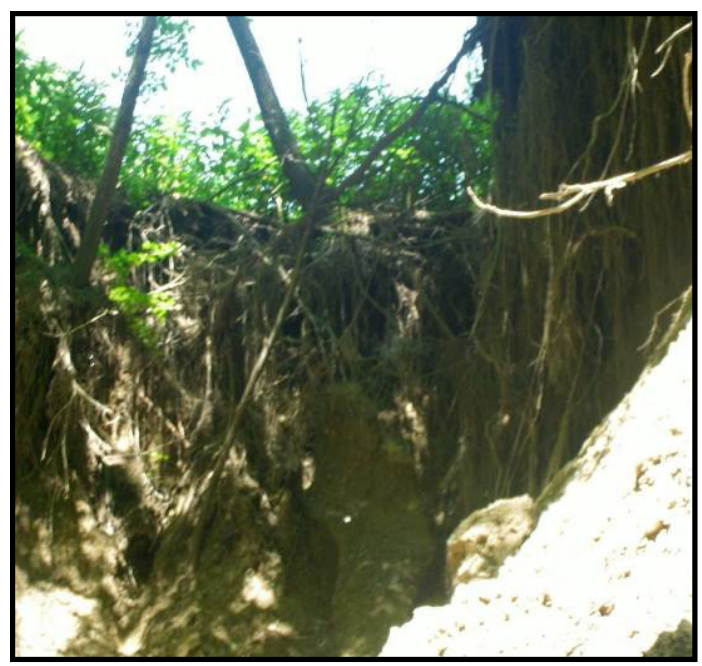

(A) Slumping top of ravine

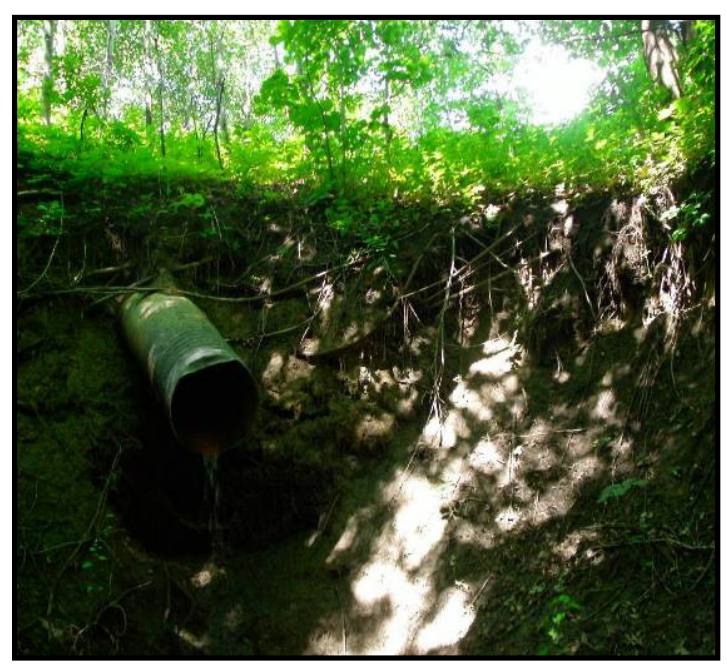

(B) A plunge pool at the base of the headcut.

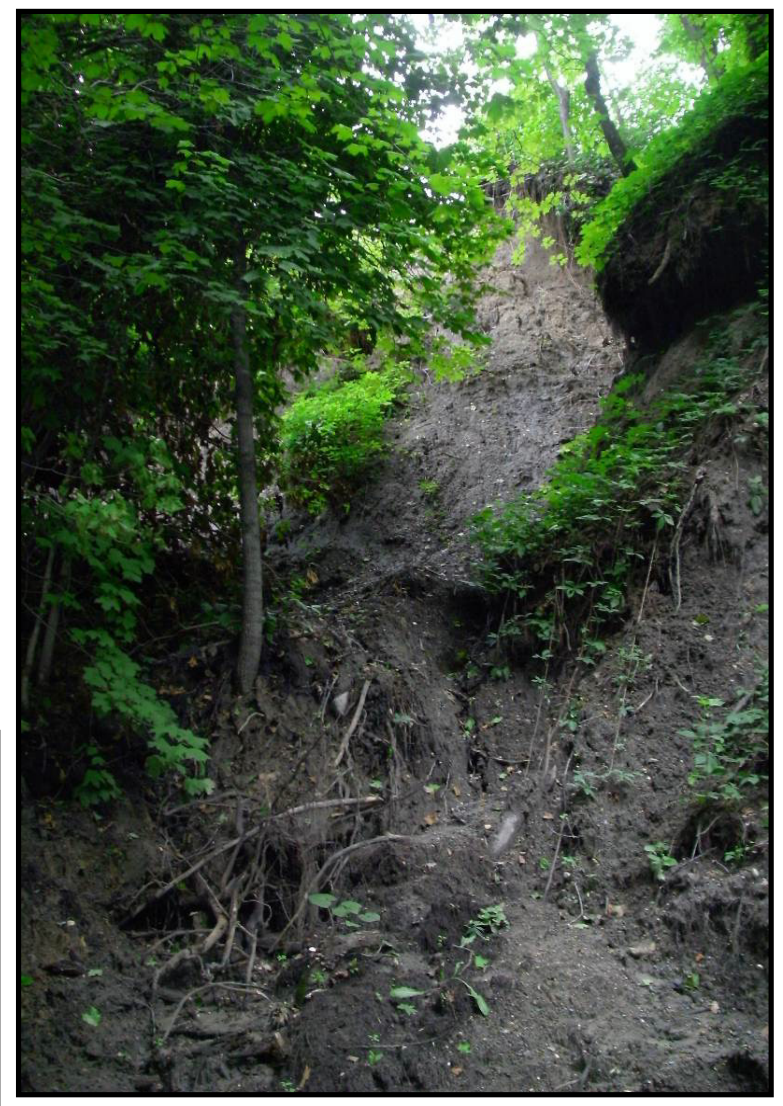

(C) Shallow Land slide of ravine wall.

Figure 8. Type of failure of the ravine walls and headcut.

The collected data such as the GPS coordinates for bluff and terrace locations, pictures, estimated bluff heights and widths, terrace height and top area, general stratigraphy and as well as other remarks were composed in a tabular format in spreadsheets. Using the coordinates and GIS, a map of major bluff and terrace locations along the two study ravines was produced. Figures 8 and 9 show maps of the major bluffs along with terraces, points of entry of overland flow, and tile drainage outlets on the periphery of CR-90. Figure 9 depicts typical potential sediment sources inside these systems. 


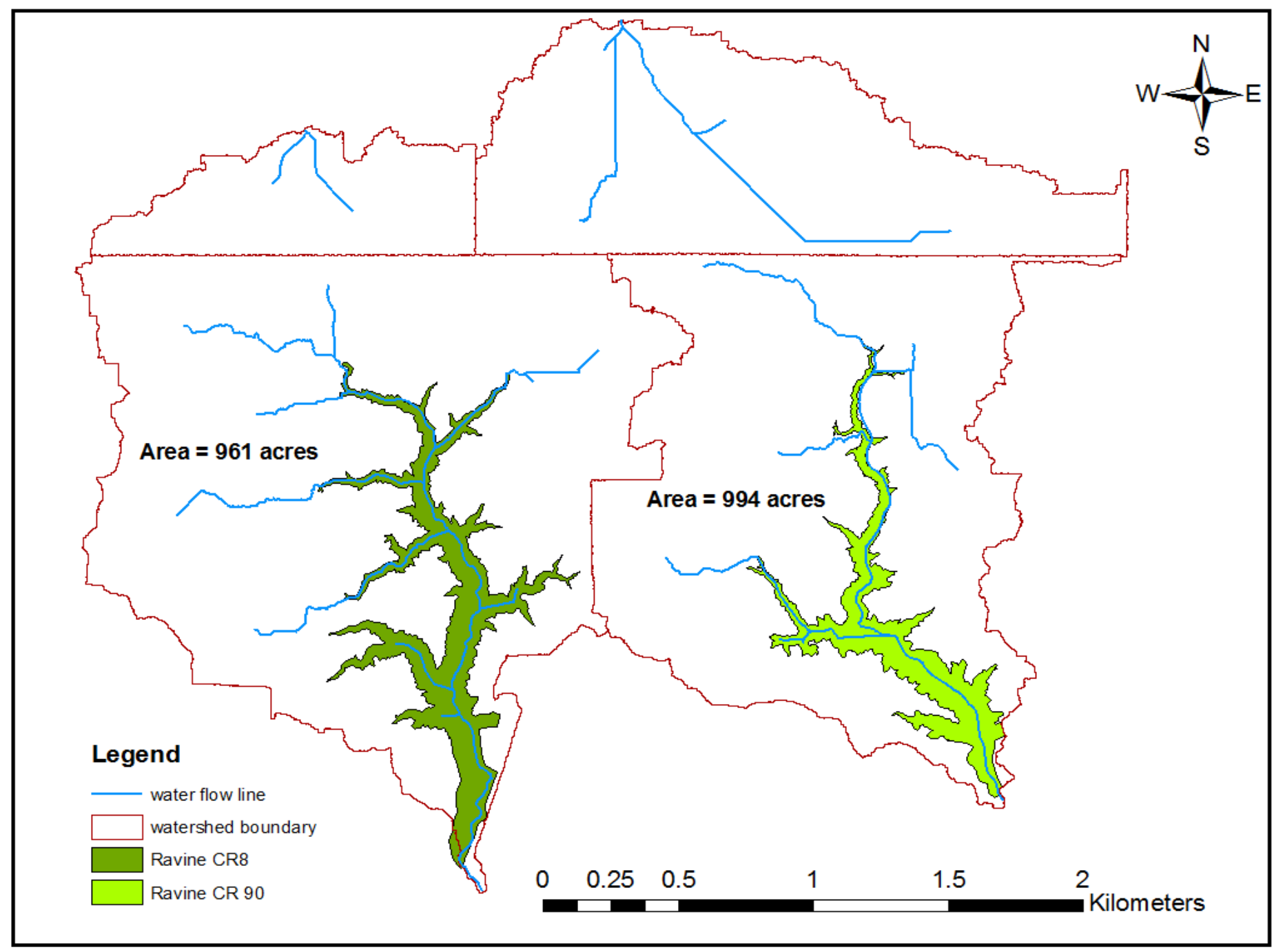

Figure 9. Map of study ravines and their watersheds. 


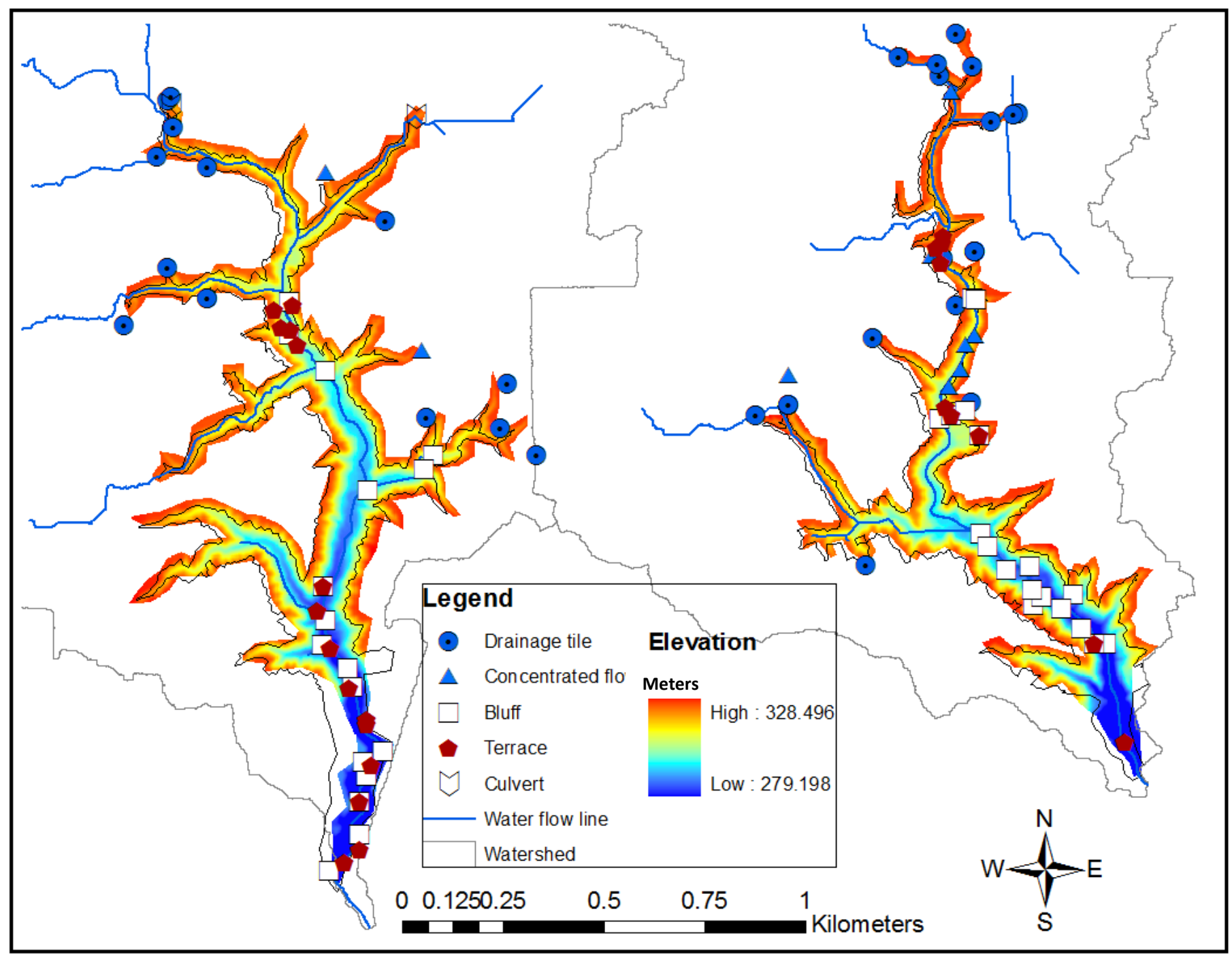

Figure 10. Map of bluffs, terraces, and entry points of concentrated flow. The concentrated flow comes from overland flow from the agricultural fields and the tile drainage into the ravine. 


\section{Drainage Tiles}

Observations of different tile drains include metal, concrete, and plastic with slits and collector drains. The collector drains have a diameter of 27 - 36 inches, as depicted in Figure 11. They have smaller tile drains connected to them and the plastic drains with slits are able to collect water from the sides as it seeps through the ground. Other tile drains range from as small as 5 inches to as big as 14 inches. Some tile drains caused deep valleys in the walls of the two ravines. This incision on the slopes might affect the sediment that is being contributed to the ravines. The ravine walls are being incised to about 1.5 meters at some locations. The incision destabilize the ravine walls and walls fail by slumping on the fluvial channel

The location of control structures such as culverts and bridges along the ravines was recorded in GPS. Detailed mapping of the study ravines along with the collected data is presented in Appendix A.

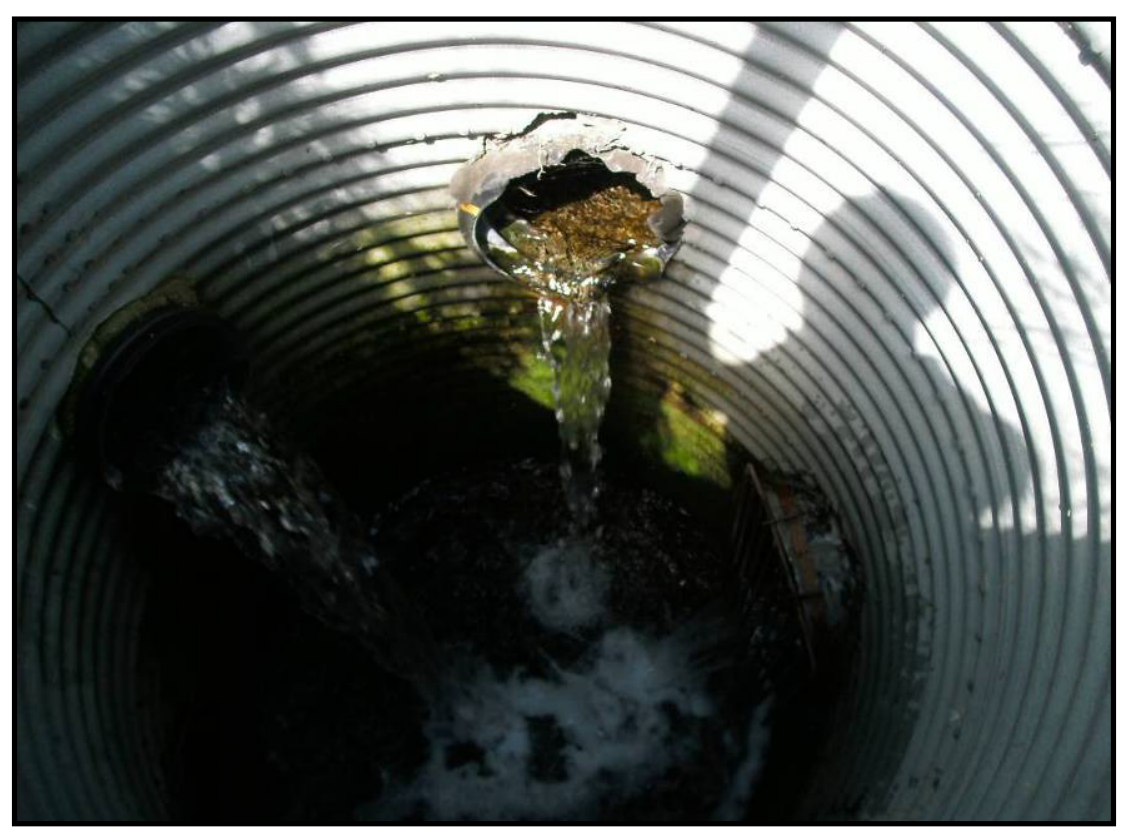


(A)Collector drain on the agricultural field 


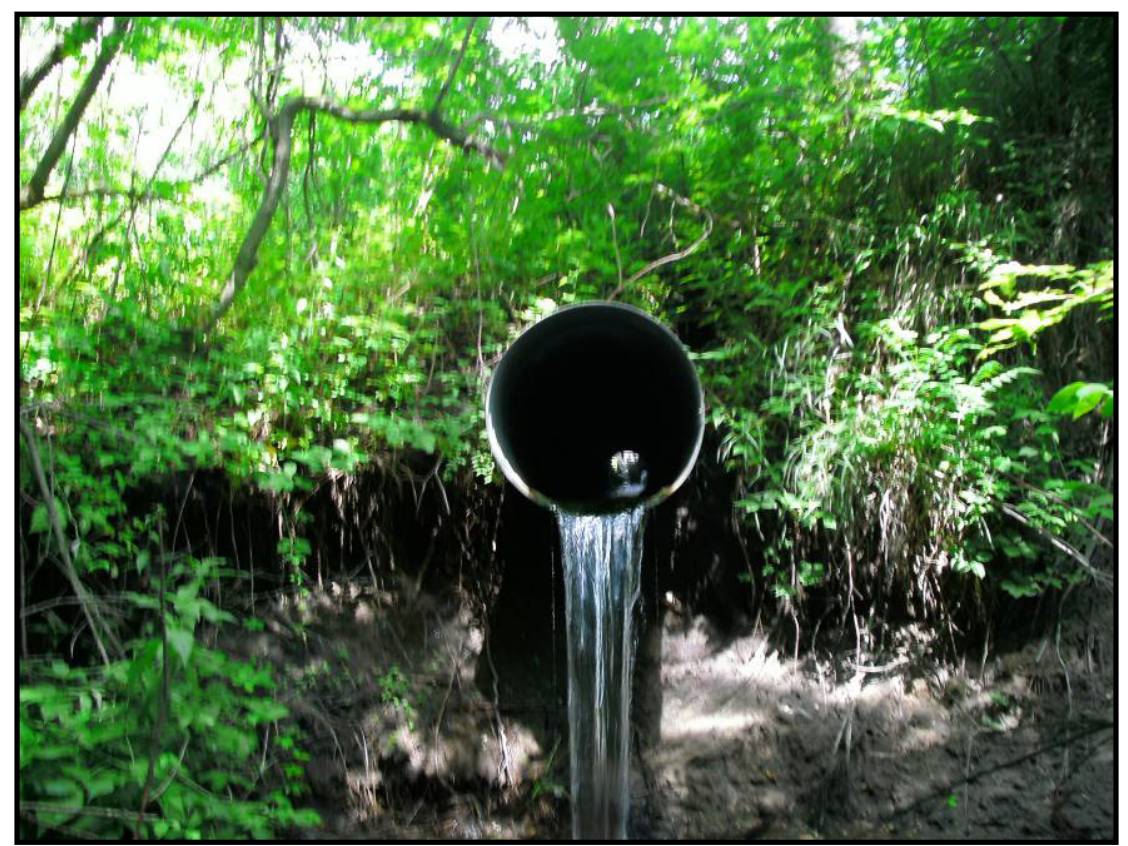

(B) A tile draining water from the collector drain in to a ravine

Figure 11. Drainage tiles at the head of a tributary of Ravine CR-90.

\section{Ravine Geometry Estimations}

An accurate estimate of the ravine geometry is the first step to calculating the sediment production and loading to the Le Sueur River. The aspects of morphology of these study ravines in the lower Le Sueur valley are similar to that of permanent gullies. According to the Soil Science Society of America (2001), permanent gullies are often defined for agricultural land in terms of channels too deep to easily ameliorate with ordinary farm tillage equipment, typically ranging from 0.5 to as much as $25-30 \mathrm{~m}$ depth. When compared to the geometry of gullies, the ravines in the study area have deeper and wider valley, steep banks, eroding bluffs, large terraces and vegetation cover of dense trees. These ravines also connect relatively large areas in the landscape. The total channel 
length of the ravine along the $\mathrm{CR}-90$, for example, is approximately 3700 meters, measuring from the headcut to its mouth along the ravine valley including the stream length of its major tributaries. This ravine drains an agricultural area of about 990 acres. The topography surrounding the study ravines has a very gentle slope of $0 \%-2 \%$. A DEM at 3 meter resolution of the Le Sueur River watershed was obtained from the Blue Earth County. Using GIS tools of spatial analyst and ArcHydro, topographic characteristics of the two ravines were derived from the LiDAR image. The area of the watershed, channel length, ravine surface area, and average slope were directly calculated in ArcGIS. The mean width of the ravines was calculated by dividing the ravine planimetric area by the channel length. Similarly, the mean depth was estimated by dividing the ravine volume by its planimetric area. Table 2 summarizes the results from the calculations performed in ArcGIS.

Table 2. Summary of Ravine morphometric parameters.

\begin{tabular}{lll} 
Description* & Ravine CR-90 & Ravine CR-8 \\
\hline Drainage area (acres) & 994 & 961 \\
Channel Length ( $m)$ & 3760 & 4900 \\
Ravine planimetric area (acres) & 56 & 80 \\
Volume (million cubic meters) & 9.26 & 5.79 \\
Mean gully top width (m) & 61 & 66 \\
Mean Gully Depth (m) & 41 & 18 \\
Mean gully bank slope (\%) & 133 & 55 \\
\hline
\end{tabular}


Average longitudinal slope (\%) 32

Average upland Slope (\%) $\quad 1.97$

Vegetation cover

ISCO auto sampler
Dense-tree

At the ravine head and outlet At the ravine outlet ${ }^{*}$

\footnotetext{
*Estimations are the results of calculations in GIS.
}

\section{$\underline{\text { Numerical Model Development }}$}

In an effort to quantify the sediment budget of deeply incised ravines in the lower Le Sueur River watershed (with its corresponding significance in the sediment budget of the Le Sueur watershed), gully-erosion equations developed by Torri and Borselli (2003) and the USLE model were arranged into a numerical model.

In this model formulation, the sediment budget of the ravines is quantified as the difference between the storage of sediment and the sum of sediments loads derived from the agricultural fields, ravine side walls, terraces and ravine bed. Once the gully-erosion equations were arranged, a 30 year survey and sediment data from gully growth-rate study in Iowa by Thomas et al. (2004) was used as a case study. To justify the validity of the assumptions and simplifications of the theoretical framework in this model, the model outputs were successfully compared to the data from the literature for this test case. Using the available sediment and water flow data for the two study ravines, the DEM of the area, along with reasonable assumptions of some parameters, the model was run to estimate the sediment budget in the study ravines of the Le Sueur River. The preliminary 
results for the sediment measured time period of April to October 2008 are presented in the following sections.

\section{Model Description}

\section{Theoretical Framework of the Model}

The rate of gully erosion and growth are controlled by flow parameters and soil texture. With the limited data available, this study aims to use as few parameters as possible, yet preserve the physical gully erosion process description. The equations developed by Torri and Borselli (2003) for high rate gully erosion use a few parameters, and hence were adopted in the numerical model presented in this thesis.

The main channel of the ravine/gully is assumed to be prismatic with a rectangular crosssection. Figure 12 shows the sketch of the gully cross-section, the sediment sources and storages. The channel has a length $L$, a depth $D$ and width $W$. The amount of sediment leaving the channel in a given time interval is $\Delta Q$ sto. 


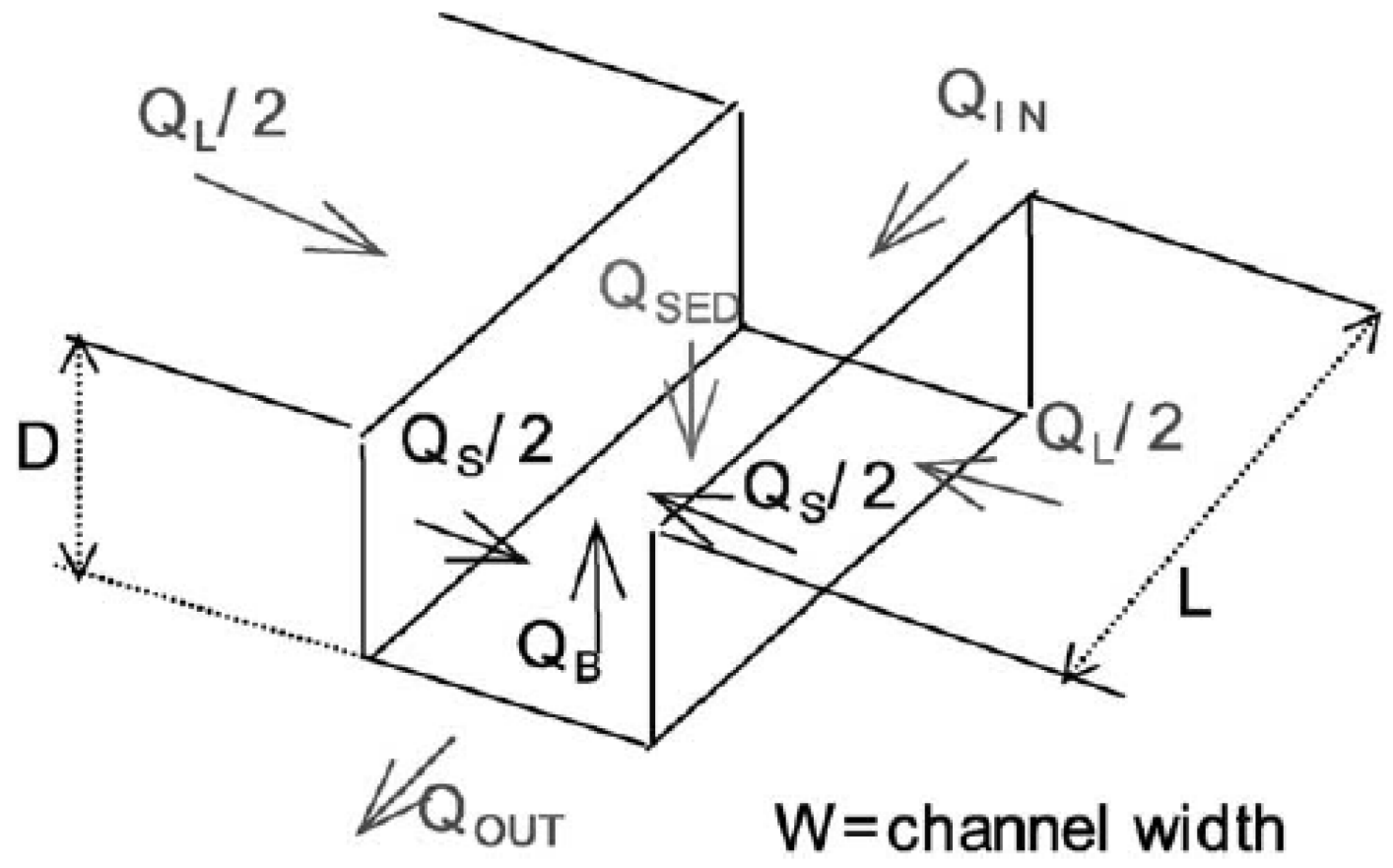

Figure 12. Sketch of gully cross-section with sediment sources.

(Torri and Borselli 2003)

The sediment budget is calculated as the difference between the sediment storage and sediment fluxes from the agricultural fields, ravine side walls and ravine bed. It is given by equation (1).

$$
\Delta Q_{S T O}=Q_{I N}-Q_{\text {Out }}+Q_{L}+Q_{S}+Q_{B}-Q_{S E D}
$$

where,

$$
\begin{aligned}
& Q_{I N} \quad=\text { Sediment from upstream entering the gully }\left(\mathrm{kg} \mathrm{day}^{-1}\right) \\
& Q_{\text {OUT }} \quad=\text { Sediment budget. Sediment leaving the gully }\left(\mathrm{kg} \mathrm{day}^{-1}\right) \\
& Q_{L} \quad=\text { Lateral Flux. Sediment from uplands entering the gully }\left(\mathrm{kg} \mathrm{day}^{-1}\right) \\
& Q_{S} \quad=\text { Sediment flux from gully banks }\left(\mathrm{kg} \mathrm{day}{ }^{-1}\right) \\
& Q_{B} \quad=\text { Upward flux. Sediment from gully bed }\left(\mathrm{kg} \mathrm{day}^{-1}\right)
\end{aligned}
$$




$$
\begin{aligned}
& Q_{S E D}=\text { Downward flux. Sediment settling in the gully }\left(\mathrm{kg} \mathrm{day}^{-1}\right) \\
& Q_{S T O} \quad=\text { Sediment storage in the flow }\left(\mathrm{kg} \mathrm{day}^{-1}\right)
\end{aligned}
$$

For a small time interval, the variation of sediment momentaneously suspended in water passing through a small segment of channel is then given as,

$$
\frac{\partial q_{S T O}}{\partial t}=q_{I N-O U T}+q_{L}+q_{S}+q_{B}-q_{S E D}
$$

The basic sediment rate equations for sediment loads from gully sides, gully bed and settling sediment are given by Torri and Borselli (2003) as follows:

$$
\begin{aligned}
& q_{S}=2 k_{S}(z)\left(e_{f} p-p_{c r}\right) D \\
& q_{B}=k_{B}(z)\left(p-p_{c r}\right) W \\
& q_{S E D}=\frac{q_{o, S T O}}{W} u_{S E D}+\rho D \frac{\partial W}{\partial t}
\end{aligned}
$$

where,

$$
\begin{array}{ll}
W & =\text { Mean Gully width }(\mathrm{m}) \\
\mathrm{D} & =\text { Mean Gully depth }(\mathrm{m}) \\
\rho & =\text { Soil bulk density }\left(\mathrm{kg} \mathrm{m}^{-3}\right) \\
k_{S} & =\text { Coefficient of soil erodibility of gully walls }\left(\mathrm{day}^{2} \mathrm{~meter}^{-2}\right) \\
k_{B} & =\text { Coefficient of soil erodibility of gully bed }\left(\mathrm{day}^{2} \mathrm{~meter}^{-2}\right) \\
u_{S E D} & =\text { Sedimentation velocity in a turbulent flow }\left(\mathrm{m} \mathrm{s}^{-1}\right) \\
p & =\text { Flow aggressiveness }\left(\mathrm{kg} \mathrm{day}^{-2}\right) \\
p_{c r} & =\text { Critical flow aggressiveness }\left(\mathrm{kg} \mathrm{day}^{-2}\right) \\
e_{f} & =\text { Efficiency coefficient }- \text { the ratio between the force exerted by flow on } \\
& \quad \text { gully banks and force exerted on the gully bed (dimensionless) } \\
q_{S} & =\text { Rate of sediment load from gully banks }\left(\mathrm{kg} \mathrm{day}^{-1}\right)
\end{array}
$$




$$
\begin{aligned}
q_{B}= & \text { Rate of upward flux. Sediment from gully bed }\left(\mathrm{kg} \mathrm{day}^{-1}\right) \\
q_{\text {SED }}= & \text { Rate of downward flux. Sediment settling in the gully }\left(\mathrm{kg} \mathrm{day}^{-1}\right) \\
q_{L}= & \text { Rate of lateral flux }\left(\mathrm{kg} \mathrm{day}^{-1}\right) \\
q_{\text {IN-Out }}= & \text { The difference between rate of sediment entering from upstream and } \\
& \text { leaving the gully }\left(\mathrm{kg} \mathrm{day}^{-1}\right) \\
q_{o, S T O}= & \text { sediment momentaneously suspended in water passing through a small } \\
& \text { segment of channel }\left(\mathrm{kg} \mathrm{day}^{-1}\right)
\end{aligned}
$$

Equations for the other remaining sediment rates of the sediment budget are not explicitly given on the referenced literature. However, the rate of sediment from upstream entering the gully and leaving the gully can be calculated using the measured total suspended sediment at the ravine head and mouth. The measured TSS in mass/volume was multiplied by the measured water discharge in volume/time to obtain suspended sediment discharge in mass/time. To estimate the lateral sediment flux coming from the uplands, the USLE and the RUSLE models were used. The estimates however were essentially equivalent, hence the USLE model was adopted.

\section{The Universal Soil Loss Equation - USLE}

The Universal Soil Loss Equation is a widely used regression model for predicting soil erosion. It is an empirical model used to predict soil loss due to sheet and rill erosion. The equation was developed from over 10,000 plot-years of runoff and soil-loss data, collected on experimental plots of agricultural land in 23 states by the U.S Department of Agriculture (Simons and Senturk 1992). Measurements of precipitation, runoff, and soil loss associate with 42 stations were continuously collected for a period of 5-30 years or 
more. Field plots of 72.6 feet long on a $9 \%$ uniform slope in bare fallow soil and tilled were arbitrarily selected to serve as a reference for evaluation. The model is based on the field data collected from these field plots and from rainfall simulation data (Simons and Senturk 1992). The empirical equation of the USLE is given as follows:

$$
A=R K L S C P
$$

where,

$$
\begin{aligned}
& A=\text { Soil loss in tones per unit area per year } \\
& R=\text { Rainfall and runoff erosivity index for a geographic location } \\
& K=\text { Soil Erodibility factor } \\
& L S=\text { Slope steepness and length (topographic) factor } \\
& C=\text { Cropping and management factor } \\
& P=\text { Erosion-control practices such as contouring or terracing }
\end{aligned}
$$

The computed soil loss $A$ has a time period of $R$ and soil loss dimensions of $K$. It has units of tones per unit area per year. A more detailed descriptions of the USLE equation and it's terms can be found in Smith and Wischmeier (1957) and Wischmeier and Smith (1978). The $L S, C$ and $P$ are all dimensionless. Values of each of the factors were estimated using field data and Agricultural Handbook No. 537 procedures and tables.

The $\mathrm{R}$ factor depends on the frequency distributions of annual, seasonal, or annualmaximum storms. It is predicted on a probability basis. In the Agriculture Handbook by Wischmeier and Smith (1978), an isoerodent map for average annual values of the 
rainfall erosion index is given. From the figure in the reference, $\mathrm{R}$ factor of 135 was used for the study area.

The $K$ factor, which is the soil erodibility factor, was found to be a function of percent of silt, percent of course sand, soil structure, permeability of soil, and percent of organic matter. The soil erodibility nomograph in Wischmeier and Smith (1978) is used to determine $K$ factor for top soils or subsoil horizons.

The LS - topographic factor was defined as the ratio of soil loss from any slope and length to soil loss from a 72.6 foot plot length at a nine percent slope, with all other conditions the same (Simons and Senturk 1992). The slope length is the distance from the point of overland flow origin to the point where either slope decreases to the extent that deposition begins or runoff water enters a well defined channel (Smith and Wischmeier 1957). The slope-effect chart was used to determine the $L S$ value for this study, yielding a $L S$ value of 0.32 in this study.

The cropping- management factor $C$ is defined as the ratio of soil loss from land cropped under specific conditions to corresponding loss from tilled, continuously fallow ground. The factor depends on type of vegetation cover, crop season and management techniques. Its value ranges between 0 and 1.0 approximately. Based on values used in similar studies a $C$ value of 0.28 was adopted for the two study ravines. 
The USLE predicts the gross soil loss from sheet and rill erosion per a unit area. To calculate the sediment yield per unit area, the USLE predictions must include the factors of delivery ratio and the watershed area. The sediment yield is given by the following equation:

$$
Y=\frac{E(D R)}{W s}
$$

where,

$$
\begin{aligned}
Y & =\text { Sediment yield in tones per unit area (tones per acre) } \\
E & =\text { Gross soil erosion in tones } \\
D R & =\text { Delivery ratio } \\
W S & =\text { Area of the watershed in acres }
\end{aligned}
$$

The delivery ratio $D R$ is the ratio of sediment delivered at a downstream point in the watershed to erosion from the area above that point. This ratio considers deposition in watershed and by definition is less than unity. The value of the delivery ratio can be approximated by estimating the amount of soil loss $A$, that will be deposited within a watershed depending on the nature of the land surface (Smith and Wischmeier 1957).

\section{Governing Equations of Gully Erosion Rate}

\section{Gully Width and Depth}

To study how the gully width and gully-bottom change according to the sediment budget, it is important to calculate the rate of change in width and depth during peak flows. The equations developed by Torri and Borselli (2003) link gully widening to gully deepening 
rates. The rate of change of gully width and depth during peak flows are expressed respectively as:

$$
\frac{\partial W}{\partial t}=\frac{q_{s}}{\rho D}
$$

where,

$\rho$ is the soil bulk density

$D$ is the gully depth and

$q_{s}$ is the sediment contribution from the side-walls per unit of channel length per unit of time

The gully depth changes due to the balance between deposition on and detachment from the gully bed. It is assumed that lateral sediment inputs are considered negligible with respect to the amount from the gully side-wall and bed during peak discharge - at the most important phase of concentrated erosion (Torri and Borselli 2003). The rate of gully depth change over time is then given by the following equation:

$$
\frac{\partial D}{\partial t}=\frac{1}{\rho} \frac{q_{B}-q_{S E D}}{W}
$$

Torri and Borselli (2003) presented an approach to gully erosion based on general equation derived from theoretical consideration. The derived equations link gully widening rate to gully deepening rate. 
For a fast and turbulent peak flow, it is assumed that the sedimentation velocity is nearly zero. Equations for $Q_{S E D}$ and $\frac{\partial D}{\partial t}$ are then modified for turbulent flow and the rate of depth change is given by the following equation:

$$
\frac{\partial D}{\partial W}=\frac{k_{b}}{2 k_{s} e_{f}}-\frac{D}{W}
$$

The $k_{s}$ and $k_{b}$ coefficients indicate soil erodibility and $e_{f}$ is an efficiency parameter defined as the ratio between the force exerted by the flow on the walls and force exerted on the bed. Calculating the exact value of an efficiency coefficient is important but complicated. Torri and Borselli (2003) suggest that the efficiency coefficient as a function of the ratio between channel width and water flow depth can be read from a graph of $e_{f}$ and $W / h$ plot given by (Chow 1973). Figure 13 shows the efficiency coefficient graph.

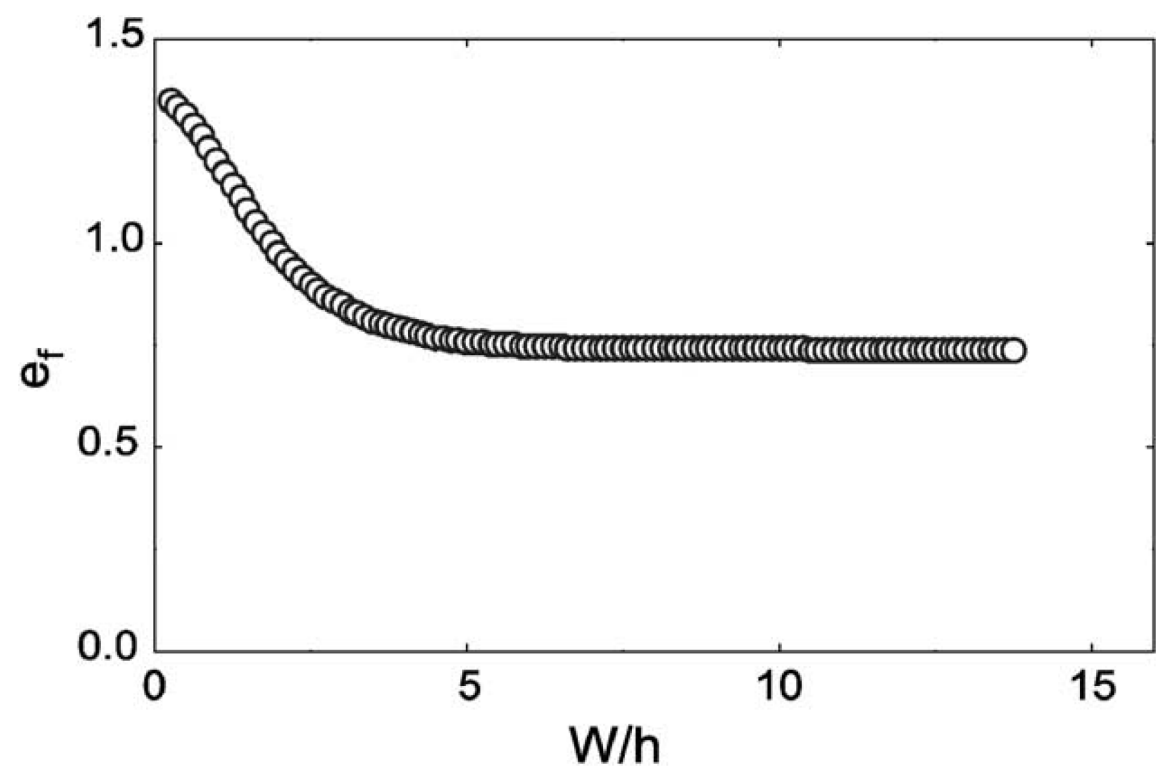

Figure 13. Efficiency coefficient as a function of the ration between channel width and water flow depth from Chow (1973).

Adopted from (Torri and Borselli 2003) 
Torri and Borselli (2003) also suggest that using the Laplace polynomial expansion technique, one solution to the above equation can be given as:

$$
D-D_{o}=\frac{k_{B}}{4 k_{s} e_{f}}\left(W-W_{o}\right)
$$

where,

$D_{0}$ and $W_{0}$ are the depth and width reached before the flow starts digging the soil layer characterized by the erodibility $k_{b}$ and $k_{s}$.

It is important to note that the above equation holds during peak flow. For later erosion developments, the relationship between width and depth need to be modified. Furthermore, the flow aggressiveness $p$, which is any measure of flow erositivity is given using two of the most commonly used estimators, the stream power and flow shear stress. Torri and Borselli (2003) provide the equations for flow aggressiveness using the equations for gully bed and walls as follows:

Assuming $p$ is unit stream power,

$$
p(t)=\frac{p_{A} g Q \sin \gamma}{W(t)}
$$

where,

$p_{A}$ is water density, $\mathrm{g}$ is acceleration due to gravity, and $\gamma$ is the local slope angle, assuming $\mathrm{p}$ is a unit stream power.

The rate of change of gully width is then modified to be:

$$
\frac{\partial W}{\partial t}=\frac{2 k_{S}\left(e_{f} \rho_{A} g Q \sin \gamma-W p_{c r}\right)}{\rho W}=\frac{C_{s p} Q \sin \gamma}{W}-\frac{2 k_{s} p_{c r}}{\rho}
$$


where,

$C_{s p}$ is a composite parameter, it has a dimension of $\left[\mathrm{L}^{-1}\right]$ and it is given as:

$$
C_{s p}=\frac{2 k_{S} e_{f} \rho_{A} g}{\rho}
$$

Assuming the term $2 k_{s} p_{c r} / \rho$ is small with respect to the first addendum, the above equation simplifies in to:

Notation

$$
W=\sqrt{C_{s p} \sin \gamma \int_{\Delta t_{e f f}} Q d t+W_{0}^{2}}
$$

where,

$W_{0}$ is the channel width before peak discharge, and $\Delta \mathrm{t}_{\text {eff }}$ is the time interval during which the flow is erosive and close to peak discharge.

These sediment load equations were solved by an iterative scheme for each time step of the available flow data. 


$\begin{array}{llc}D & \text { Initial depth of gully } & \text { meter } \\ W & \text { Initial width of gully } & \text { meter } \\ Q & \text { Water Flow rate } & \mathrm{m}^{3} \mathrm{~s}^{-1} \\ \rho & \text { Soil bulk density. } & \mathrm{kg} \mathrm{m}^{-3} \\ \gamma & \text { Local slope angle } & \text { Percent } \\ n & \text { Manning's roughness coefficient } & -- \\ Q_{I N} & \text { Sediment from upstream entering the gully } & \mathrm{kg} \mathrm{day}^{-1} \\ Q_{O U T} & \text { Sediment leaving the gully. } & \mathrm{kg} \mathrm{day}^{-1} \\ Q_{L} & \text { Sediment from uplands entering the gully. } & \mathrm{kg} \mathrm{day}^{-1} \\ C_{S p} & \text { Composite parameter } & \mathrm{m}^{-1} \\ k_{S} & \text { Coefficient of soil erodibility of gully walls } & \mathrm{day}^{2} \mathrm{~m}^{-2} \\ k_{B} & \text { Coefficient of soil erodibility of gully bed } & \mathrm{day}^{2} \mathrm{~m}^{-2} \\ e_{f} & \text { Efficiency coefficient }- \text { the ratio between the } & ---\end{array}$

Input Requirements

All parameters required by the model to simulate the sediment budget change and soil loss from the ravines are summarized in Table 3 .

Table 3. Model input parameters 


\section{Model Assumptions and Limitations}

- The model is limited to the processes of incision and widening only.

- Lengthwise growth of the gully system is assumed to be negligible within single runoff event. Hence gully headcut retreat rate is not computed.

- Cross-stream variations induced by cross-section geometrical features such as constrictions or expansions or obstructions by woody debris or rocks are neglected.

- The channel is assumed to be prismatic.

- Further work is needed to involve the capability to simulate erosion in branching gully systems.

\section{Characterization of Coefficient of Soil Erodibility}

The coefficients of soil erodibility of both gully-wall and gully-bed are normally determined in the field. However, due to the lack of existing field data, an alternative approach was followed in which numerical estimation was done using the Meyer-Peter and Muller (1948) formulation for bed load transport. The Meyer-Peter and Muller estimates of the sediment load from the gully bed were compared with the estimates given by Torri and Borselli's equation of $Q_{B}$ and a $k_{B}$ value was calculated. According to (Meyer-Peter and Müller 1948) formulation valid for sediment diameters between 0.23 and $28.6 \mathrm{~mm}$, the bed load sediment discharge $Q_{S}$ is given as:

$$
\begin{array}{r}
Q_{S}=8 \frac{1}{\rho^{1 / 2}} \frac{1}{\left(\gamma_{s}-\gamma\right)}\left(\tau_{b}-\tau\right), \text { when } \tau_{b} \geq \tau_{c} \\
Q_{S}=0, \quad \text { when } \tau_{b} \leq \tau_{c}
\end{array}
$$


$\tau_{b}$ is the bed shear stress computed as:

$$
\tau_{b}=\frac{n^{2} \gamma}{h^{1 / 3}}\left(U^{2}-V^{2}\right)
$$

And $\tau_{c}$ is the critical shear stress given as:

$$
\tau_{c}=0.047\left(\gamma_{s}-\gamma\right) D_{m}
$$

Figure 14 shows the estimation of the coefficient $k_{b}$, by close matching the estimates of gully bed sediment load between the unit stream power formulation, equation (12) with the estimate using the Meyer-Peter and Muller equation (15).

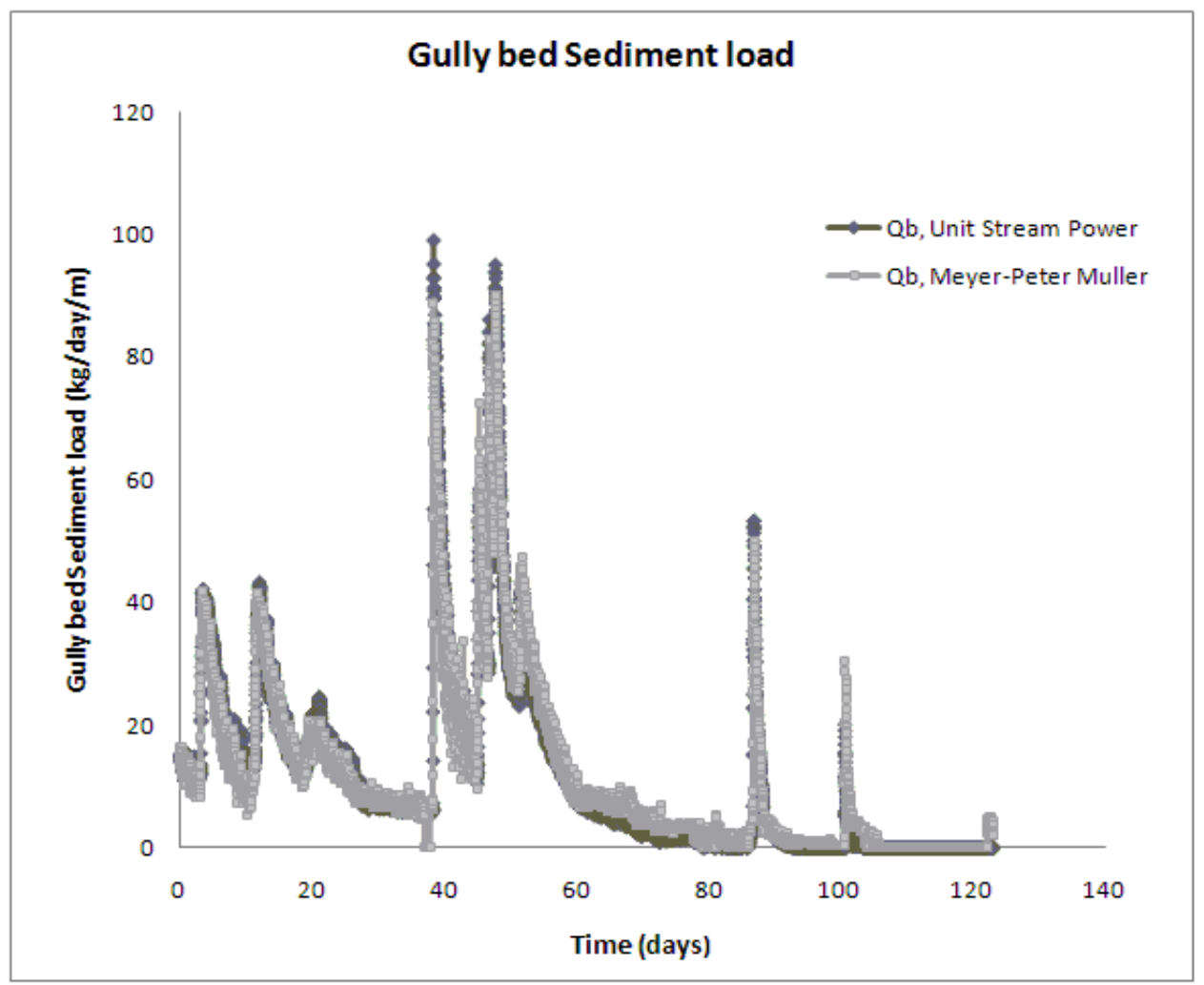

Figure 14. Ravine bed sediment load calculation. Using Torri and Borcelli's unit stream power and Meyer-Peters and Muller equations 
To study how well the $\mathrm{Q}_{s}$ estimates using the two approaches matches, a best-fit regression line is plotted in Figure 15. The slope of the regression line indicates the relative relationship between the two $\mathrm{Q}_{s}$ estimates. This resulted in a "best match" that yields a coefficient of soil erodibility of $k_{B}=1.97 \times 10^{-16}$ day $^{2}$ meter $^{-2}$. Moreover, to study the relationship between cross-section and gully width, Torri and Borselli (2003) introduce a ratio $R$ which is defined as the ratio of $k_{s}$ to $k_{B}$. If the ratio $R$ is characterized by a sufficiently large standard deviation, the relation between gully cross section and width can be described by linear equations. $R$ value of $1 \pm 0.35$ was used in the reference; a ratio of 1.35 was adopted in this study hence $k_{s}=1.35 k_{B}$.

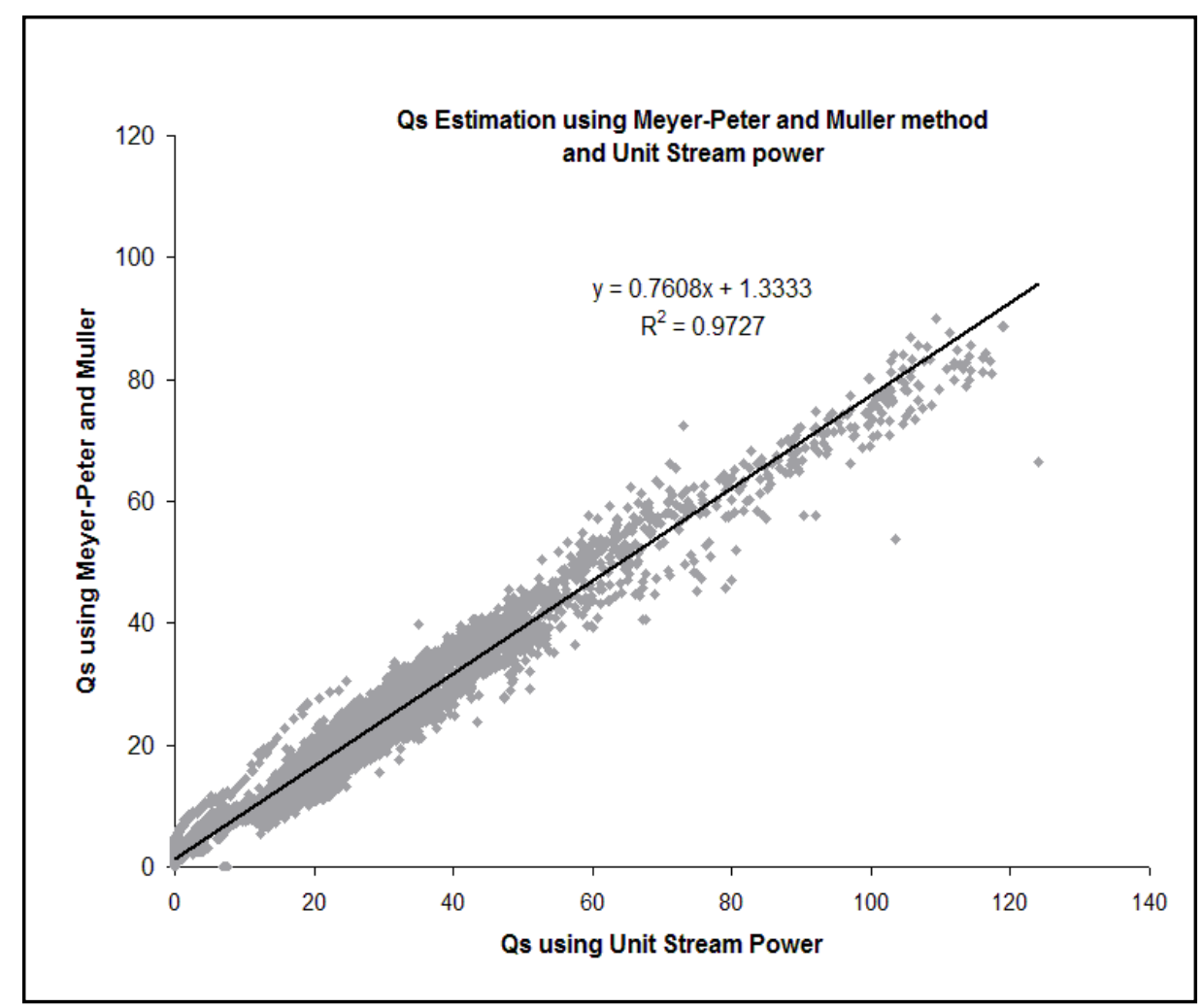

Figure 15. Comparison of the fits of the two equations for estimating sediment load from gully bed. 
Model efficiency was calculated following the approach given by Nash and Sutcliffe (1970). The Nash-Sutcliffe efficiency (NSE) is an indicator of model performance. NSE is a normalized statistic that determines the relative magnitude of the residual variance ("noise") compared to the measured data variance ("information")(Nash and Sutcliffe 1970). NSE indicates how well the plot of observed versus simulated data fits the 1:1 line (Moriasi et al. 2007). NSE is computed as shown in the equation below:

$$
N S E=1-\left[\frac{\sum_{i}^{n}\left(Y_{i}^{\text {obs }}-Y_{i}^{\text {sim }}\right)^{2}}{\sum_{i}^{n}\left(Y_{i}^{\text {obs }}-Y_{i}^{\text {mean }}\right)^{2}}\right]
$$

where,

$\mathrm{Y}_{\mathrm{i}}^{\text {obs }}$ is the $i$ th observation for the constituent being evaluated $\mathrm{Y}_{i}^{\text {sim }}$ is the $i$ th simulated value for the constituent being evaluated $\mathrm{Y}_{i}^{\text {mean }}$ is the mean of observed data for the constituent being evaluated $\mathrm{n}$ is the total number of observations.

NSE values range between $-\infty$ and 1.0, where efficiency of 1.0 indicates a perfect match of the simulated value to the observed data and efficiency values of $\leq 0.0$ indicates that the mean observed value is a better predictor than the simulated value, hence unacceptable performance (Moriasi et al. 2007). 


\section{CHAPTER IV. RESULTS AND DISCUSSION}

\section{Case Study}

Once developed, the model theoretical framework needed to be verified using a dataset from the literature. In this study, the dataset used in the research of Thomas et al. (2004) was used to build case study simulations in the model. The study was carried out on valley-bottom gully in western Iowa to estimate the annual growth rate of a permanent gully over 30 years. The gully was mapped and surveyed several times during the 30 year time. Daily discharges of water and suspended sediment through the gully were also recorded nearly continuously for over 36 years. The flow and suspended sediment data of the study site in Iowa was obtained directly from the authors of this reference. Using the monthly average flow and TSS data, the gully erosion model was then run for a time period of $1964-2000$.

Application of the model yielded estimates for total soil loss from the valley bottom gully, change in gully width, depth and bank slope that agreed reasonably well with the estimations from the referenced literature. Comparison of model outputs with the estimates given in the referenced literature is shown in the plots presented in Figure 16. The modeled values were plotted against the data obtained from the literature. The mean gully width estimates were on an average within $99 \%$ of those reported in the literature, with a difference ranging between $-2 \%$ to $5 \%$. The corresponding $\mathrm{R}^{2}$ value is 0.89 . The mean gully depth estimates have a difference of $-0.4 \%$ on average and ranging between $-17 \%$ to $13 \%$. Differences were larger for the gully bank slope: $-5 \%$ on an average and raging between $-5 \%$ to $15 \%$. 

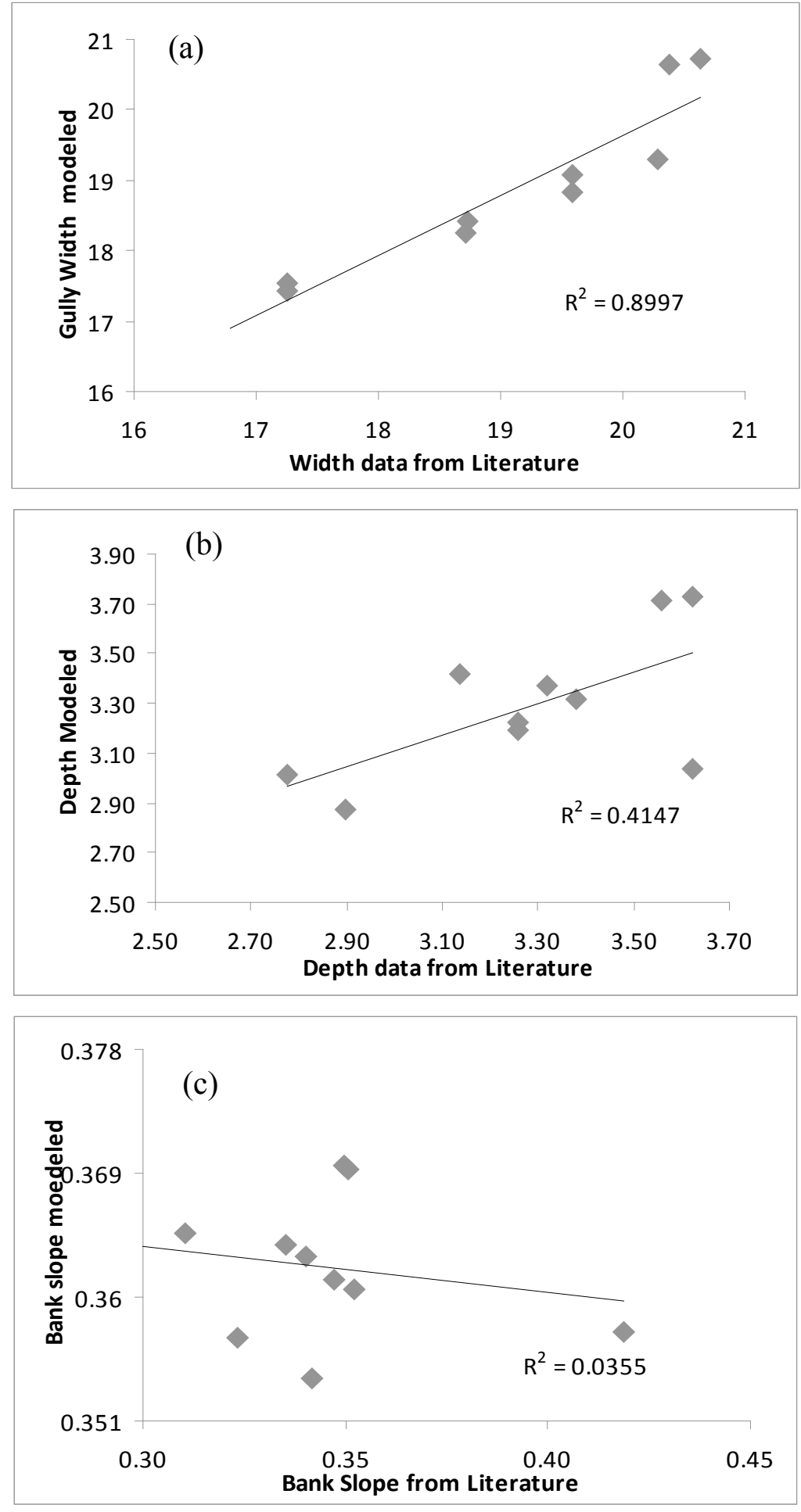

Figure 16. Comparison of modeled and observed (a) gully width, (b) gully depth and (c) bank slope. 
For gully width, depth and bank slope simulations the Nash-Sutcliffe efficiency (NSE) was calculated as an indicator of performance. Agreement between model estimations of gully width and estimates in the referenced literature corresponds to model efficiency of 0.94. But model efficiency was low for depth and bank slope simulations. (0.30 for gully depth and -0.05 for bank slope). Figures 16-19 show the results of the model application (Model) and comparison with field results (Data) reported in Thomas et al. (2004).

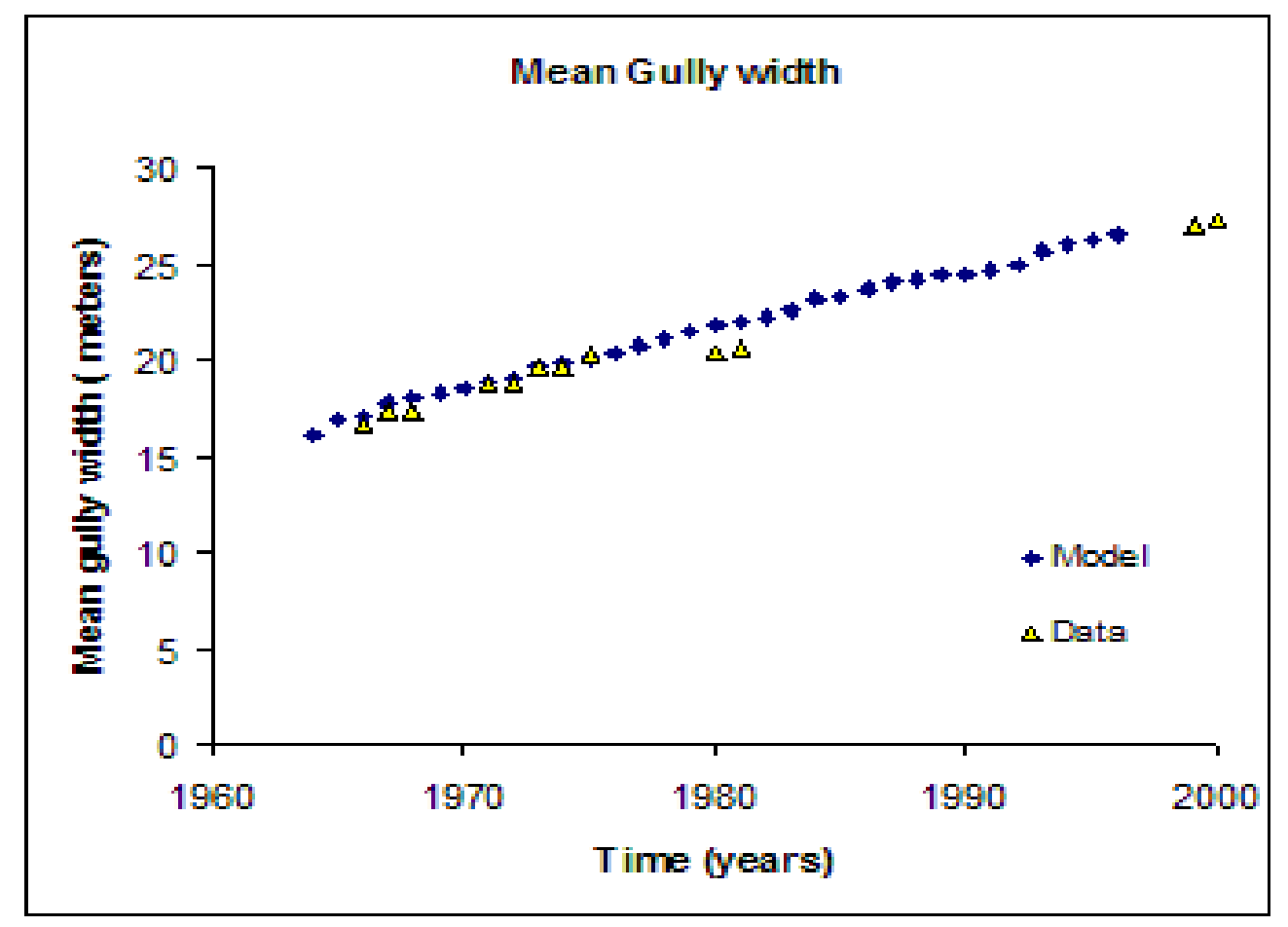

Figure 17. Mean gully width growth over time 


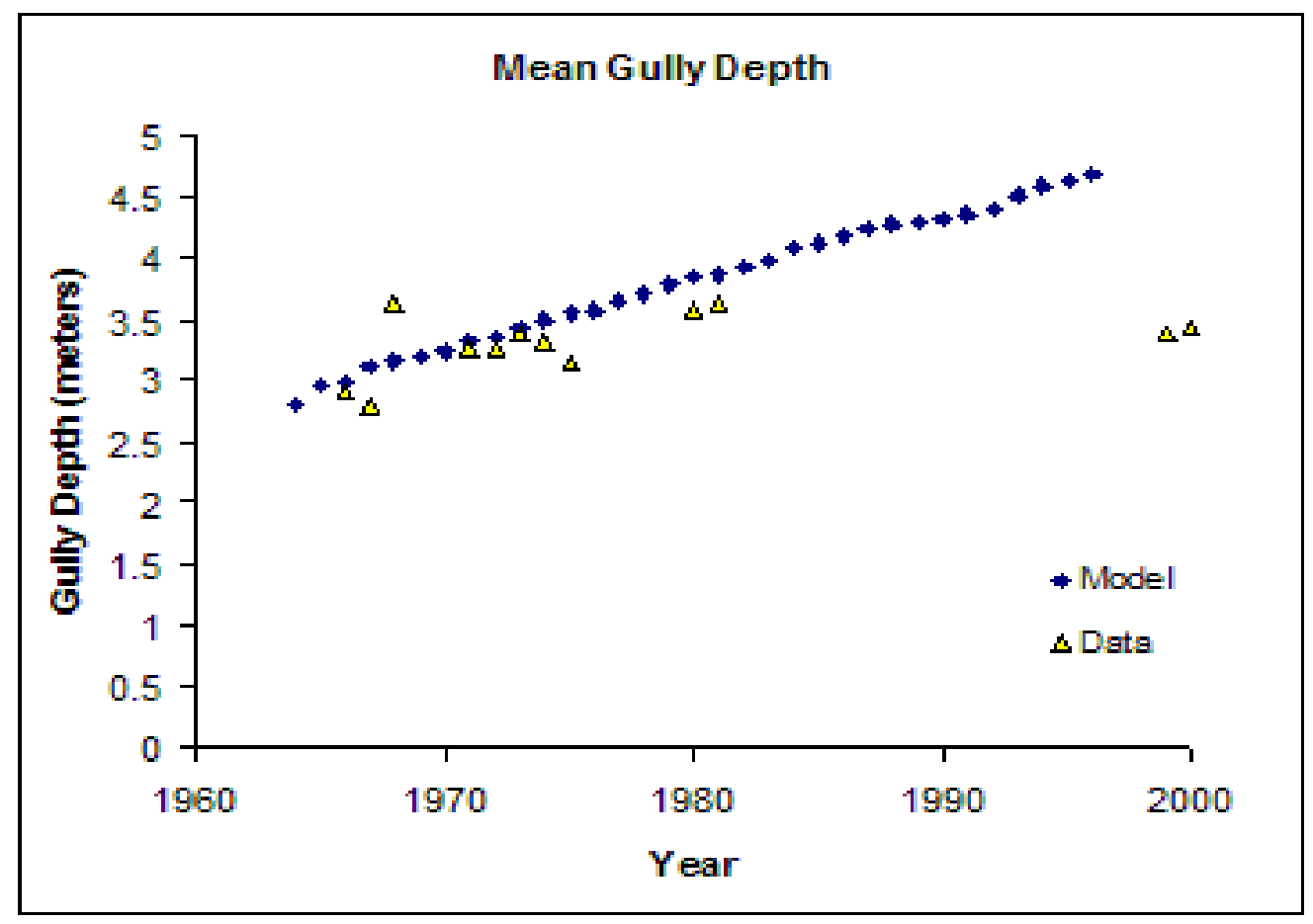

Figure 18. Mean gully Depth over time

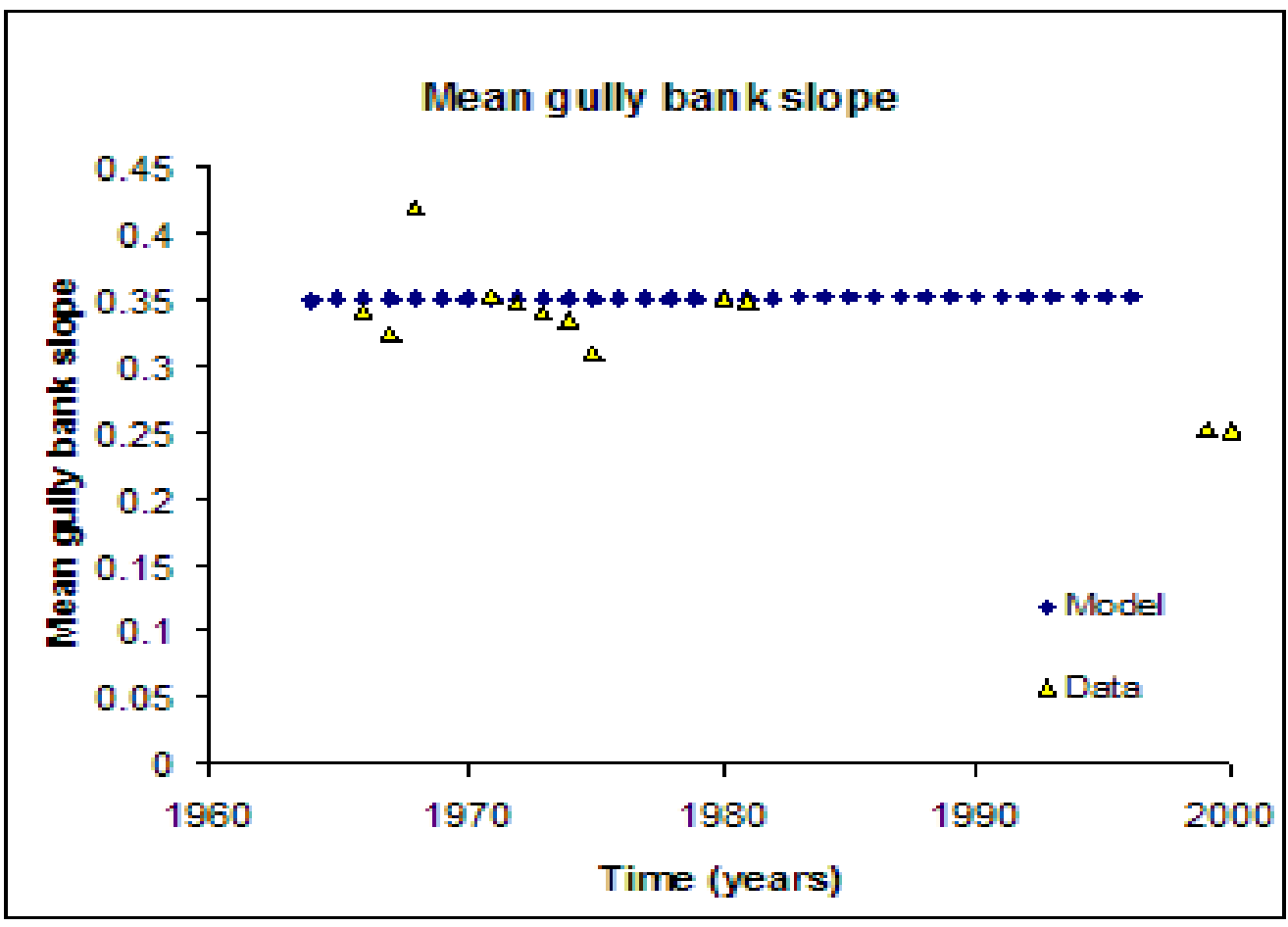

Figure 19. Mean Gully bank slope over time 
Moreover, model estimates for the total sediment yield of the gully were approximately equivalent to the values reported in the literature. Thomas et al., (2004) estimates that an average of $3.2 \times 10^{5} \mathrm{~kg}$ of sediment removed from the gully annually. Model estimates were $3.21 \times 10^{5} \mathrm{~kg}$ of sediment per year.

The simulated mean monthly growth rate and the mean monthly runoff have a power relation which is in agreement with the rates calculated in the referenced literature. However the relation in the model simulation is slightly different than the once calculated in the literature (Figure 21).

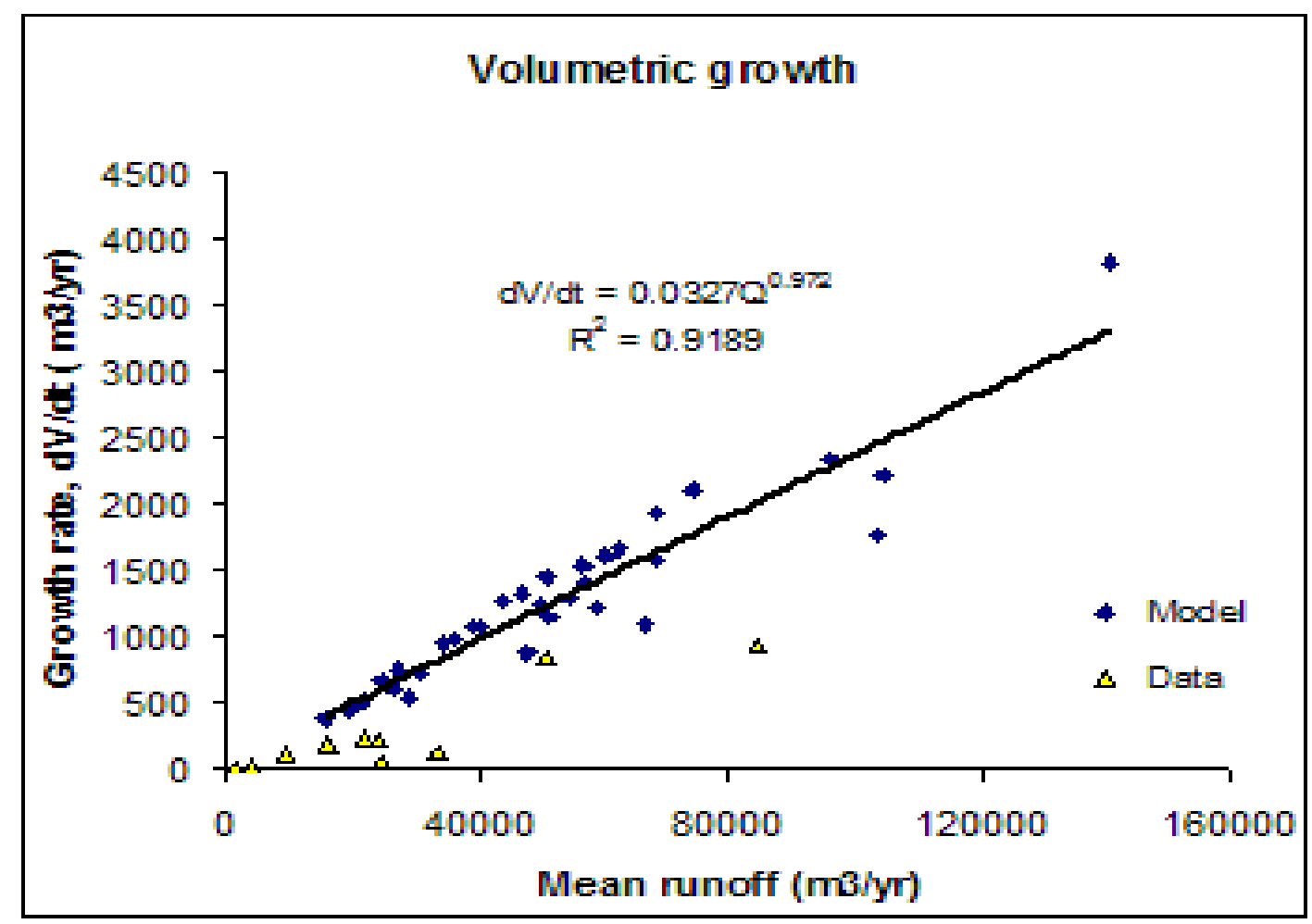

Figure 20. Volumetric growth of gully versus water discharge. 


\section{$\underline{\text { Model Estimations for Study Ravines }}$}

After the model was running well for the test case in Thomas et al. (2004), the available sediment and flow data of the two study ravines in the Le Sueur watershed was used to simulate the growth rate, width and depth change of the CR-8 and CR-90 ravines. The results are presented in the plots of Figures 21 and 22.

\section{Ravine CR-90}

The simulation of the ravine width and depth change of Ravine CR-90 shows that the storm events during April - October 2008 had triggered a very small increase in both gully width and depth. Though in small magnitude, the ravine increased in width rather than incised. The rate of change of gully depth is mostly negative for CR-90 implying there is deposition or temporary sediment storage within the ravine.

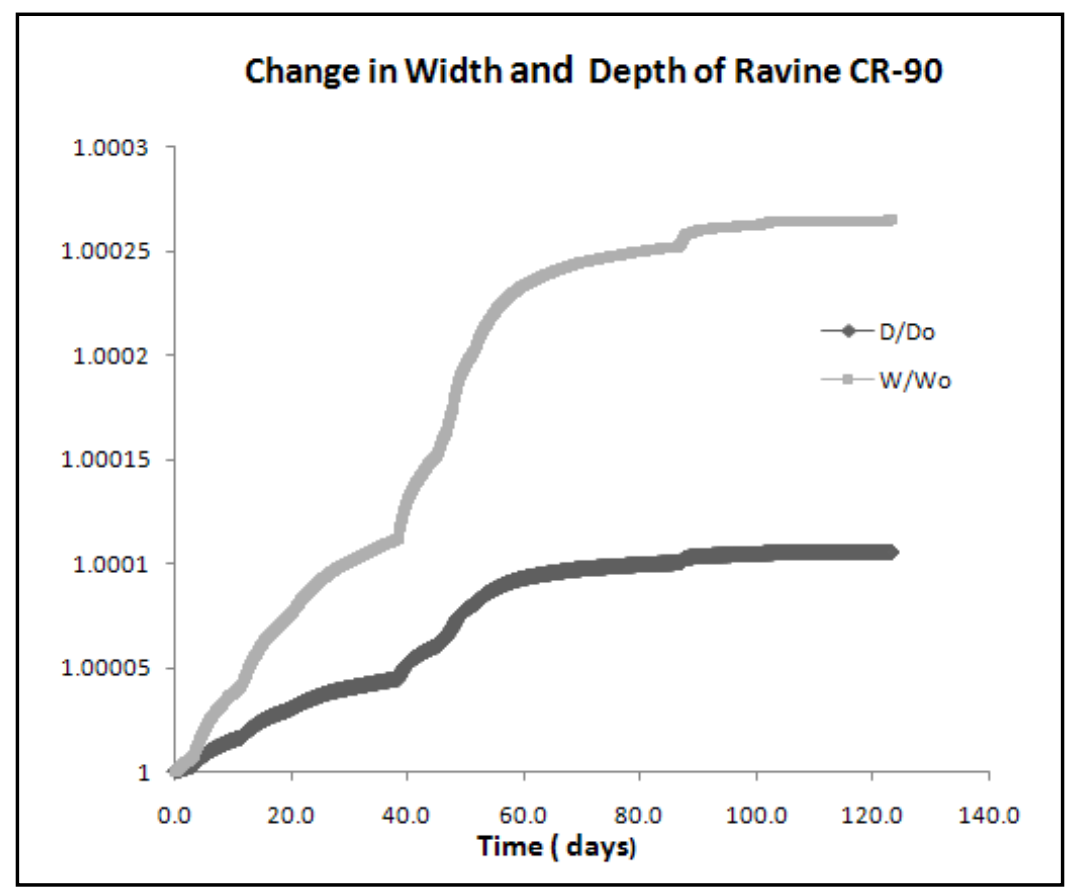

(A) Change in width and depth of ravine CR-90. 


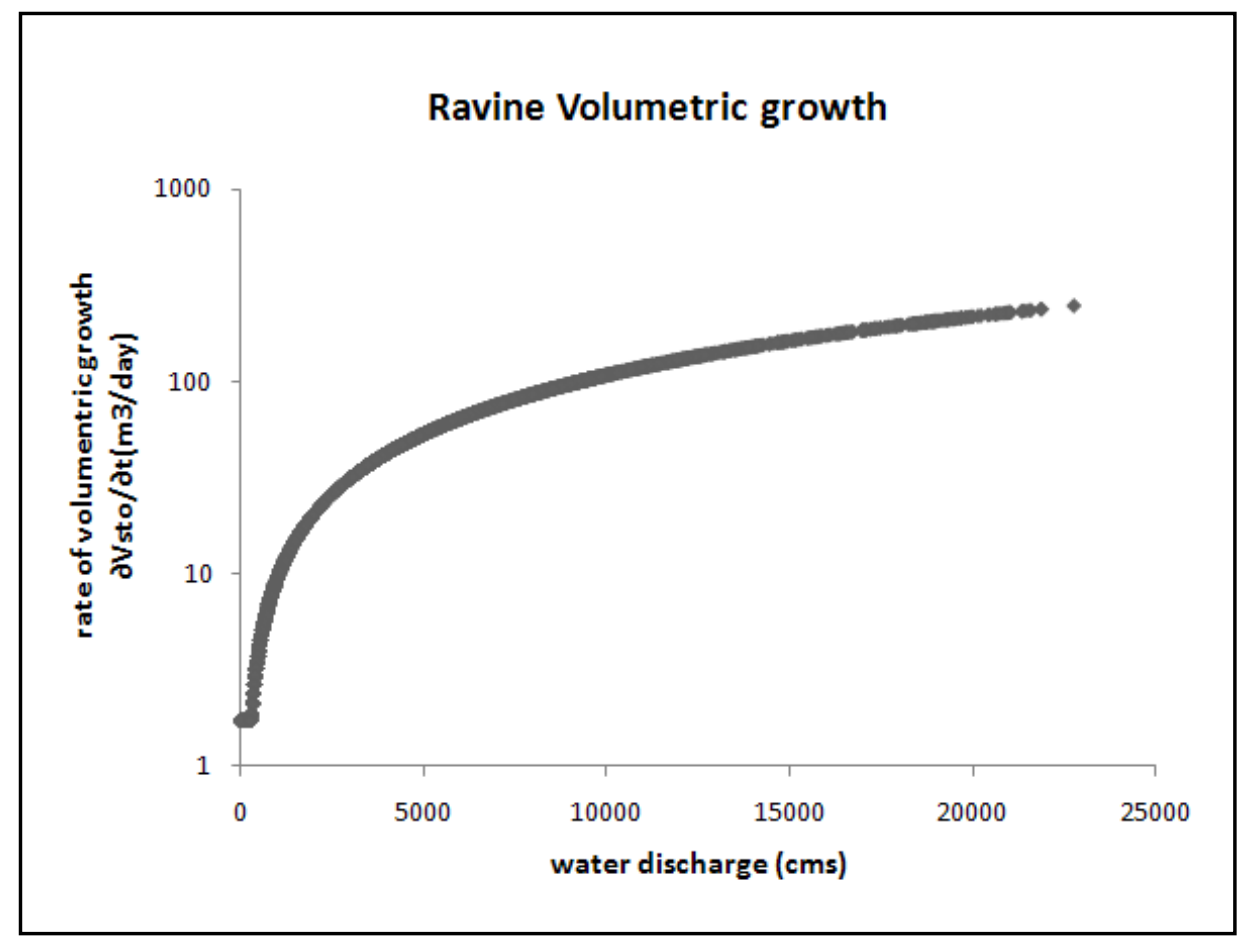

(B) Estimation of Volumetric growth of ravine CR-90

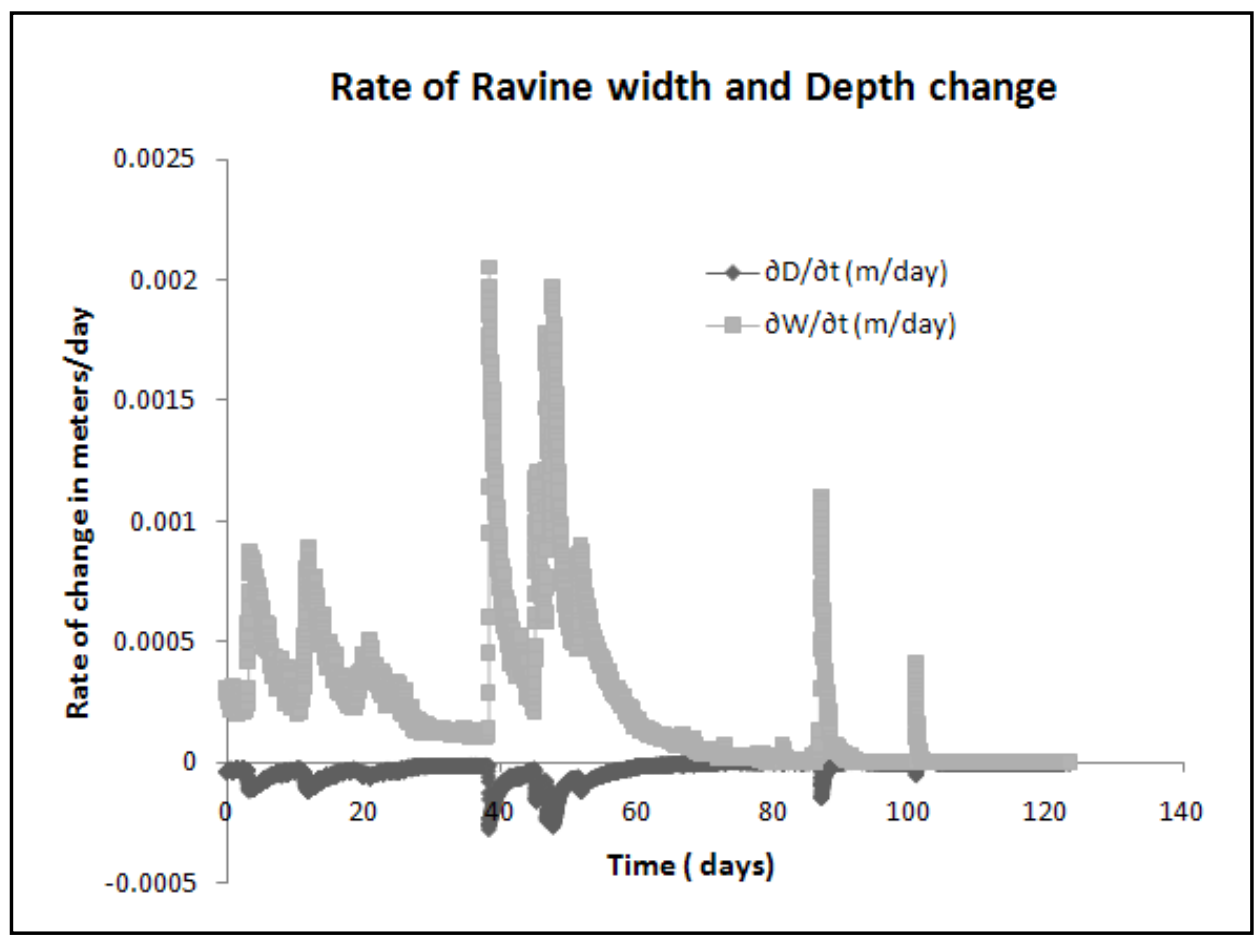

(C)Rate of ravine width and depth change of ravine CR-90

Figure 21. Model simulations for CR-90 


\section{Ravine $C R-8$}

The change of mean width and depth of Ravine CR-8 is different than CR-90 that the ravine seems to be increasing in depth and width in approximately the same magnitude. The rate of depth change is positive for this ravine, which shows the ravine is incising. But in both cases the magnitudes of change is small for the measured storm events of summer 2008 .

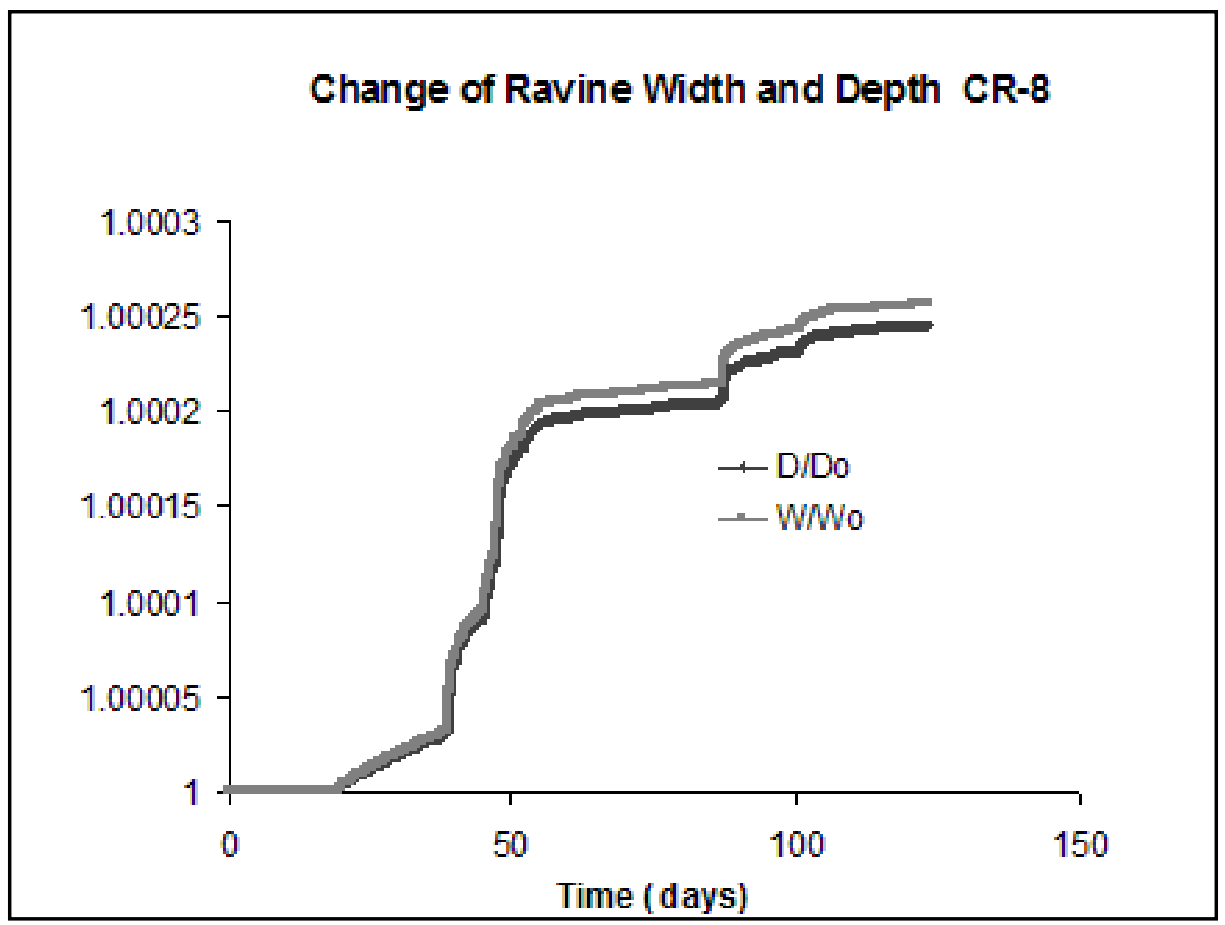

(A) Change of width and depth of ravine CR-8 


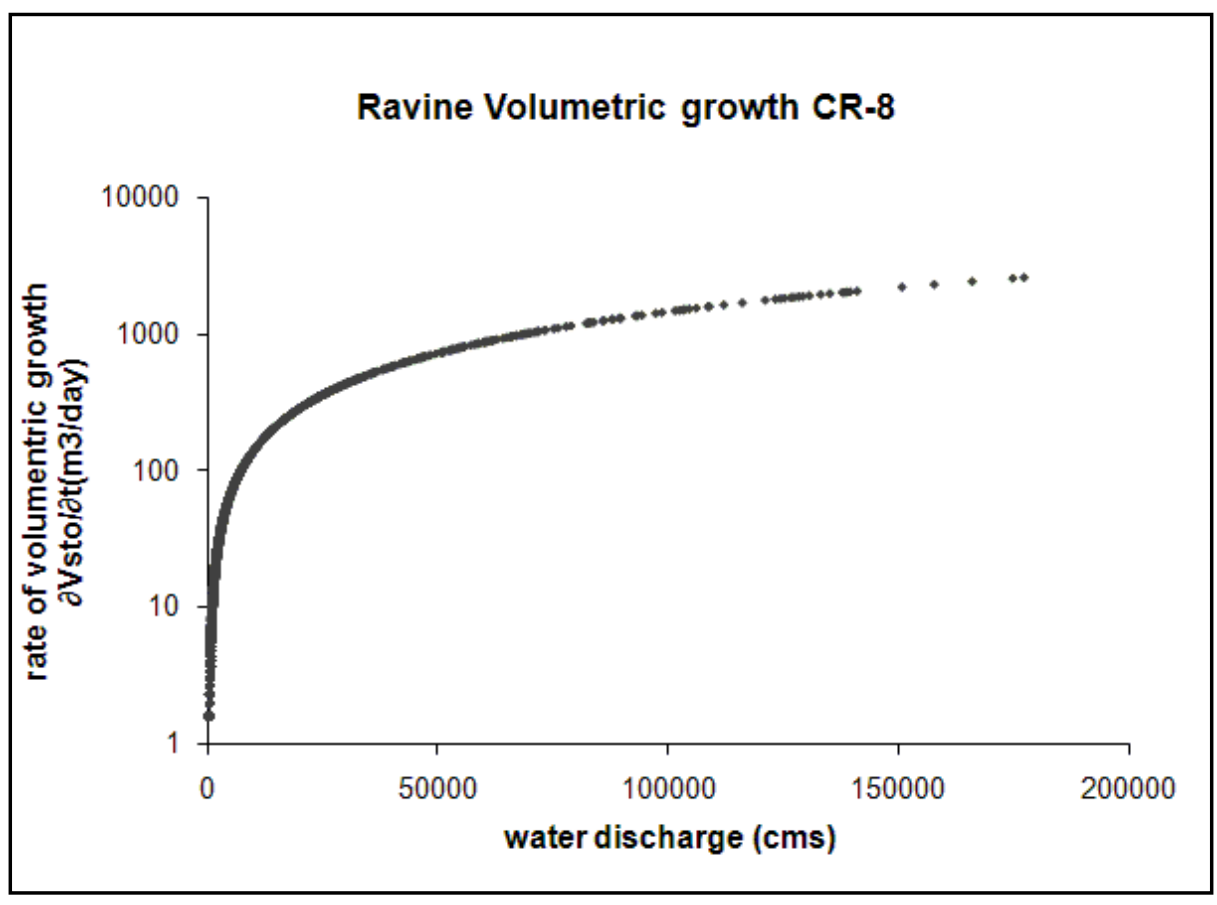

(B) Volumetric growth of ravine $C R-8$

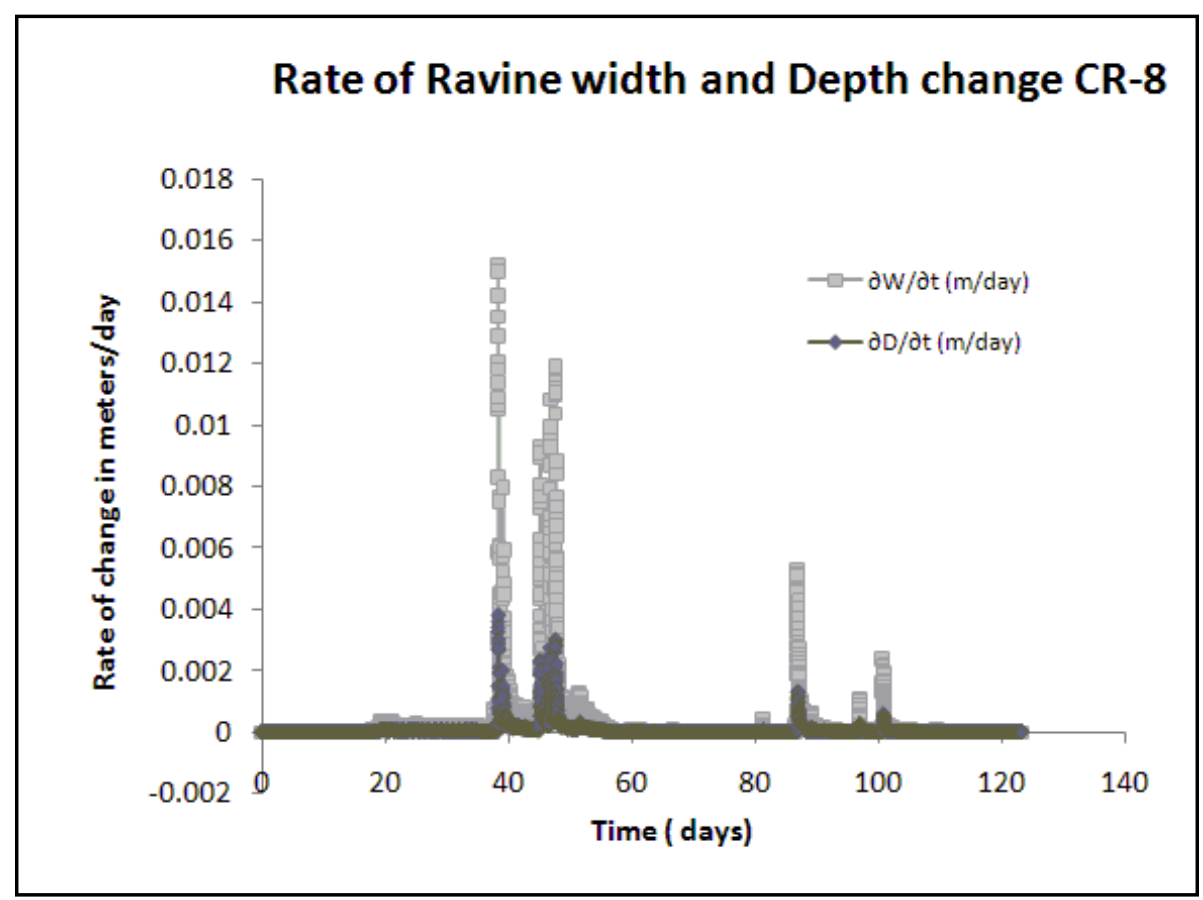

(C)Rate of change of ravine width and depth of Ravine CR-8

Figure 22. Model Simulations for ravine CR-8 
Table 4 summarizes the model estimates of sediment contribution of each sediment sources, and the total sediment loading of the study ravines during the period of April October 2008. The sediment yield of ravines is calculated using the ravine area and the total sediment loading.

Table 4. Summary of Sediment loading and sediment contribution of sources inside ravines.

Description

Drainage area (acres)

Ravine area (acres)

\section{Sediment budget (kg)}

Sediment contribution from ravine walls

Sediment contribution from ravine bed

Sediment contribution from upstream

Sediment contribution from uplands

Sediment deposited in ravine

Total sediment loading to Le Sueur (kg)

Ravine yield (kg/ha)

Percentage of upland driven sediment

Percentage of Ravine driven sediment
Ravine CR-90

994

56

80

961

Ravine CR-8

162,438

77,478

$53.4 \%$

$32.8 \%$

133,811

152,963

$44.0 \%$

$64.7 \%$

0

0

0\%

$0 \%$

8,198

5,916

$2.7 \%$

$2.5 \%$

162,438

77,478

$53.4 \%$

$32.8 \%$

141,997

158,871

6,213

4,883

$6 \%$

$4 \%$

$94 \%$

$96 \% 1$

\footnotetext{
${ }^{1}$ The sediment load estimates are for the period April - October 2008, where measurements were taken.
} 


\section{$\underline{\text { Sensitivity Analysis }}$}

In order to assess the relative importance of each variable, a sensitivity analysis was conducted to study the effect that a change in the input would cause to the model output. The sensitivity of the model to the various parameters was evaluated by increasing and decreasing the input parameter values by $50 \%$. The relative changes in total sediment yield associated with these perturbations are then listed in Table 5 in a decreasing order of their sensitivity. Quantify the degree of sensitivity of each parameter, an expression for sensitivity coefficient $S$ used by McCuen and Snyder (1986) was selected for its simplicity and applied in this study. The sensitivity coefficient $\mathrm{s}$ is the ratio of the relative output change to the relative input change. The following equation describes the sensitivity ratio.

$$
S=\left(\frac{O_{2}-O_{1}}{O_{\overline{12}}}\right)\left(\frac{I_{2}-I_{1}}{I_{\overline{12}}}\right)^{-1}
$$

where,

$$
\begin{aligned}
& O_{2} \quad=\text { Output of model using input parameter of maximum value of } I_{2} \\
& O_{1} \quad=\text { Output of model using input parameter of minimum value of } I_{1} \\
& O_{\overline{12}} \quad=\text { Average of the Out puts } O_{1} \text { and } O_{2} \\
& I_{\overline{12}} \quad=\text { Average of the Out puts } I_{1} \text { and } I_{2}
\end{aligned}
$$

Baffaut et al. (1997) explains that the sensitivity index obtained using the above method is independent of the magnitude of the input and the output, hence it can be used to compare the sensitivity of the model to different variables but it does not account for interaction between variables. This study, however, is limited to the broad assumption 
that the parameters are independent of each other. The analysis performed using equation (19) is intended to provide an estimate of the sensitivity of the simulation results to the model parameters.

Two sensitivity coefficients using both the minimum and maximum values of the input parameters were evaluated for each input parameter and $S$ values are also listed in Table 5. (The minimum input value is assumed to be $50 \%$ of the defined value and a maximum value as $50 \%$ more of the defined value).

Sediment derived from the gully sides was responsible for about $55 \%$ of the total sediment yield in this gully. Hence, parameters related to these sources have higher sensitivity to the model output. One of the most important parameters is the erodibility coefficient of the gully bed. However, this parameter is also sensitive to the manning's coefficient- $\mathrm{n}$ as it was estimated using the Meyer-Peter and Muller equations for bed load transport. 
Table 5. Parameterization of the erosion model and sensitivity analysis of its parameters.

\begin{tabular}{|c|c|c|c|c|c|c|c|}
\hline \multirow[t]{2}{*}{ Notation } & \multirow[t]{2}{*}{ Description } & \multirow[t]{2}{*}{ Units } & \multirow[t]{2}{*}{$\begin{array}{l}\text { Initial } \\
\text { value }\end{array}$} & \multicolumn{2}{|c|}{ Sensitivity coefficient } & \multicolumn{2}{|c|}{$\begin{array}{c}\text { Change(\%) in soil loss after } \\
\text { change of }\end{array}$} \\
\hline & & & & $S_{50 \%}$ & $S_{-50 \%}$ & $50 \%$ & $-50 \%$ \\
\hline$n$ & Manning's roughness coefficient & --- & 0.04 & 2.52 & 2.06 & $204 \%$ & $-82 \%$ \\
\hline$k_{B}$ & $\begin{array}{l}\text { Coefficient of soil erodibility of } \\
\text { gully bed }\end{array}$ & & $1.97 \mathrm{E}-16$ & 0.95 & 0.93 & $47 \%$ & $-47 \%$ \\
\hline$p_{c r}$ & Critical flow aggressiveness & & $1.05 \mathrm{E}+14$ & -0.10 & -0.06 & $-4 \%$ & $4 \%$ \\
\hline$k_{S}$ & $\begin{array}{l}\text { Coefficient of soil erodibility of } \\
\text { gully walls }\end{array}$ & & $2.66 \mathrm{E}-16$ & 0.00 & 0.00 & $0 \%$ & $0 \%$ \\
\hline$e_{f}$ & Efficiency coefficient & --- & 0.7 & 0.00 & 0.00 & $0 \%$ & $0 \%$ \\
\hline \multicolumn{8}{|c|}{ Ravine dimensions } \\
\hline$\gamma$ & Local slope angle & degrees & 0.31 & 0.91 & 0.91 & $44 \%$ & $-47 \%$ \\
\hline$L$ & Stream length & Meter & 3760 & -0.05 & -0.08 & $-2 \%$ & $6 \%$ \\
\hline$D$ & Initial depth of gully & meter & 40 & 0.00 & 0.00 & $0 \%$ & $0 \%$ \\
\hline$W$ & Initial width of gully & meter & 60 & 0.00 & 0.00 & $0 \%$ & $0 \%$ \\
\hline \multirow[t]{2}{*}{$\rho$} & Soil bulk density. & $\mathrm{kg}_{\text {day }}{ }^{1}$ & 1510 & --- & --- & --- & --- \\
\hline & Gully bank slope & percent & 1.33 & 0.00 & 0.00 & $0 \%$ & $0 \%$ \\
\hline \multicolumn{8}{|c|}{ Upland Driven erosion } \\
\hline$Q_{L}$ & $\begin{array}{l}\text { Sediment from uplands entering } \\
\text { the gully. }\end{array}$ & tones year ${ }^{-1}$ & 951 & 0.07 & 0.04 & $3 \%$ & $-3 \%$ \\
\hline$T S S_{I N}$ & $\begin{array}{l}\text { Sediment from upstream entering } \\
\text { the gully }\end{array}$ & mg litre $^{-1}$ & 142.355 & 0.00 & 0.00 & $0 \%$ & $0 \%$ \\
\hline$T S S_{\text {OUT }}$ & Sediment leaving the gully. & mg liter ${ }^{-1}$ & 31.053 & 0.00 & 0.00 & $0 \%$ & $0 \%$ \\
\hline
\end{tabular}




\section{CHAPTER V. CONCLUSIONS}

This study has presented a numerical model for quantifying soil loss from two gauged study ravines in the lower Le Sueur River, Minnesota. Despite the simplification, it was possible to compare the model estimations with data from literature. An investigation of a case study in a gully system in Iowa (Thomas et al., 2004) using the numerical model developed in this thesis yielded estimates for total soil loss and rates of change of gully morphology that agreed reasonably well with the estimations from the referenced literature.

The results presented in the previous chapters lead to answers to the research questions posed in Chapter I. The modeling results suggest that about $94 \%-96 \%$ of the sediment loading to the Le Sueur from the two study ravines originate inside the ravines. The ravines act as a link connecting the uplands (of which agriculture is the main activity) and the main river stem. However, the model estimates of the contribution of the sediment derived from the uplands and routed through the ravines are minimal when compared to the sediment produced from the sources inside the ravines.

In this study, it was also possible to identify the sediment sources and quantify the sediment budget of the study ravines. Field observations showed that there are a number of eroding bluffs and terraces inside ravines which are the major sediment sources in the ravine. This was in agreement with the model estimations of the sediment budget. The sediment budget was calculated as the difference between the sediment storages and sediment fluxes from the agricultural fields, ravine side walls and ravine bed. In ravine 
CR-90, the major sediment source was the ravine walls, contributing $54 \%$ of the total sediment yield and $44 \%$ was derived from the ravine bed. For ravine CR- $8,65 \%$ of the total sediment yield was derived from the ravine bed and ravine bed erosion contributed $33 \%$.

TSS data from the two monitoring gauges show extremely short-lived, very high sediment loads to the Le Sueur River. Direct discharge of water to ravine increases erosion activity inside ravine. Plunge pools are noticed at the outlet of the tile drainages and points of entry of overland flow. Moreover, the concentrated flow created deep incisions along the walls of the ravine causing amass wasting of the steep ravine valley walls.

Furthermore, it was noted that the ravines are widening at a higher rate rather than incising. There were no data available to compare the rates of change of the ravine width and depth. However, the model was able to give an idea on how the width and depth have changed during the storm events of April to October 2008. 


\section{CHAPTER VI. RECOMMENDATIONS}

This research is expected to serve as the gateway for investigations into the ravine sediment contribution to the total sediment budget of the Le Sueur River watershed. This study focused on modeling only two of the gauged ravines in the lower reaches of the river, and fundamentally aimed at quantifying the sediment budget using the available data from the gauges. However, there are more than 90 ravines in the river watershed and gauging these ravines is prohibitively expensive. Hence, the results and conclusions drawn from this research will be extrapolated to the ravines throughout the river watershed so that more accurate ravine sediment loading to the river can be accounted in the sediment budget of the Le Sueur River watershed.

The model is limited to the processes of incision and widening only. However, lengthwise growth of the gully system within single runoff event should be considered to better understand the ravine change over time. Another assumption made in this study is that the ravine channel is considered to be prismatic and with uniform cross section. However, the cross-stream variation induced by geometrical features such as constrictions or expansions or obstructions by debris or rocks should also be considered to better represent the erosion problem in the system. The use of cross section data of the ravines would help verify the model estimates. Moreover, the model needs to involve the capability to simulate erosion in branching gully systems. Furthermore, the present data available for the gauged ravines is for the last one year only. Using data of longer period time, in the future the model can be calibrated and validated for the study area. Testing of the model in a more complex environment also presents a future challenge. 


\section{LIST OF REFERENCES}

Baffaut, C., Nearing, M. A., Ascough II, J. C., and Liu, B. (1997). "The WEPP Watershed Modell : II. Sensitivity Analysis And Discretization on Small Watersheds." Transaction of the ASAE, 4(4), 935-943.

Betts, H. D., and DeRose, R. C. (1999). "Digital elevation models as a tool for monitoring and measuring gully erosion." International Journal of Applied Earth Observation and Geoinformation, 1(2), 91-101.

Bull, L. J., and Kirkby, M. J. (1997). "Gully processes and modeling." Progress in Physical Geography 21(3), 354-374.

Chow, V. T. (1973). "Open-Channel Hydraulics." McGraw-Hill, Singapore, 680.

Crouch, R. J. (1990). "Erosion Processes and Rates for Gullies in Granitic Soils Bathurst, New-South-Wales, Australia." Earth Surf. Process. Landf., 15(2), 169-173.

Engstrom, D. R., J.E.Almendinger, and J.A.Wolin. (1997). "Historical changes in sediment and phosphorus loading to the Upper Mississippi River." In: Final Research report prepared for the Metropolitan Council Environmental Services, St. Croix Watershed Research Station, Science Museum of Minnesota,Marine on St. Croix,MN.

Gran, K. B., Belmont, P., Day, S., Jennings, C., Johnson, A., Parker, G., Perg, L., and Wilcock, P. R. (2008). "Geomorphic evolution of the Le Sueur River, Minnesota, and implications of current sediment loading."

Kelley, D. W., and Nater, E. A. (2000). "Historical sediment flux from three watersheds into Lake Pepin, Minnesota, USA." Journal of Environmental Quality, 29(2), 561-568.

Kirkby, M. J., and Bull, L. J. (2000). "Some factors controlling gully growth in finegrained sediments: a model applied in southeast Spain." CATENA, 40(2), 127146.

Martinez-Casanovas, J. A., Anton-Fernandez, C., and Ramos, M. C. (2003). "Sediment production in large gullies of the Mediterranean area (NE Spain) from highresolution digital elevation models and geographical information systems analysis." Earth Surf. Process. Landf., 28(5), 443-456. 
Merritt, W. S., Letcher, R. A., and Jakeman, A. J. (2003). "A review of erosion and sediment transport models." Environmental Modeling \& Software, 18(8-9), 761799.

Meyer-Peter, E., and Müller, R. (1948). "Formulas for bed-load transport." In: Proceedings of the 2nd Meeting of the International Association for Hydraulic Structures Research, Delft, Netherlands, 39-64.

Minnesota Pollution Control Agency, Department of Agriculture Minnesota, State University Minnesota, Water Resources Center Manko, and Environmental Services MetropolitanConcil. (2007). "Summary of Surface Water Quality Monitoring 2000 -2005." In: State of The Minnesota River, 20.

Moriasi, D. N., Arnold, J. G., Liew, M. W. V., Bingner, R. L., Harmel, R. D., and Veith, T. L. (2007). "Model Evaluation Guidelines for Systematic Quantification of Accuracy in Watershed Simulations." Transactions of the ASABE, 50(3), 885-900.

Nash, J. E., and Sutcliffe, J. V. (1970). "River flow forecasting through conceptual models part I -- A discussion of principles." Journal of Hydrology, 10(3), 282290.

Poesen, J., Nachtergaele, J., Verstraeten, G., and Valentin, C. (2003). "Gully erosion and environmental change: importance and research needs." CATENA, 50(2-4), 91133.

Sidorchuk, A. (1999). "Dynamic and static models of gully erosion." CATENA, 37(3-4), 401-414.

Simons, D. B., and Senturk, F. (1992). "The Universal Soil Loss Equation." In: Sediment Transport Technology water and Sediment Dynamics, Water Resources Publications. Littleton, Colorado, 496 -502.

Smith, D. D., and Wischmeier, W. H. (1957). "Factors affecting Sheet and Rill Erosion." Transactions of American Geophysical Union, 38, 889 - 896.

Soil Science Society of America. (2001). "Glossary of Soil Science Terms." Madison, WI.

Thomas, J. T., Iverson, N. R., Burkart, M. R., and Kramer, L. A. (2004). "Long-term growth of a valley-bottom gully, western Iowa." Earth SurfaceProcesses and Landforms, 29(8), 995-1009. 
Torri, D., and Borselli, L. (2003). "Equation for high-rate gully erosion." CATENA, 50(24), 449-467.

Valentin, C., Poesen, J., and Yong, L. (2005). "Gully erosion: Impacts, factors and control." CATENA, 63(2-3), 132-153.

Vandekerckhove, L., Muys, B., J. Poesen, Weerdt, B. D., and Coppe', N. (2001a). "A method for dendrochronological assessment of medium-term gully erosion rates." CATENA, 45(2), 123-161.

Vandekerckhove, L., Poesen, J., and Govers, G. (2003). "Medium-term gully headcut retreat rates in Southeast Spain determined from aerial photographs and ground measurements." CATENA, 50(2-4), 329-352.

Vandekerckhove, L., Poesen, J., Wijdenes, D. O., and Gyssels, G. (2001b). "Short-term bank gully retreat rates in Mediterranean environments." CATENA, 44(2), 133161.

Wischmeier, W. H., and Smith, D. D. (1978). "Predicting rainfall erosion losses - a guide to conservation planning. ." In: Agriculture Handbook No 532, U.S Department of Agriculture, ed.

Woodward, D. E. (1999). "Method to predict cropland ephemeral gully erosion." CATENA, 37(3-4), 393-399.

Wu, Y., and Cheng, H. (2005). "Monitoring of gully erosion on the Loess Plateau of China using a global positioning system." CATENA, 63(2-3), 154-166. 
APPENDICES 
APPENDIX A 


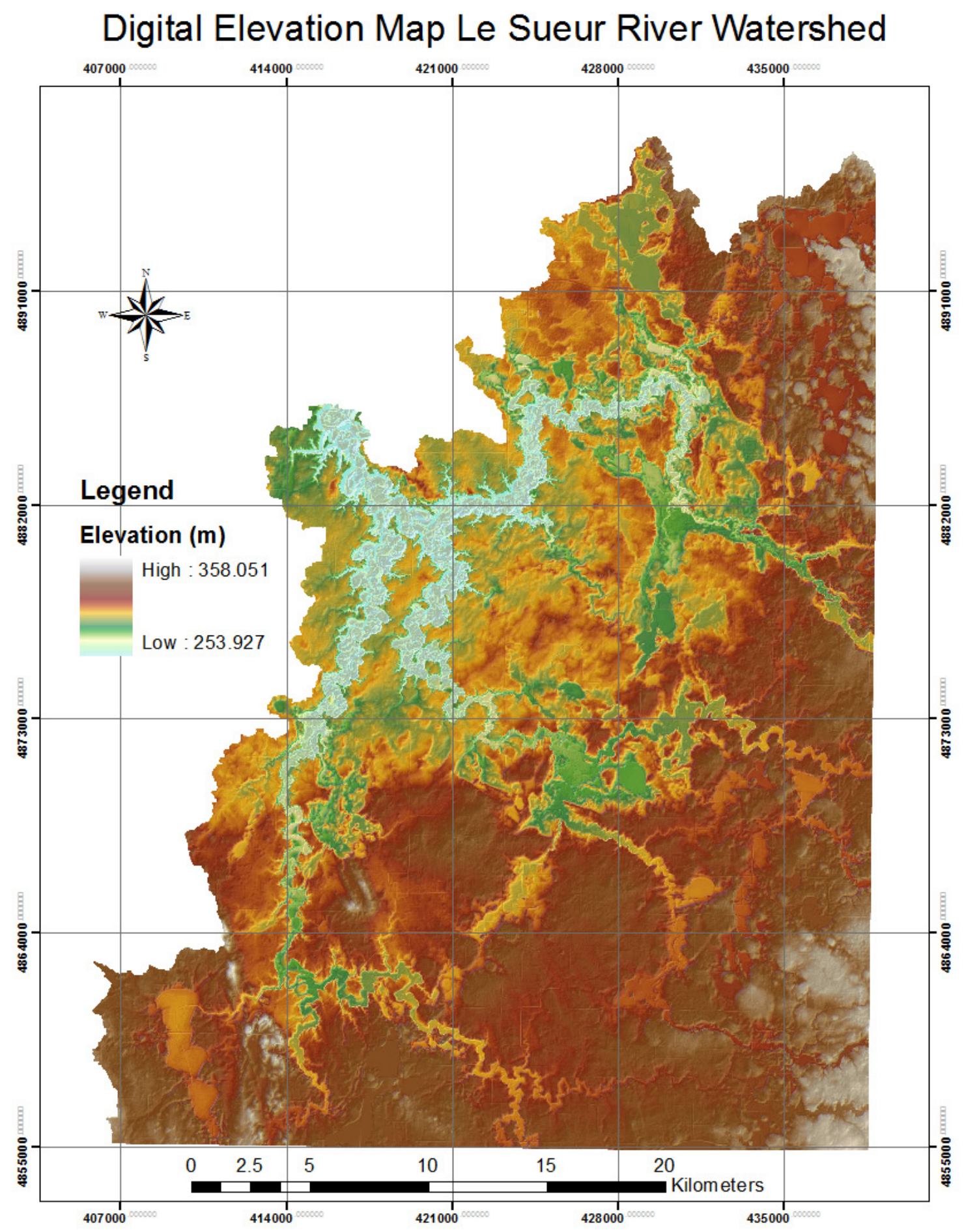

Figure A- 1. Digital Elevation Model of Le Sueur Watershed 


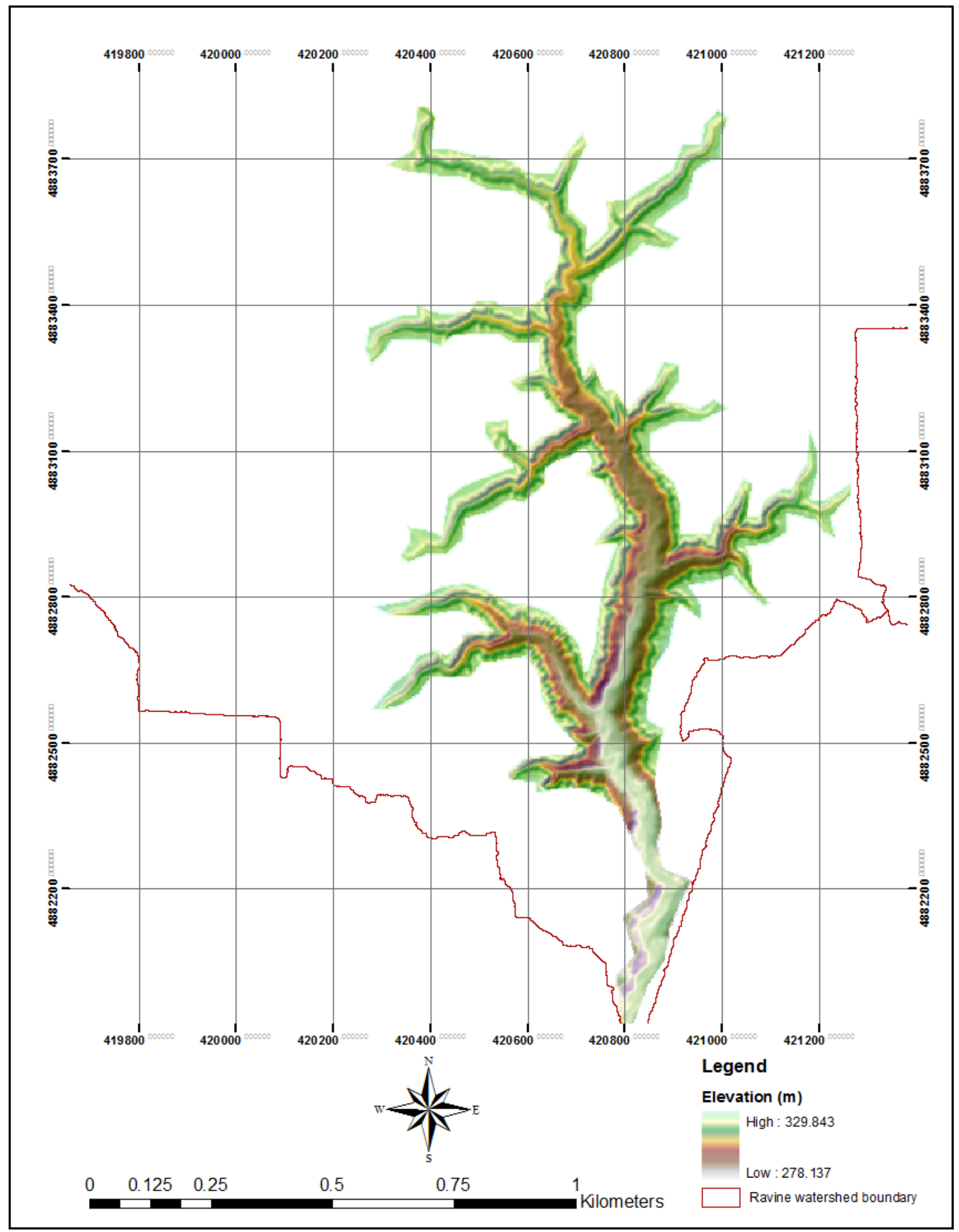

Figure A- 2. Elevation map (DEM) of Ravine CR-8 


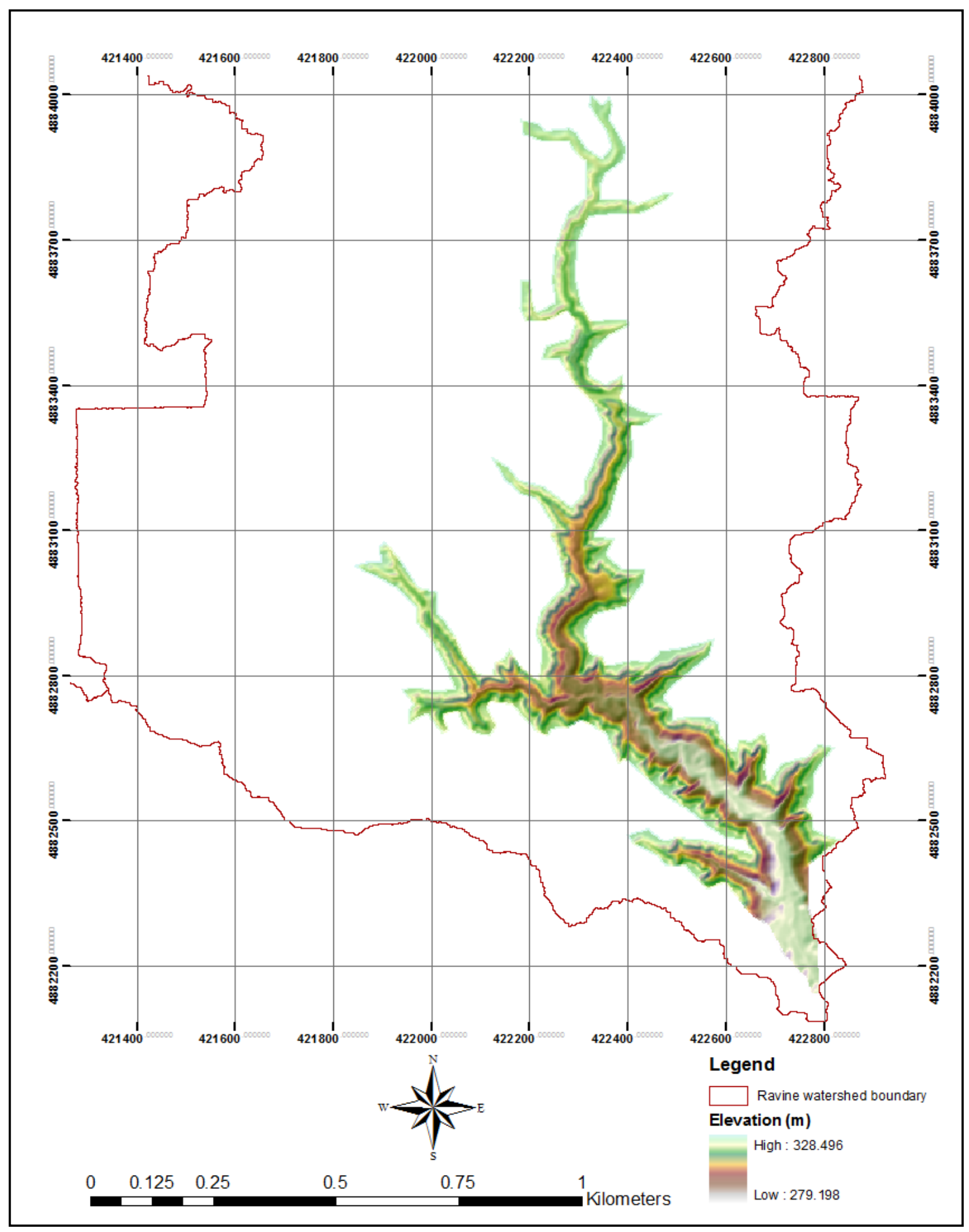

Figure A- 3. Elevation Map (DEM) of Ravine CR-90 


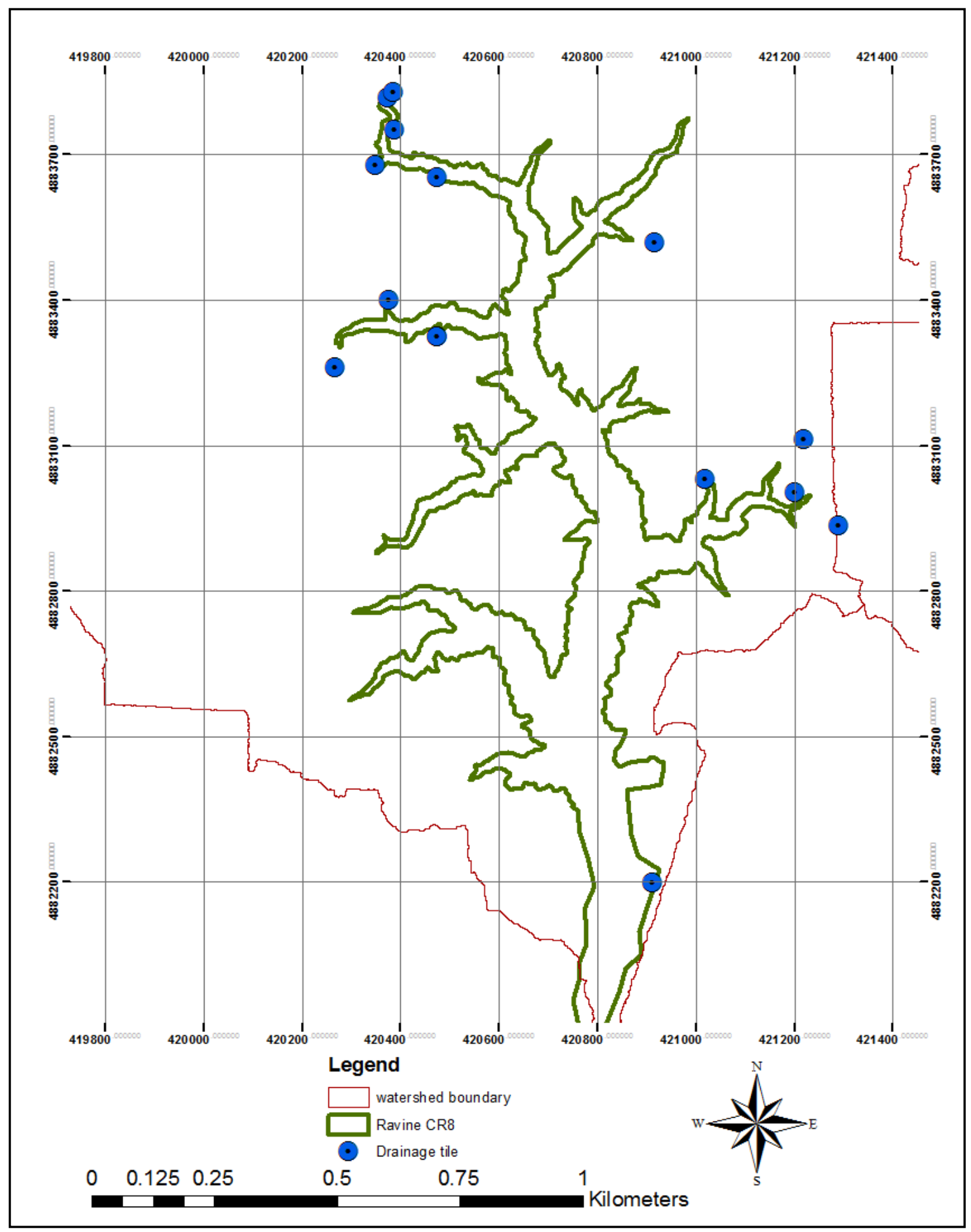

Figure A- 4. Drainage Tile Location in Ravine CR-8 


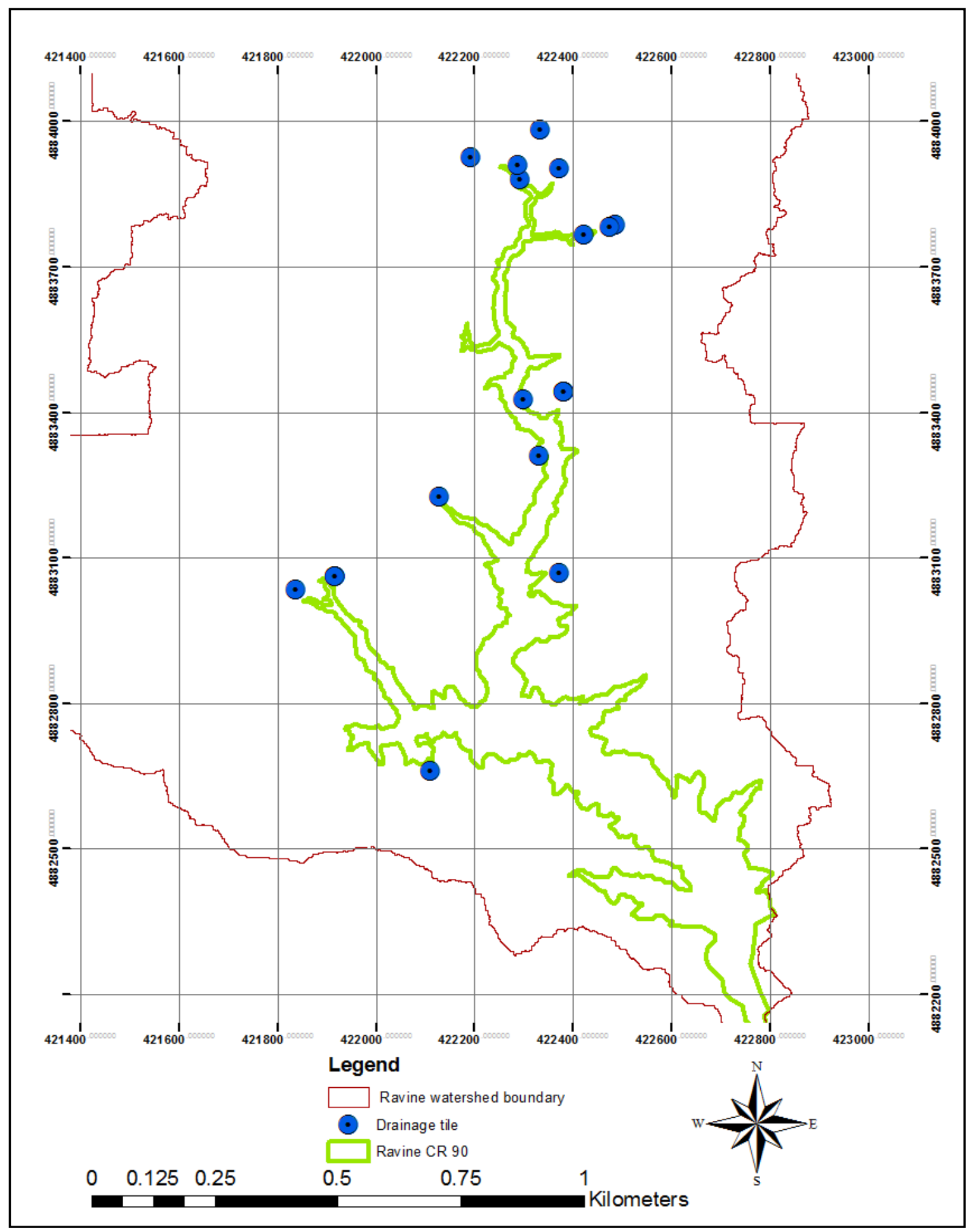

Figure A- 5. Drainage tile location on Ravine CR-90 


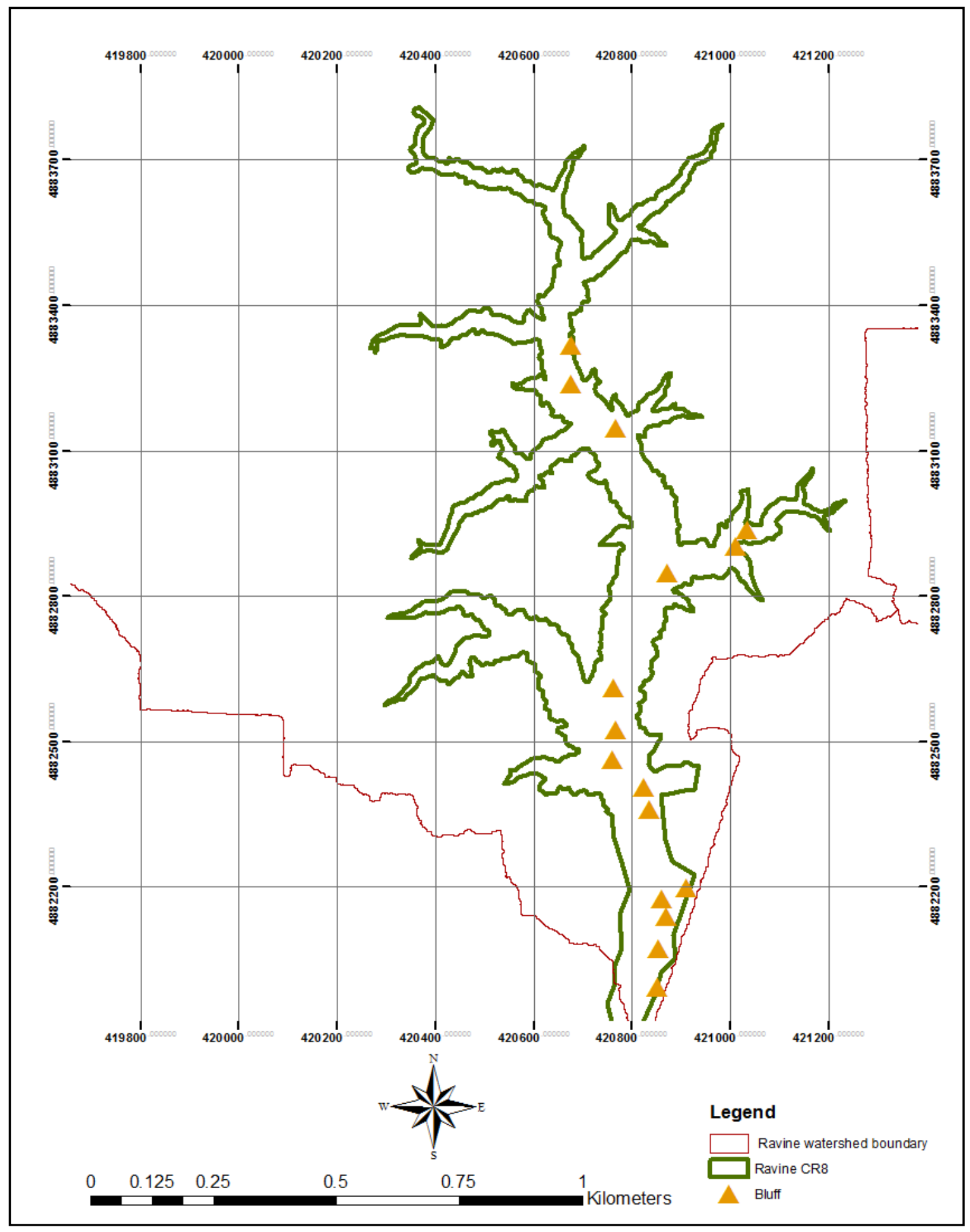

Figure A- 6. Bluffs in Ravine CR-8 


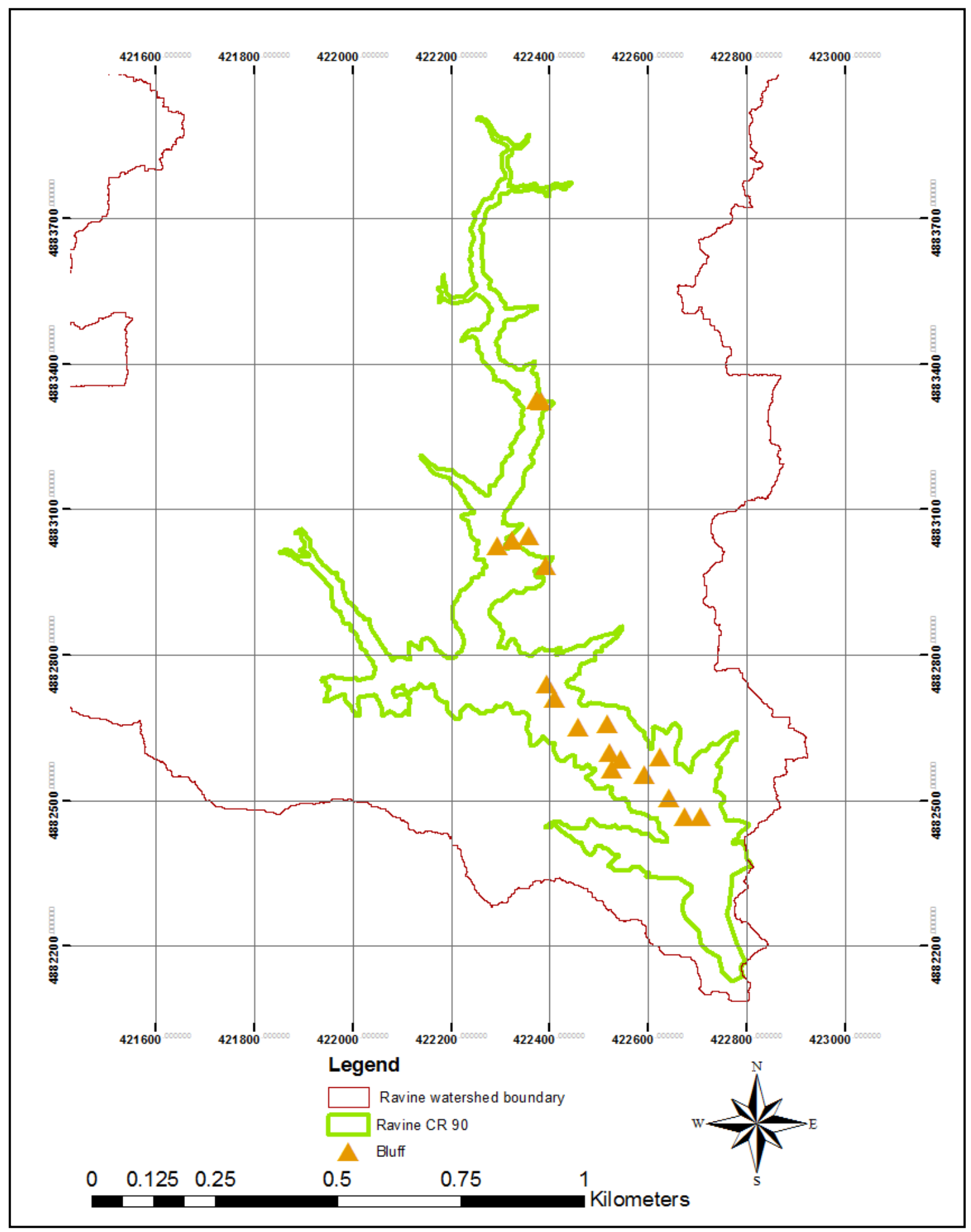

Figure A- 7. Bluffs in Ravine CR -90 


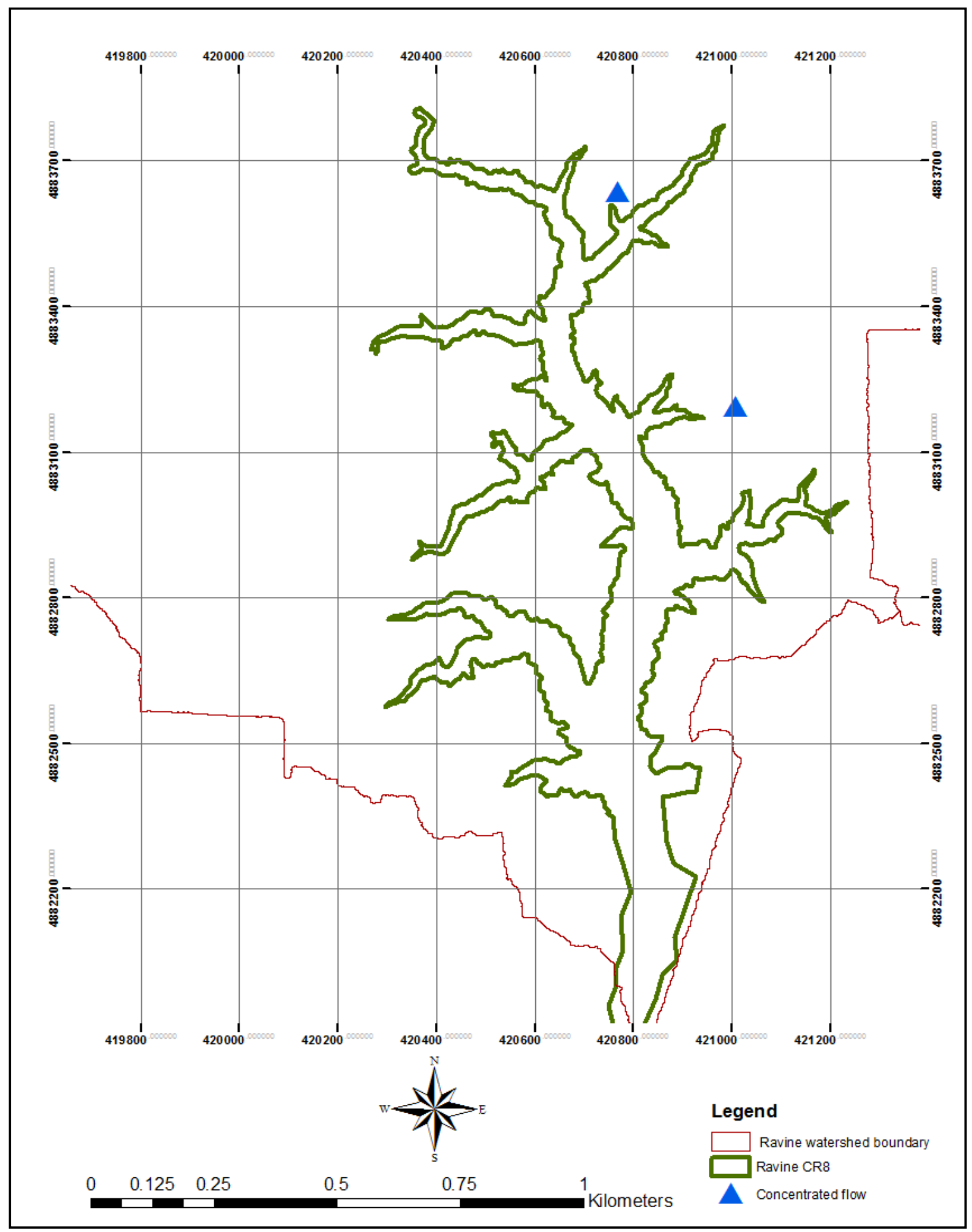

Figure A-8. Overland flow entry in Ravine CR-8 


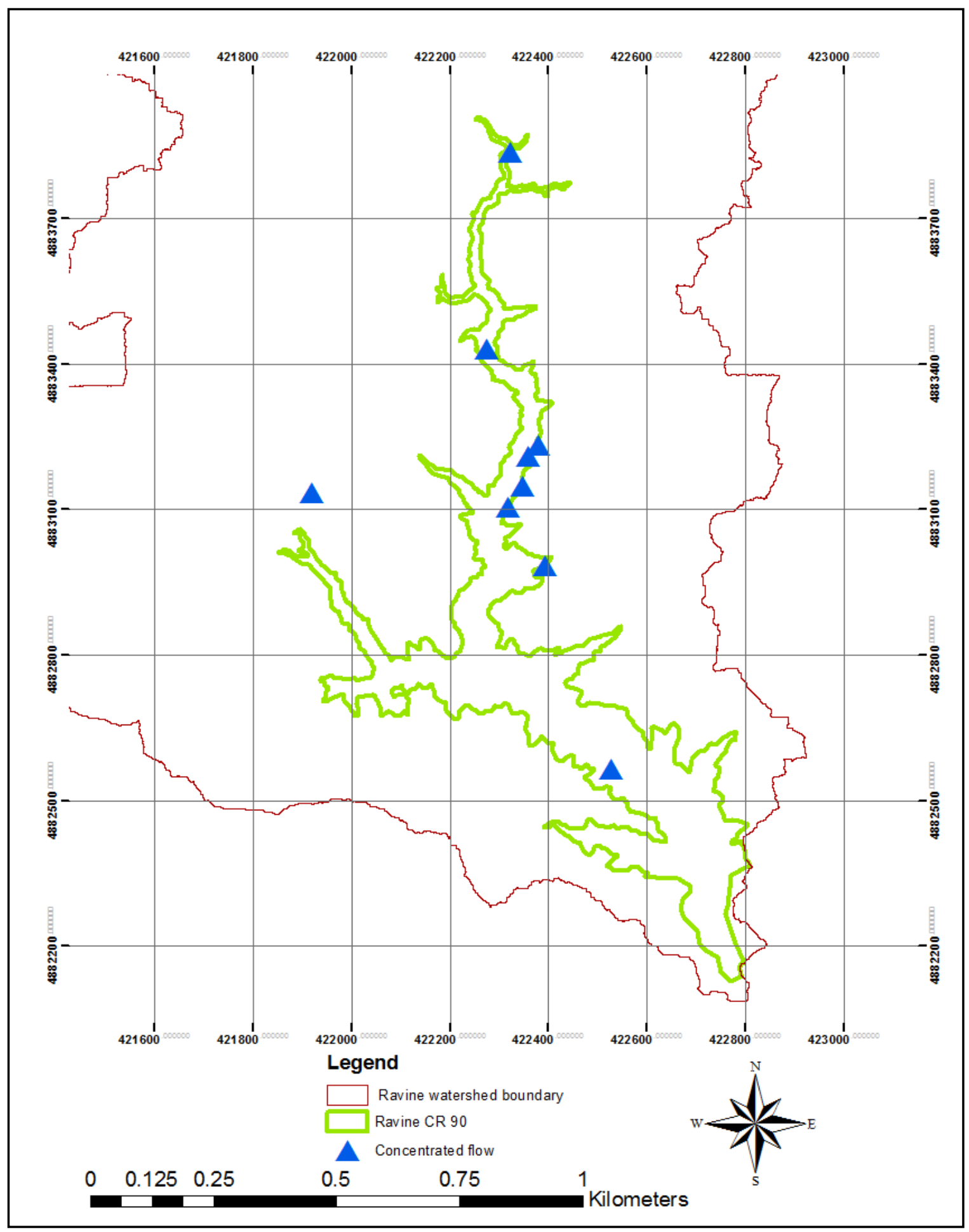

Figure A- 9. Concentrated flow entry points in ravine CR-90 


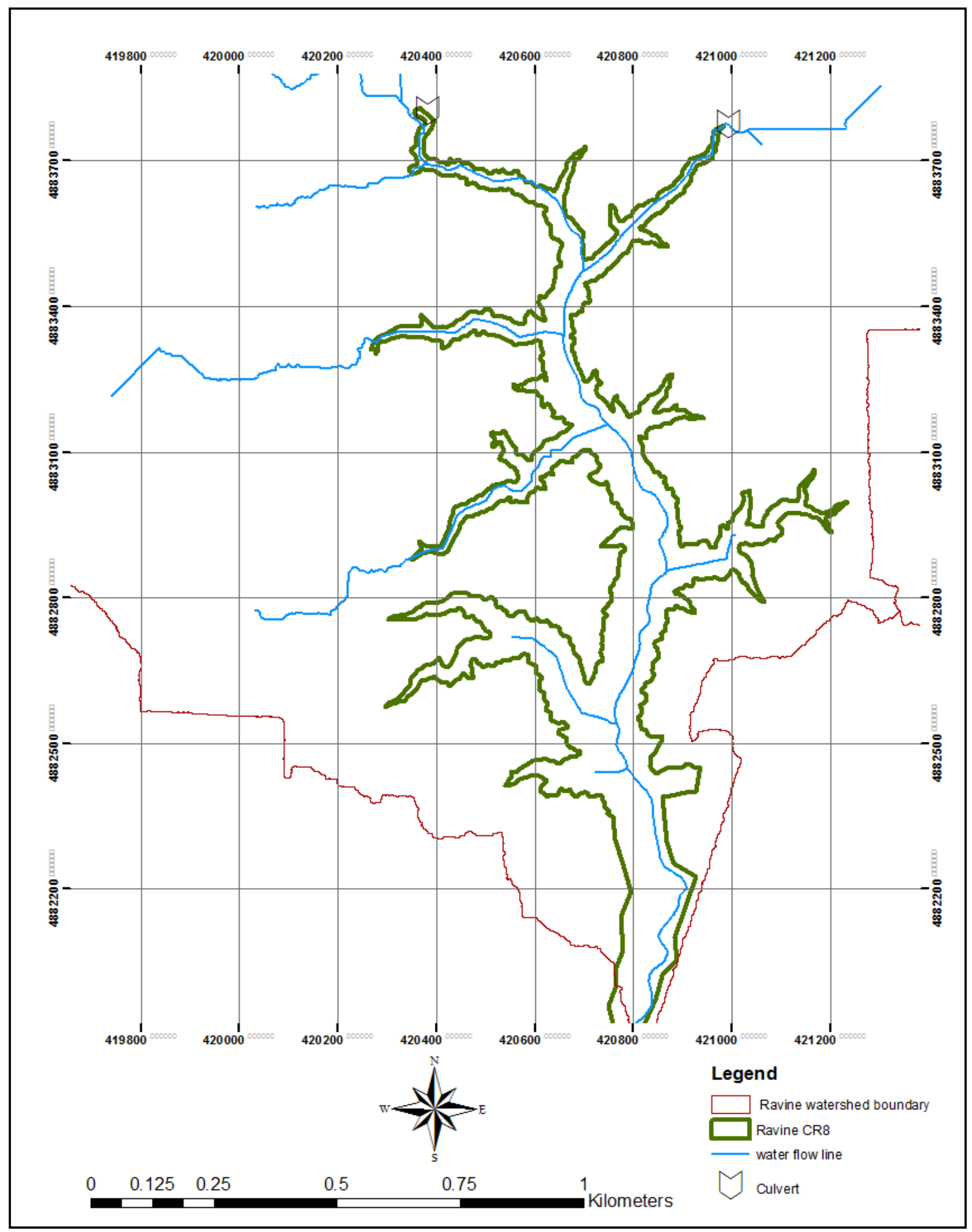

Figure A- 10. Drainage line and Culvert in Ravine CR-8 


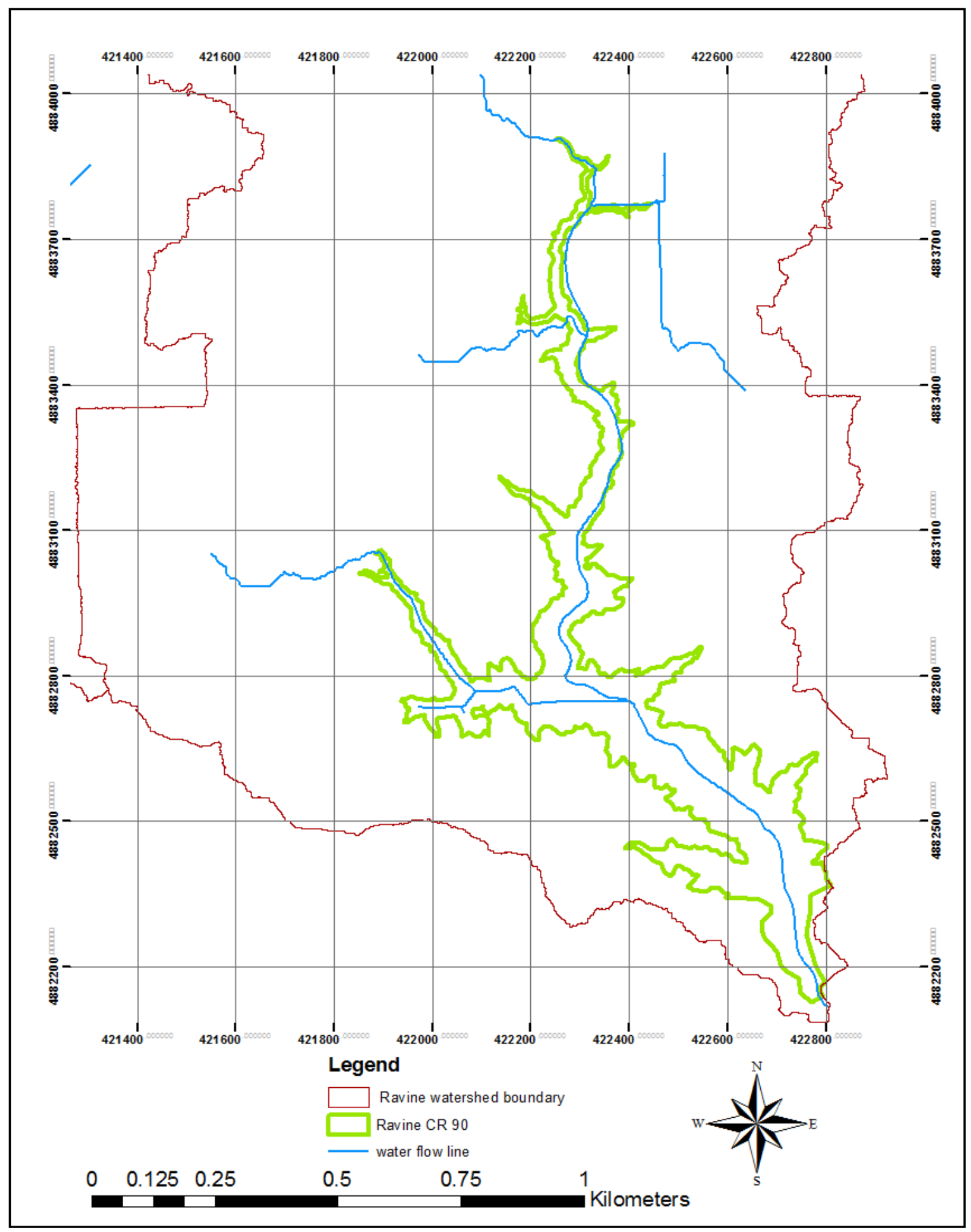

Figure A- 11. Drainage Line in Ravine CR-90 


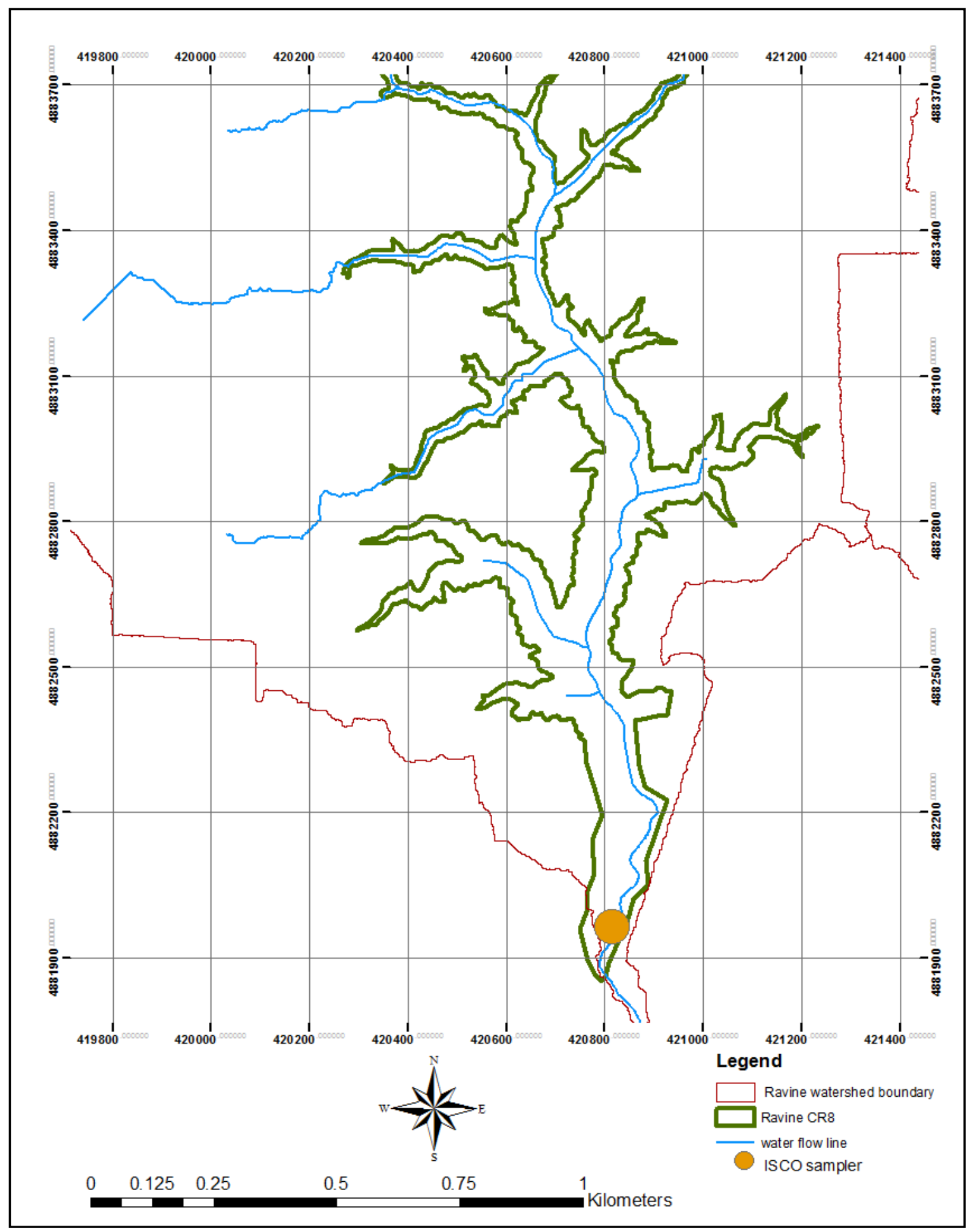

Figure A-12. Location of ISCO sampler in Ravine CR-90 


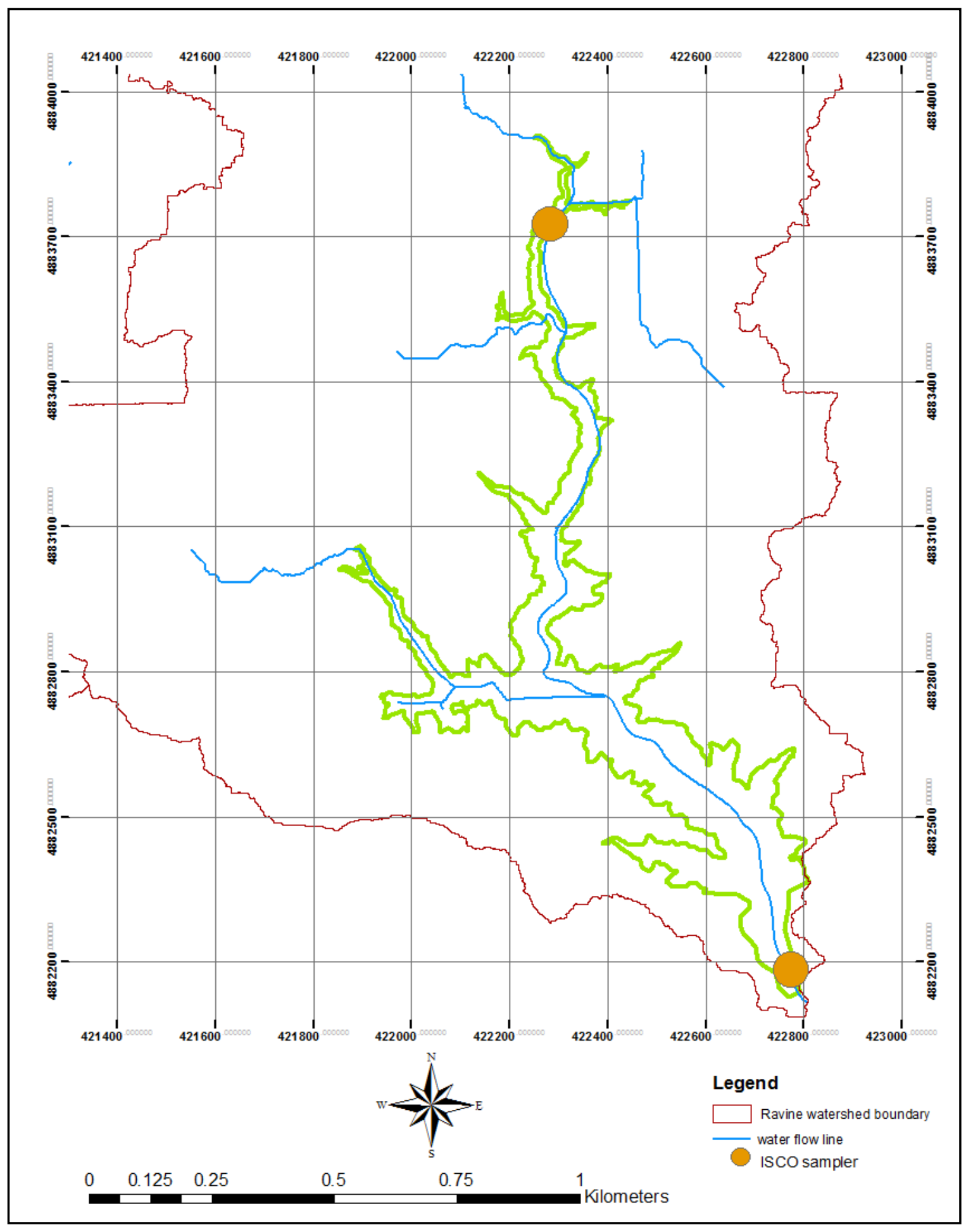

Figure A-13. Location of ISCO samplers in Ravine CR-90 
Table A-1. Tile drain data of ravines CR-8 and CR-90 collected during field survey, summer 2008

\begin{tabular}{|c|c|c|c|c|c|c|c|}
\hline $\begin{array}{c}\text { Ravine } \\
\text { Name }\end{array}$ & Feature Name & Date of Entry & $\mathbf{X}$ & $\mathbf{Y}$ & $\mathbf{Z}$ & $\begin{array}{c}\text { Diameter } \\
\text { (inches) }\end{array}$ & Remarks \\
\hline $\mathrm{CR}-8$ & Tile Drain & 7/22/08 9:20 & 420917 & 4883519 & 305 & 9 & Slope failure due to drain beacause there is no sigh of overlar \\
\hline CR-8 & Collector drain & $7 / 22 / 089: 20$ & 420388 & 4883751 & 342 & 6.5 & Walked up tributary from ravine to cron field. Initial incision ca \\
\hline CR-8 & Tile Drain & $7 / 22 / 089: 20$ & 420374 & 4883818 & 342 & 10 & Tile drain across from culvert with rock cover protection \\
\hline CR-8 & Tile Drain/ Field Intake & $7 / 22 / 089: 20$ & 420384 & 4883828 & 331 & 6 & Tile drain has low flow discharge. \\
\hline CR-8 & Tile Drain/Field Intake & $7 / 22 / 089: 20$ & 420349 & 4883678 & 302 & 6 & Tile drain has low flow discharge. \\
\hline CR-8 & Tile Drain & $7 / 22 / 089: 20$ & 420474 & 4883652 & 314 & 9 & Three tile drains but only two at the bottom are actively flowin \\
\hline CR-8 & Field Intake & $7 / 22 / 089: 20$ & 420376 & 4883401 & 313 & 5 & Drain is not actively flowing and it looks as if its not even conn \\
\hline CR-8 & Tile Drain & $7 / 22 / 089: 20$ & 420267 & 4883260 & 313 & 8 & Tile drain is at the head of the ravine \\
\hline CR-8 & Tile Drain & $7 / 22 / 089: 20$ & 420475 & 4883325 & 312 & 6 & There are two tiles. Tile drainage has low flow with slight failu \\
\hline CR-8 & Tile Drain & 7/22/08 9:20 & 420475 & 4883325 & 312 & 4.5 & Tile drainage has low flow with slight failure towards the end \\
\hline CR-8 & Collector drain & 7/23/08 10:00 & 420911 & 4882199 & 265 & 6 & \\
\hline CR-8 & Tile Drain & $7 / 10 / 08$ 10:00 & 421291 & 4882935 & 314 & 36 & Collector drain is coming in on the right side walking up strear \\
\hline CR-8 & Tile Drain & 7/10/08 10:00 & 421201 & 4883003 & 301 & & Culvert is next to road about 9 meters away from tip of ravine \\
\hline CR-8 & Tile Drain & 7/10/08 10:00 & 421220 & 4883112 & 320 & & Head of ravine is connected to culvert causing a deep pool at \\
\hline CR-8 & Tile Drain & 7/10/08 10:00 & 421018 & 4883030 & 316 & & Field intake at the head of tributary to ravine from agricultural \\
\hline CR-90 & Tile Drain & 6/9/08 11:00 & 422380 & 4883442 & -234 & 6 & Beginning of tributary to ravine has four tile drains coming in \\
\hline CR-90 & Tile Drain & 6/9/08 11:00 & 422380 & 4883442 & -234 & 11 & Beginning of tributary to ravine has four tile drains coming in \\
\hline CR-90 & Tile Drain & 6/9/08 11:00 & 422380 & 4883442 & -234 & 6 & Beginning of tributary to ravine has four tile drains coming in \\
\hline CR-90 & Tile Drain & 6/9/08 11:00 & 422380 & 4883442 & -234 & 9 & Beginning of tributary to ravine has four tile drains coming in \\
\hline CR-90 & Tile Drain & 6/9/08 11:00 & 422300 & 4883426 & 310 & 6 & Tile drain with medium flow and discharge has created a narr \\
\hline CR-90 & Intake & 6/10/08 9:10 & 422487 & 4883787 & -296 & 9.5 & Tile drain at other head of tributary stem. \\
\hline CR-90 & Tile Drain & 6/10/08 9:10 & 422421 & 4883765 & 299 & 6 & Tile drain with no flow right at a drastic change in slope and $g$ \\
\hline CR-90 & Tile Drain & 6/10/08 9:10 & 422293 & 4883879 & 300 & 6 & Old metal tile drain with low flow at the head of tributary to rav \\
\hline CR-90 & Tile Drain & 6/10/08 9:00 & 422287 & 4883909 & 302 & 7 & Old metal tile drain with low flow and signs of overland flow de \\
\hline CR-90 & Tile Drain & 6/10/08 9:00 & 422191 & 4883925 & 306 & 6.5 & White tile drain at the head of tributary. \\
\hline CR-90 & Tile Drain & 6/19/08 9:00 & 422332 & 4883309 & 316 & 10.5 & Cement drain with cement drain debris around stream bed. \\
\hline CR-90 & Tile Drain & 6/10/08 9:00 & 422373 & 4883903 & 303 & 6 & Tile drain with rock cover above drain leading from field. \\
\hline CR-90 & Tile Drain & 6/10/08 9:00 & 422334 & 4883983 & 310 & 12 & Old metal tile drain with high flow and rock cover at the botton \\
\hline CR-90 & Tile Drain & 6/19/08 9:00 & 422372 & 4883068 & 348 & 6 & Tile drain with medium flow coming out side slope of ravine is \\
\hline CR-90 & Tile Drain/ Field Intake & 6/19/08 9:00 & 422110 & 4882661 & 302 & 9 & Intake in soy field leading into ravine with one tile drain comin \\
\hline CR-90 & Tile Drain & 6/19/08 9:00 & 421917 & 4883062 & 306 & 14 & Intake from agricultural field is connected to culvert from wayp \\
\hline CR-90 & Tile Drain & 6/19/08 9:00 & 421917 & 4883062 & 306 & 12 & Intake from agricultural field is connected to culvert from wayk \\
\hline CR-90 & Tile Drain & 6/19/08 9:00 & 421917 & 4883062 & 306 & 10 & Intake from agricultural field is connected to culvert from wayk \\
\hline CR-90 & Tile Drain & 6/19/08 9:00 & 421837 & 4883035 & 312 & 8 & Intake from agricultural field has one tile drain coming in. Corr \\
\hline CR-90 & Tile Drain & 6/19/08 9:00 & 422128 & 4883226 & 332 & 27 & Walking up the ravine and the head is a 27 inched collector $d$ \\
\hline CR-90 & Tile Drain & 6/9/08 11:00 & & & & & First point of the day, tile drain and field intake at edge of agri \\
\hline CR-90 & Tile Drain & 6/10/08 9:00 & 422475 & 4883782 & -295 & 13 & Head of tributary to ravine with brick cover and woody debris. \\
\hline
\end{tabular}


Table A- 2. Bluff data in Ravines CR-8 and CR-90, collected during field survey, summer 2008

\begin{tabular}{|c|c|c|c|c|c|c|c|c|c|}
\hline $\begin{array}{c}\text { Ravine } \\
\text { Name }\end{array}$ & Feature & Date of Entry & $\mathbf{X}$ & $\mathbf{Y}$ & $\begin{array}{c}\mathrm{Z} \\
\text { (meters) }\end{array}$ & $\begin{array}{l}\text { Height } \\
\text { (meters) }\end{array}$ & $\begin{array}{c}\text { Width } \\
\text { (meters) }\end{array}$ & $\begin{array}{c}\text { surface } \\
\text { area }\end{array}$ & Remarks \\
\hline CR-8 & Bluff & 7/10/08 10:00 & 421035 & 4882937 & 305 & 5 & 9 & 45 & Bluff has sandy surface deposits and pebbles on its s \\
\hline CR-8 & Bluff & $7 / 10 / 08$ 10:00 & 421012 & 4882902 & 306 & 9 & & & Bluff valleyhas been filled with woody debris. \\
\hline CR-8 & Bluff & $7 / 10 / 0810: 00$ & 420873 & 4882848 & 306 & 4 & 15 & 60 & Bluff has sandy surface deposits. \\
\hline CR-8 & Bluff & $7 / 22 / 089: 20$ & 420676 & 4883317 & 295 & 4 & 10 & 40 & Bluff is across the stream from big fill terrace. Relief is \\
\hline CR-8 & Bluff & $7 / 22 / 089: 20$ & 420676 & 4883237 & 302 & 8 & 9 & 72 & Bluff has a high volume of vegetation. \\
\hline CR-8 & Bluff & $7 / 22 / 089: 20$ & 420767 & 4883146 & 284 & 12 & 15 & 180 & Huge bluff with visible stratigraphy levels. At 1 meter i \\
\hline CR-8 & Bluff & $7 / 23 / 0810: 00$ & 420777 & 4881902 & 222 & 3 & & & Starph terrace has 1 meter of gravel and about 2 met \\
\hline CR-8 & Bluff & $7 / 23 / 0810: 00$ & 420851 & 4881992 & 286 & 2.5 & & & Small bluff under terrace with river .5 meters of river $\mathrm{d}$ \\
\hline CR-8 & Bluff & $7 / 23 / 0810: 00$ & 420853 & 4882073 & 283 & 8 & 15 & 120 & Bluff with .5 meters of lake depoists and primary sand \\
\hline CR-8 & Bluff & $7 / 23 / 0810: 00$ & 420870 & 4882139 & 284 & 3 & 13 & 39 & Bluff is across the stream from big fill terrace. \\
\hline CR-8 & Bluff & $7 / 23 / 0810: 00$ & 420860 & 4882174 & 287 & 3.5 & 10 & 35 & Bluff with roots exposed on the overhang of its slope. \\
\hline CR-8 & Bluff & $7 / 23 / 0810: 00$ & 420911 & 4882199 & 265 & 3 & 6 & 18 & Small bluff with a low volume of vegetation. \\
\hline CR-8 & Bluff & $7 / 23 / 0810: 00$ & 420835 & 4882361 & 284 & 3 & & & Small bluff with a low volume of vegetation on the slop \\
\hline CR-8 & Bluff & $7 / 23 / 0810: 00$ & 420824 & 4882405 & 294 & 7 & 11 & 77 & Bluff has visible stratigtraphy levels. There is 1 meter \\
\hline CR-8 & Bluff & $7 / 23 / 08$ 10:00 & 420760 & 4882463 & 290 & 4 & 8 & 32 & Bluff has a visible lense of till on top of sandy deposits \\
\hline CR-8 & Bluff & $7 / 23 / 0810: 00$ & 420767 & 4882525 & 281 & 3 & & & Bluff with tree landsliding at the bottom laying across \\
\hline CR-8 & Bluff & $7 / 23 / 0810: 00$ & 420762 & 4882611 & 293 & 13 & 15 & 195 & Bluff has sandy deposits and vegetation cover over $\mathrm{m}$ \\
\hline CR-90 & Bluff & 6/10/08 9:00 & 422707 & 4882466 & 271 & 9 & & & Bluff is the first sited walking from the mouth. Cause \\
\hline CR-90 & Bluff & $6 / 16 / 0810: 47$ & 422676 & 4882466 & 296 & 7 & & & Second bluff from the mouth is 10 meters away from \\
\hline CR-90 & Bluff & $6 / 16 / 08$ 10:47 & 422644 & 4882506 & 263 & 12 & 20 & 240 & Bluff has sandy and gravel surface deposits with som \\
\hline CR-90 & Bluff & $6 / 16 / 08 \quad 10: 47$ & 422625 & 4882589 & 301 & 12 & & & Bluff within an active tributary (fallen trees, eroding, ve \\
\hline CR-90 & Bluff & $6 / 16 / 0810: 47$ & 422594 & 4882554 & 288 & 8 & 15 & 120 & Bluff is along path of stream after passing tributary wit \\
\hline CR-90 & Bluff & $6 / 16 / 08 \quad 10: 47$ & 422527 & 4882564 & 306 & 7 & 13 & 91 & Tributary from ravine. Intial flow channel is due to ove \\
\hline CR-90 & Bluff & $6 / 16 / 0810: 47$ & 422546 & 4882585 & 280 & 15 & 12 & 180 & The highest o have seen. Bluff has more vegetation a \\
\hline CR-90 & Bluff & $6 / 16 / 08$ 10:47 & 422523 & 4882600 & 283 & 10 & 12 & 120 & Bluff has very steep slope- 80 degree angle and veget \\
\hline CR-90 & Bluff & $6 / 16 / 0810: 47$ & 422518 & 4882659 & 272 & 8 & & & Bluff has recent landsliding, even snapped property lir \\
\hline CR-90 & Bluff & 6/19/08 9:00 & 422374 & 4883326 & 302 & 6 & 10 & 60 & Concaved valley has about a 60 degree angled slope. \\
\hline CR-90 & Bluff & 6/19/08 9:00 & 422294 & 4883026 & 324 & 8 & 6 & 48 & Bluff is eroding backwards and this is exemplified by \\
\hline CR-90 & Bluff & 6/19/08 9:00 & 422323 & 4883036 & 326 & 9 & & & Bluff has a low amount of vegetation at the bottom an \\
\hline CR-90 & Bluff & 6/19/08 9:00 & 422358 & 4883046 & 332 & 7 & & & Slightly vegetated bluff across the stream from a fill te \\
\hline CR-90 & Bluff & 6/19/08 9:00 & 422382 & 4883324 & 304 & 6 & & & Bluff with landsliding and bowl like structure. \\
\hline CR-90 & Bluff & 6/19/08 9:00 & 422394 & 4882740 & 296 & 4 & 18 & 72 & Bluff has a very steep slope-90 degree angle \\
\hline CR-90 & Bluff & 6/19/08 9:00 & 422411 & 4882710 & 299 & 6 & 15 & 90 & Bluff has a 70 degree angle slope \\
\hline
\end{tabular}

Table A- 3. Terrace data in Ravines CR-8 and CR-90, collected during field survey, summer 2008 


\begin{tabular}{|c|c|c|c|c|c|c|c|c|c|}
\hline $\begin{array}{l}\text { Ravine } \\
\text { Name }\end{array}$ & $\begin{array}{l}\text { Feature } \\
\text { Name }\end{array}$ & $\begin{array}{l}\text { Date of } \\
\text { Entry }\end{array}$ & $\mathbf{X}$ & $\mathbf{Y}$ & $\mathbf{Z}$ & Area $(\mathrm{m} 2)$ & $\begin{array}{c}\text { Depth } \\
(\mathrm{m})\end{array}$ & $\begin{array}{l}\text { Volume } \\
\text { (m3) }\end{array}$ & Notes \\
\hline CR-90 & Terrace & $6 / 9 / 08$ & 422297 & 4883412 & 307 & 178.61 & & 0.00 & \\
\hline CR-90 & Terrace & $6 / 9 / 08$ & 422285 & 4883450 & 310 & 723.80 & & 0.00 & Area assumed as elips, it's fill terace, walking Up from culvert \\
\hline CR-90 & Terrace & $6 / 9 / 08$ & 422298 & 4883462 & 300 & 259.17 & & 0.00 & $\begin{array}{l}\text { Area assumed as elips, it's fill terace.It's at the foot of two ravines, overland } \\
\text { flow at head, Extremely active }\end{array}$ \\
\hline CR-90 & Terrace & $6 / 10 / 08$ & 422301 & 4883479 & 303 & 36741.22 & & 0.00 & $\begin{array}{l}\text { Area assumed as elips,It's part of the previous terrace, Extremely active, } \\
\text { water flows on both sides }\end{array}$ \\
\hline CR-90 & Terrace & $6 / 16 / 08$ & 422754 & 4882224 & 272 & 81.75 & 0.70 & 57.23 & $\begin{array}{l}\text { Area assumed as Triangle, length of sides measured,It's part of the } \\
\text { previous terrace,Extremely active,water flows on both sides }\end{array}$ \\
\hline CR-90 & Terrace & $6 / 16 / 08$ & 422676 & 4882466 & 296 & 18.58 & 1.00 & 18.58 & $\begin{array}{l}\text { Area assumed as a regtangle, This is when walking upstream from the } \\
\text { mouth. Water looks a bit clear, not muddy, very narrow water way,Bluffs at } \\
\text { the sides are falling, extremely active }\end{array}$ \\
\hline CR-90 & Terrace & $6 / 16 / 08$ & 422307 & 4883056 & 328 & 7.75 & 0.40 & 3.10 & Area assumed as triangle, covered with vegetation and trees. \\
\hline CR-90 & Terrace & $6 / 16 / 08$ & 422323 & 4883036 & 326 & 7.80 & 0.40 & 3.12 & Area assumed as triangle, $9 \mathrm{mt}$ high bluff exists across \\
\hline CR-90 & Terrace & $6 / 19 / 08$ & 422393 & 4882985 & 337 & 53.32 & 0.40 & 21.33 & Three valley paths of overland flow with extreme landsliding and debris \\
\hline CR-90 & Terrace & $6 / 19 / 08$ & & & & & & & \\
\hline CR-90 & Terrace & $6 / 19 / 08$ & & & & & & & \\
\hline CR-8 & Terrace & $7 / 22 / 08$ & 420687 & 4883308 & 312 & 127.23 & 0.30 & 52.17 & these are two terraces, $7^{\star} 2$ rectangular and $9 \mathrm{~m}$ diamerter simcircle \\
\hline CR-8 & Terrace & $7 / 22 / 08$ & 420640 & 4883298 & 298 & 113.10 & 0.40 & 59.24 & \\
\hline CR-8 & Terrace & $7 / 22 / 08$ & 420658 & 4883253 & 302 & 32.00 & 1.50 & 62.00 & \\
\hline CR-8 & Terrace & $7 / 22 / 08$ & 420680 & 4883246 & 294 & 120.00 & 0.75 & 104.00 & \\
\hline CR-8 & Terrace & $7 / 22 / 08$ & 420698 & 4883209 & 281 & 720.00 & 1.00 & 734.00 & \\
\hline CR-8 & Terrace & $7 / 23 / 08$ & 420815 & 4881922 & 231 & 706.86 & & & \\
\hline CR-8 & Terrace & $7 / 23 / 08$ & 420852 & 4881956 & 239 & 224.00 & 1.00 & 224.00 & table top flat, little vegetation, stephany made tree coring \#1 \\
\hline CR-8 & Terrace & $7 / 23 / 08$ & 420853 & 4882073 & 283 & & 3.00 & 0.00 & \\
\hline CR-8 & Terrace & $7 / 23 / 08$ & 420881 & 4882165 & 267 & 376.99 & 0.30 & 113.10 & \\
\hline CR-8 & Terrace & $7 / 23 / 08$ & 420868 & 4882265 & 269 & 565.49 & 0.40 & 226.19 & Flat top \\
\hline CR-8 & Terrace & $7 / 23 / 08$ & 420868 & 4882277 & 277 & 60.00 & 0.30 & 18.00 & \\
\hline CR-8 & Terrace & $7 / 23 / 08$ & 420825 & 4882356 & 278 & 628.32 & 0.50 & 314.16 & lots of vegetation (tree) stephany's tree coring \#5 \\
\hline CR-8 & Terrace & $7 / 23 / 08$ & 420780 & 4882455 & 300 & 60.00 & 1.25 & 75.00 & \\
\hline CR-8 & Terrace & $7 / 23 / 08$ & & & & 120.00 & 1.50 & 180.00 & \\
\hline CR-8 & Terrace & $7 / 23 / 08$ & 420746 & 4882550 & 283 & 4095.00 & 1.00 & 4095.00 & \\
\hline
\end{tabular}

Table A- 4. Entry points of Overland flow in Ravines CR-8 and CR-90, collected during field survey, summer 2008 


\begin{tabular}{|c|c|c|c|c|c|c|}
\hline $\begin{array}{l}\text { Ravine } \\
\text { Name }\end{array}$ & Feature Name & $\begin{array}{l}\text { Date of } \\
\text { Entry }\end{array}$ & $\mathbf{x}$ & $\mathbf{Y}$ & $\mathbf{Z}$ & Remarks \\
\hline CR-90 & Overland Flow & $6 / 9 / 2008$ & 422273 & 4883431 & -309 & \\
\hline CR-90 & Overland Flow & $6 / 10 / 2008$ & 422321 & 4883838 & 300 & Overland flow has a dry path but very steep slopes, about a 70 degree \\
\hline CR-90 & Overland Flow & $6 / 16 / 2008$ & 422527 & 4882564 & 306 & $\begin{array}{l}\text { It has valleys in between on both sides with a channel of water flowing } \\
\text { between it down to the end where it meets the flow of the mainstem. At } \\
\text { my standpoint i was able to notice alot of vegetation on the walls of the } \\
\text { bluff and i was only able to see one side. }\end{array}$ \\
\hline CR-90 & Overland Flow & $6 / 19 / 2008$ & 422379 & 4883232 & 326 & $\begin{array}{l}\text { Overland flow has a narrow channel at the end of slope to stream. Very } \\
\text { active and wide at the beginning. The depth of incision is } 1 \text { meter and is } 14 \\
15 \text { meters long. } 1.5 \text { meters deep in the middle. }\end{array}$ \\
\hline CR-90 & Overland Flow & $6 / 19 / 2008$ & 422357 & 4883210 & 329 & Overland flow has a concaved slope. \\
\hline CR-90 & Overland Flow & $6 / 19 / 2008$ & 422346 & 4883148 & 330 & $\begin{array}{l}\text { Overland flow with farming machinery and other debris from uplands. } \\
\text { Slope is very wide and not that steep- } 60 \text { degree angle. }\end{array}$ \\
\hline CR-90 & Overland Flow & $6 / 19 / 2008$ & 422317 & 4883106 & 329 & $\begin{array}{l}\text { Overland flow has a narrow channel like path. } 70 \text { degree angle slope and } \\
\text { is about } 2.5 \text { meters deep. }\end{array}$ \\
\hline CR-90 & Overland Flow & $6 / 19 / 2008$ & 422393 & 4882985 & 337 & $\begin{array}{l}\text { Three valley paths of overland flow with extreme landsliding and debris } \\
\text { above an old fill terrace. Water paths are dry. Waypoint } 067 \text { was taken } \\
\text { inside right Bluff valley and Waypoint } 068 \text { was taken by overland flow on }\end{array}$ \\
\hline CR-90 & Overland Flow & $6 / 19 / 2008$ & 421918 & 4883134 & 309 & $\begin{array}{l}\text { Overland flow is at the head of the tributay to the ravine but a tile is also } \\
\text { coming in a few feet away. }\end{array}$ \\
\hline CR- 8 & Overland Flow & $7 / 22 / 2008$ & 420767 & 4883638 & 306 & Overland flow is the head of tributary from field. Corn crop. \\
\hline CR- 8 & Overland Flow & $7 / 22 / 2008$ & 421007 & 4883195 & 305 & Head of tributary has overland flow coming from the agricultural field. \\
\hline
\end{tabular}

Table A- 5. Location of Culverts in Ravines CR-8 and CR-90, collected during field survey, summer 2008 


\begin{tabular}{|l|l|l|c|c|c|l||}
\hline $\begin{array}{c}\text { Ravine } \\
\text { Name }\end{array}$ & $\begin{array}{c}\text { Feature } \\
\text { Name }\end{array}$ & Date of Entry & $\mathbf{X}$ & $\mathbf{Y}$ & $\mathbf{Z}$ & Remarks \\
\hline CR-8 & Culvert & $7 / 22 / 089: 20$ & 420993 & 4883777 & 261 & $\begin{array}{l}\text { Culvert is next to road about 9 meters away from tip of ravine. The } \\
\text { head of the ravine has a lot of rock cover. This is the left tributary } \\
\text { closer to the road ( highway 8) }\end{array}$ \\
\hline CR-8 & Culvert & $7 / 22 / 089: 20$ & 420382 & 4883803 & 339 & $\begin{array}{l}\text { Head of ravine is connected to culvert created plung pool at the } \\
\text { stream bed. }\end{array}$ \\
\hline
\end{tabular}

